\title{
Coronary microvascular and endothelial function regulation: Crossroads of psychoneuroendocrine immunitary signals and quantum physics [Part A]
}

\author{
Carlo Dal Lin, Anna Poretto, Marta Scodro, Martina Perazzolo Marra, Sabino Iliceto and Francesco Tona \\ Department of Cardiac, Thoracic and Vascular Sciences, Padua University School of Medicine, Via Giustiniani 2, 35100 Padua, Italy
}

\begin{abstract}
Nowadays the heart can be considered as a psycho-neuro-endocrine-immunitary structure that constantly interacts with other organs through a dynamic dialogue made of neurotpeptides, hormones and cytokines. The exploration of microvascular function is important as predictive tool and as prognosis of cardiovascular risk and progression of heart failure. This review describes the present knowledge on whether neurotramitters, hormones and cytokines influence microvascular/endothelial function and its genetic and epigenetic background. The review, describing the rich network of connections acting every moment of our lives linking endothelial function to the psychophysical environment, leads then to the description of an endothelial cell functioning, with the look of quantum physics. All this allows to describe some actual scientific methodological and epistemiological problems that remain to be resolved in order to fully understand endothelial function regulation, and future research, prevention and treatment directions. In the end, we describe the "Integrative Medicine" approach (and its beneficial influences on endothelial function regulation) that has emerged as a potential solution to the crisis in the healthcare system of western countries. It provides care that is patient-centered and healing-oriented, stressing the use of treatments originating from both conventional and alternative medicine.
\end{abstract}

\begin{abstract}
Part A]
In this first part we discuss the factors that regulate endothelial/microvascular coronary function. This represents the barometer of cardiovascular functioning and its regulation intervenes in almost all heart diseases. In particular, endothelial cells are affected by psycho-neurological, endocrine and immune stimuli that, influencing each other, constitute an integrated network (PNEI). This system responds to the environment and its organization is transgenerationally transmitted through epigenetic mechanisms.
\end{abstract}

\section{Introduction}

According to the 2010 Heart Disease and Stroke Statistics update of the American Heart Association, about 20 million persons in the United States have coronary heart disease (CHD), precisely 8.5 million with myocardial infarction and 10.2 million with angina pectoris [1]. The lifetime risk of developing CHD for men and women aged 40 years is respectively 50 percent and 30 percent. For those reaching 70 years, the lifetime risk is 35 percent in men and 24 percent in women [2]. Over 4 million annual deaths are due to cardiovascular disease according to a 2014 World Health Organization study, using data from 49 countries in Europe and northern Asia [3]. Mortality from CHD is expected to increase in developing countries (including China, India, sub-Saharan Africa, Latin America and the Middle East), from an estimated 9 million in 1990 to a projected 19 million by 2020 [4].

Hypertension, dyslipidemia, diabetes mellitus and cigarette smoking represent well established risk factors for cardiovascular disease (CVD), but understanding how other factors, such as stress [5], contribute to this burden is essential in order to develop new strategies to combat and/or prevent it.

An important indication is offered by the study and the understanding of cardiac microvascular function and the factors that regulate it.
In order to understand the logic of the factors that regulate endothelial function we will have to do an overview of many concepts that do not strictly belong, yet for the moment, to the "world of cardiology". Unfortunately, the fragmentation and specialization of knowledge prevents sometimes a vision that would allow to understand the phenomena that we observe in daily clinical practice. In this review we will try to make a journey to discover the main factors regulating the coronary microcirculation and endothelial function in general, deeper and deeper, reaching the structure of matter. A path that will lead us then again to the surface to suggest new avenues of research and treatment of cardiovascular diseases on the basis of the connections drawn. In this perspective we will present some difficulties in the Scientific Method related to the correct observation of biological

Correspondence to: Carlo Dal Lin, MD, Department of Cardiac, Thoracic and Vascular Sciences, Padua University School of Medicine, Via Giustiniani 2, 35100 Padua, Italy, Tel: +39-049 8218642, Fax: +39-049 8211802; E-mail: carlodallin@libero.it

Key words: endothelial function, coronary microcirculation, coronary flow reserve, cardiovascular disease, psychoneuroendocrineimmunology, epigenetics, stress, allostatic load, integrative medicine, complementary and alternative medicine

Received: August 28, 2015; Accepted: September 18, 2015; Published: September 24, 2015 
phenomena from the point of view of the human network connections, that can greatly affect the clinical work. Finally, we will present several examples of what can be done to modulate endothelial function for the prevention of the cardiovascular burden. The paper is focused on the main topic of the regulation of endothelial function as a key to understanding several cardiovascular disorders in order to be able to prevent their onset or severity. From this point of view we won't go into the details of individual molecular actions of all the presented actors (to this end, please consult the corresponding bibliography).

\section{Coronary flow physiology, coronary microvascular function and coronary flow reserve}

The myocardium is a strictly aerobic and oxygen-dependent tissue. $40 \%$ of the myocellular volume is occupied by mitochondria and their work is based on the assumption of free fatty acids, glucose or lactate [6]. The myocardial oxygen needs, or "oxygen consumption", is an accurate indicator of overall cardiac metabolism and depends on: heart rate, contractility and parietal tension (in turn dependent on the endoventricular pressure, the mean radius of the cavity and the wall thickness). The heart receives blood through the coronary circulation for $70 \%$ of its needs during the diastolic phase and for $30 \%$ in systole. Increasing the heart rate (greater energy demand) the duration of diastole decreases but the contribution of myocardial oxygen and energy substrates is ensured by the increased speed of coronary blood flow (up to 5 times greater) and the coronary vasodilation induced by adenosine releasing. Increasing the metabolic demands of the heart, adenosine (as a paracrine agent) induces vasodilation especially at the level of the coronary resistance vessels, which together form the microcirculation [7]. In basal conditions the heart consumes about 6.5$10 \mathrm{ml} / \mathrm{min} / 100 \mathrm{~g}$ tissue of oxygen and such an expenditure serves in $3-5 \%$ for the electrical activity, in $20 \%$ for the maintenance of cellular integrity, in $72-75 \%$ for contractile activity [8]. Given the high baseline myocardial oxygen extraction (about $70 \%$ ), the only compensation mechanism in case of increased oxygen requirements is represented by a proportional increase in the coronary flow, determined by a coronary vasodilation of the arteriolar district (resistance vessels) [9]. The maximum capacity of vasodilation secondary to a metabolic stimulus is defined Coronary Flow Reserve (CFR).

The ability to maintain the coronary flow relatively constant despite changes in perfusion pressure is defined "coronary autoregulation". Through this mechanism, decreases in perfusion pressure are compensated by decreases of the resistance, conversely increases of perfusion pressure are offset by increments of resistance; so that the flow remains constant [10]. The phenomenon of self-regulation, based on a multiplicity of mechanisms, hereinafter analyzed, is predominant in the microcirculation, in such a way as to have the greatest possible impact on coronary resistances [11].

As depicted in Figure 1, the coronary arterial system can be schematically divided into three compartments, each characterized by different structure and function. The first compartment is represented by proximal epicardial arteries with a vessel diameter ranging from $500 \mu \mathrm{m}$ up to $2-5 \mathrm{~mm}$. The epicardial arteries have a main capacitance function and offer only $10 \%$ of the resistance to coronary flow. The intermediate compartment is represented by prearteriole, the diameter of which ranges approximately between $100 \mu \mathrm{m}$ and $500 \mu \mathrm{m}$. Their function is to maintain the pressure distal to the origin of the arterioles within a certain range in the case of coronary perfusion pressure changing or a change in coronary flow. They are responsible for $25 \%$ of the total coronary resistance. The distal compartment is represented by arterioles, with a diameter of less than $100 \mu \mathrm{m}$, offering $55 \%$ of the total resistance to coronary flow. Together, prearterioles and arterioles offer the most resistances to the coronary flow and go to constitute the so-called "coronary microcirculation"[12]. In rest conditions, the coronary perfusion pressure is maintained along the epicardial arteries, then slowly fall along prearterioles and finally take a quick descent into the most distal compartment, i.e., within the microcirculation. When there is a change in coronary flow, the epicardial arteries and proximal arterioles have an inherent tendency to maintain a certain level of shearstress through endothelium-dependent vasodilation. When there is an increase in aortic pressure, the distal prearterioles undergo myogenic vasoconstriction in order to maintain a constant pressure at the origin of the arterioles, the most distal compartment. The latter plays a key role in the metabolic regulation of coronary flow. The arterioles, in fact, have a high resting tone and dilate in response to the release of the metabolites by the myocardium when there is an increase in oxygen consumption. Following this expansion, both the resistances along the coronary arterial system, both the pressure in the distal prearterioles decrease. Moreover, the dilatation of pre-distal arterioles and arterioles induces an increase of the shear-stress which in turn determines a flowdependent vasodilatation in proximal prearterioles and in epicardial capacity arteries [13].

The coronary circulation is regulated by four main factors (Figure 1): 1) anatomical (left ventricular wall thickness and the presence of collateral circulation), 2) mechanical (systemic flow, vascular resistance, systolic compression, myogenic reflection and blood viscosity or hemolysis and platelet aggregation), 3) neuro-immune (through alpha and beta2 receptors, vagal action) and 4) endocrine-metabolic ( $\mathrm{pO} 2, \mathrm{pH}, \mathrm{K}+$, adenosine, prostaglandins, tromboxane, hyperlipemia and nitric oxide (NO)) [13]. Among the anatomical factors we must remember that the coronary vessels are distributed in myocardial in a fractal way [14]. We can distinguish epicardial conductance vessels (they are in the surface and have a large caliber) and resistance vessels represented by arterioles, by intramyocardial vessels and capillaries [15]. The coronary resistance are regulated precisely by extrinsic factors (compression by the ventricular muscle) and intrinsic factors (such as neuro-hormonal, metabolic and myogenic factors) [16]. Coronary flow takes places especially in diastole because in systole intramural branches are virtually occluded by ventricular contraction. It follows that the tachycardia predisposes to the development of ischemia, as it shortens the diastolic time. Subendocardial layers are generally more exposed to ischemia mainly because more exposed to intracavitary pressure and tributaries of a terminal circulation.

The increased metabolic demand of the myocardium determines the hydrolysis of ATP and the resulting release of adenosine in the interstitium [17]. Adenosine induces vasodilation (counteracting the input of the calcium ion within the smooth muscle cells), especially at the level of resistance vessels, with a consequent increase in the coronary flow proportional to the increase of metabolic demands[8]. Other factors such as prostaglandins, hydrogen ions, potassium ions, the carbon dioxide and nitric oxide, are produced locally with vasodilating action [18].

The coronary arteries are innervated by the autonomic nervous system (the sympathetic system, through the action of noradrenaline on alpha-receptors, causes vasoconstriction, while acetylcholine, amine of vagal-parasympathetic system, causes vasodilatation) which ensures the normal vascular tone. It should be emphasized that the metabolic 


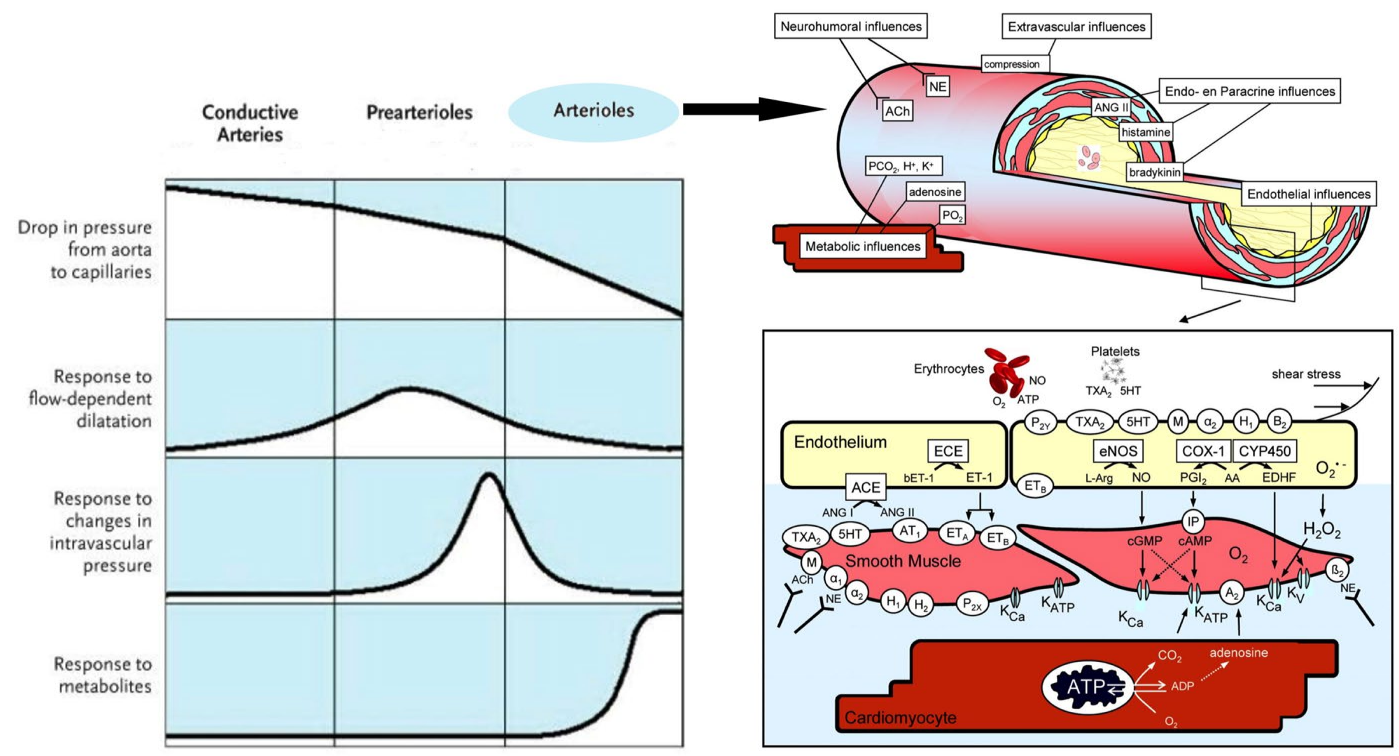

Figure 1. Functional anatomy of the coronary circulation (modified from [6,443]). Schematic drawing of the coronary flow regulation in the three compartements of the coronary arterial system. In particular is depicted a coronary arteriole and the various influences that the determine "microcirculatory function".

In the prearterioles and in the arterioles is present a endothelium-dependent vasoreactivity that transforms stimuli related to the flow in vasomotor responses. Vasodilation induced flow (FID, Flow-Induced vasodilatation) is an important physiologic mechanism which aims to adjust the coronary tone. The FID has been demonstrated in many different species, and thus is not only present in the human, although it varies the endothelial factor that mediates this response. The principal molecules responsible of this mechanism are nitric oxide (NO), prostacyclins (PGI2) and the EDHF (endothelium-derived hyperpolarizing factor) [444]. The increase of the shear stress on endothelial cells, due to an increase of the speed flow, results in a stimulation of endothelial nitric oxide synthase (eNOS) and the resulting release of NO, which determines the relaxation of smooth muscle cells. So, increasing the flow, vasodilation occurs maintaining constant intra-coronary pressure [10]. The release of NO and EDRF (endothelium-derived relaxing factor) can be also consequent to a stimulation of the endothelial cells of the vessels with larger caliber by many factors such as neuronal noradrenaline, adrenaline and acetylcholine. As explained in the main text, coronary microvascular function depends on four main factors. 1)neurological control: sympathetic and parasympathetic (vagal) systems innervate the coronary resistance vessels, changing their tone through a direct action on vascular smooth muscle cells (VSMC), or by stimulating endothelial NO releasing [445]. Both endothelial cells and VSMC express adrenergic receptors. For example, during stress or exercise, the release of norepinephrine from sympathetic nerve endings in the coronary vessels and the release of catecholamines from the adrenal glands cause a constriction of VSMC mediated by $\alpha$-adrenergic receptors that normally was offset by the release of vasodilatory substances (mainly NO) from endothelial cells. This interaction between the forces that cause vasoconstriction (mainly dependent on VSMC) and vasodilation (mainly based on the endothelium) adapts the diameter of the vessel on the flow, optimizing the resistences [10]. The effects of sympathetic system are complex and are connected to the activation of both $\beta 1$ and $\beta 2$ receptors (which mediate small arterioles vasodilatation) and $\alpha 1$ receptors (which determine pre-arteriolar vasoconstriction) [10]. The latter is necessary to optimize the coronary flow during exercise or stress conditions, making pre-arteriolar vessels less vulnerable to the compressive forces and tachicardia [446]. The parasympathetic action, mediated by acetylcholine, results in two simultaneous and opposite effects: the vasoconstriction of epicardial vessels and the release of vasodilating endothelial factors. 2) Myogenic control: the VSMC possess stretch receptors that are able to sense changes in intraluminal pressure. When it increases, vasoconstriction occurs and, on the contrary, when the pressure decreases, there is a vasodilatation. 3) Metabolic control: despite the increase in knowledge in this field, there is still no full consensus about the specific mediators of metabolic coronary vasodilation. The resistance in the coronary microcirculation is determined by integration of physical factors (eg. pressure and flow), vasodilating molecules (adenosine, $\mathrm{pO} 2$ and $\mathrm{H}+$ ), and neuro-humoral factors. All these elements and mechanisms contribute to forming muscle tone of vascular smooth muscle, which could eventually be controlled by opening and closing the ATP-sensitive potassium channels (KATP) [445]. It is thought that metabolic control is the most important mechanism by which increases in metabolic activity and oxygen consumption result in increases in coronary flow. The accumulation of vasoactive peptides may be subsequent to an increased metabolism, but also to a reduced perfusion pressure and the consequent reduced wash-out [11]. There is considerable redundancy in the mechanisms of local control of coronary flow; accordingly, eliminating a single mechanism in experimental conditions or in early pathological conditions, this does not necessarily affect the coronary flow balance at normal pressures or at rest. However, the lack of an important vasomotor mechanism can be discovered through cardiac stress tests, evaluating the flow regulation under reduced perfusion pressures distally to a coronary stenosis at rest or during exercise [445]. Interaction of microvascular control mechanisms:the control mechanisms described above interact with each other in order to increase blood flow and to ensure the oxygen supply in response to the increased demands of the myocardium. For example, a sudden increase in oxygen consumption in the course of stress or physical exercise increases the production of metabolites which mediate vasodilation of small caliber arterioles and, therefore, decreases the pressure upstream. The decreased pressure causes the medium caliber arterial myogenic vasodilation. The result is the decline in downstream resistance which increases flow in small arteries and those of great caliber upstream. This increased flow results in a endothelium-dependent vasodilation. This upstream vasodilation allows the transmission of the pressure in the downstream segments counteracting myogenic vasodilation. Furthermore, the increase of the flow allows the wash-out of the vasoactive metabolites, attenuating the metabolic vasodilation [11]. PO2, oxygen tension; TxA2, thromboxane A2 (receptor); 5HT, serotonin or 5-hydroxytryptamine (receptor); P2X and P2Y, purinergic receptor subtypes $2 \mathrm{X}$ and $2 \mathrm{Y}$ that mediate ATP-induced vasoconstriction and vasodilation, respectively; $\mathrm{ACh}$, acetylcholine; $\mathrm{M}$, muscarinic receptor; $\mathrm{H1}$ and H2, histamine receptors type 1 and 2; B2, bradykinin receptor subtype 2; ANG I and ANG II, angiotensin I and II; AT1, angiotensin II receptor subtype 1; ET, endothelin; ETA and ETB , endothelin receptor subtypes A and B; A2, adenosine receptor subtype 2; B2, B2-adrenergic receptor; $\alpha 1$ and $\alpha 2$, -adrenergic receptors; NO, nitric oxide; eNOS, endothelial NO synthase; PGI2, prostacyclin; IP, prostacyclin receptor; COX-1, cyclooxygenase-1; EDHF, endothelium-derived hyperpolarizing factor; CYP450, cytochrome P450 2C9; KCa, calcium-sensitive K+ channel; KATP, ATP-sensitive K+ channel; KV , voltage-sensitive K+ channel; AA, arachidonic acid; L-Arg, L-arginine; O--, 2 superoxide. Receptors, enzymes, and channels are indicated by an oval or rectangle, respectively.

factors are dominant on the nervous ones [19]. The stimulation of the stellate ganglion (sympathetic station) induces vasodilation (mediated by beta receptors), but at the same time increases the heart rate and muscle contractility [16]. On the other hand, beta-receptors blockade determines the appearance of alpha mediated effects (vasoconstriction) $[16]$.
A condition of myocardial ischemia is established by a mismatch between demand (oxygen consumption increased) and supply of oxygen and nutrients through the coronary flow. The most obvious case is the presence of an atherosclerotic stenosis of an epicardial branch that determines a downstream pressure drop proportional to the reduction of vasal caliber. The pressure gradient created stimulates 
the dilation of resistance vessels, in order to maintain adequate flow in basal conditions (in this situation, the coronary tree undertakes its reserve to maintain a proper metabolic balance). In case of increase of metabolic demands the circle is no longer able to cope with the demands with onset of ischemia. This mechanism can occur even in the absence of angiographically critical epicardial atherosclerotic lesions or even free of epicardial coronary lesions [20]. This is the case of the so called microcirculatory dysfunction, at the base of anginal symptoms with release of troponin and myocardial damage typical of many cardiac, endocrine, psycho-neurological and immunitary conditions, as we will see.

The discovery of $\mathrm{NO}$ as a crucial endothelium-derived molecule for vascular relaxation and the recognition of the endothelium as more than a passive interface between blood and the vessel wall, led to substantial progress in the field of vascular research [21]. The integrity of the endothelial cells (ECs) is critical for endothelial homeostatic responses. ECs are in a strategic anatomic position between the circulating blood and the vessel wall and regulate vascular function and structure releasing a variety of relaxing and contracting factors [22], by responding to mechanical forces and neurohormonal mediators. The endotheliumderived relaxing factors(EDRFs) (such as NO, prostacyclin and a still elusive factor that hyperpolarize vascular myocytes by opening voltage channels [23]), can also inhibit platelet adhesion and aggregation, leukocyte adhesion and migration and the proliferation of smooth muscle vascular cells [24]. Moreover, ECs produce vasoconstrictors such as angiotensin II, endothelin-1 (ET-1) and prostaglandin H2 (PGH2) that act also as growth promoters [24]. In normal ECs, NO is constitutively produced by endothelial-NO synthase (eNOS) through a 5-electron oxidation of the guanidine-nitrogen terminal of L-arginine [25]. Generally, NO biovailability indicates a functional and healthy vascular bed. Endothelial-derived NO regulates vasomotor tone (induces vasodilatation activating guanylyl cyclise on subjacent vascular SMCs [26]), blood fluidity and vascular cell growth. As described by Osto et al. [24]: "the activity of endothelial NO depends on the balance between synthesis of NO and its breakdown by superoxide anion (O2-). Under physiological conditions, the production of this molecule is not affected by O2-. Hence, the endothelium-derived NO may exert its wellknown vascular protective effects. However, excessive generation of O2rapidly inactivates NO, leading to the formation of high concentrations of peroxynitrite (ONOO-), a very powerful oxidant. Peroxynitrite easily penetrates across phospholipid membranes and produces substrate nitration, thereby inactivating regulatory receptors and enzymes such as free radical scavengers. Increased production of reactive oxygen species (ROS) is regarded as major determinant of reduced levels of NO. The loss of NO due to enhanced oxidative stress in the vessel wall might be considered the central mediator of all different aspects related to endothelial dysfunction, critically contributing to plaque destabilization in traditional atherosclerosis. The loss of endothelium-derived NO permits increased activity of the pro-inflammatory transcription factor nuclear factor kappa $B(N F-k B)$, resulting in expression of leukocyte adhesion molecules and production of chemokines and cytokines. These actions promote monocytes and vascular SMCs migration into the intima and formation of macrophage foam cells, characterizing the initial morphological changes of atherosclerosis. The activity of the endothelium, thus, extends far beyond the control of vascular tone and reactivity, and the release of vasodilating mediators is only one aspect of its homeostatic and protective roles".

An impaired NO bioavailability, leading to endothelial dysfunction, is a key pathological condition which is associated with most, if not all, cardiovascular diseases and risk factors [27].

The description of all the methods available for clinical endothelial function assessment is away from the scope of this paper: Flammer et. al. well described [27] all these aspects, showing that it is possible to consider the endothelial function as a "barometer" of cardiovascular health useful to direct patient management and evaluation of therapeutic strategies.

Among other vascular beds, the endothelial function can be assessed also at the level of the coronary circulation by mean of the CFR [28]. From what we described so far is easy to understand that reduced CFR can result from the combination of different alterations such as impaired vasodilation, enhanced vasoconstrictor responsiveness, and/ or structural remodeling of the coronary microvasculature. Thus, the functional status of the coronary microcirculation can be assessed by testing endothelium-dependent (using acetylcholine (Ach), bradykinin or substance-P administration) and endothelium-independent (through adenosine, dipyridamole, or papaverine vasodilatating trigger) vascular responses [12]. It is important to consider that rheological factors (such as heightened plasma viscosity and increased red blood cell aggregation) modify blood fluidity. A reduced fluidity may limit the microcirculatory flow due to the viscus resistance [29].

The CFR, defined as the maximal hyperemic flow divided by resting flow, represents the ability of the coronary flow to increase above its basal value when the coronary vascular bed is maximally dilated and is commonly measured by echocardiography and by other techniques (coronary angiograms and fractional flow reserve, positron emission tomography, and magnetic resonance imaging), each one with distinct advantages and limitations [30]. CFRis a global parameter of coronary flow, which is early altered in the presence of a coronary microvascular dysfunction/disease or epicardial coronary artery stenosis. It is possible to study coronary flow in all main coronaries by transthoracic-Doppler echocardiography; however, normally the left anterior descending artery is the coronary of choice. CFR is defined as the ratio of maximal hyperemic to basal diastolic coronary velocity and maximal hyperemic flow is obtained during adenosine infusion. Buus et al. demonstrated in healthy subjects that adenosine-induced myocardial hyperemia is partly dependent on an intact endogenous NO production suggesting that adenosine-mediated vasodilation is partly endothelium dependent [31]. Thus, as we and others confirmed $[7,32,33]$, a decrease in myocardial perfusion reserve may be caused by endothelial dysfunction. We want to stress that the distinction between "endothelium dependent" and "endothelium independent" regulation of coronary function is probably too simplistic and mechanistic. The categorization is based on histological studies and patterns [31], the results of which were then transferred in vivo, not taking into account those paracrine, molecular or even electromagnetic influences weaving intercellular dialogue [34].

CFR represents simple but at the same time very important tool to investigate the physiology and pathophysiology of heart and systemic diseases [27]. It's a marker for cardiovascular risk estimation, and it is also helpful in evaluating therapeutic interventions and prognosis-risk stratification in cardiomyopathies [35], coronary artery disease, and heart transplantation $[35,36]$. Coronary microvascular dysfunction, defined as reduced coronary flow reserve and/or coronary endothelial dysfunction, is associated with a $2.5 \%$ annual major adverse event rate that includes death, nonfatal myocardial infarction, nonfatal stroke, 
and congestive heart failure [37]. Early identification of microvascular coronary disease by echo-derived CFR or other coronary reactivity tests may be beneficial in prognosis evaluation and patient stratification for optimal medical therapy [38]. This is of paramount importance because many diseases, that is, endocrine, metabolic, and immune conditions, affect vascular and in particular coronary function. Finally, endothelial dysfunction has been detected in the coronary epicardial and resistance vasculature as well as in peripheral arteries, so that endothelial dysfunction can be regarded as a systemic condition [39]. On the other hand, the endothelial cells are evenly distributed in all organs and throughout the body even if they receive specific influences related to the district of belonging and its metabolic state.

\section{Psycho-neuro-endocrine-immune system (PNEI), the stress response and epigenetics}

\section{PNEI}

Besedovsky and Sorkin in 1977 first proposed the theory of psychoneuro-endocrine-immune network (PNEI) as an integrated system having the purpose of regulating homeostasis and maintaining the health of the human organism (Figure 2) [40]. The balance of the system affects different pathophysiological conditions such as inflammation [41-43], aging [44], rheumatic disorders [45], cancer [46] and, as we will see, cardiovascular diseases. PNEI system regulates homeostasis of the body producing and secreting an extraordinary variety of

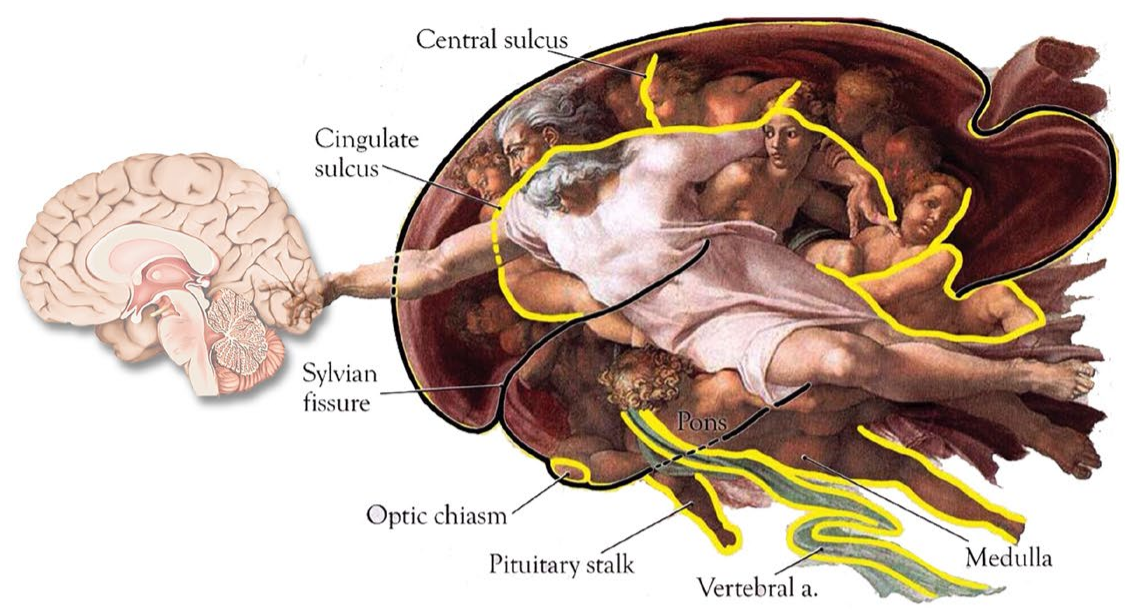

Neurotransmitters
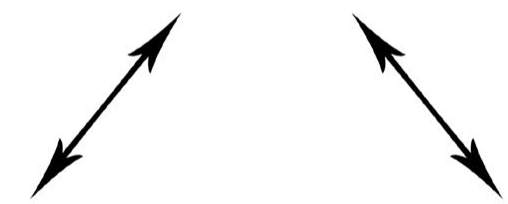

Hormones

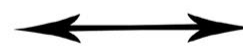

Cytokines

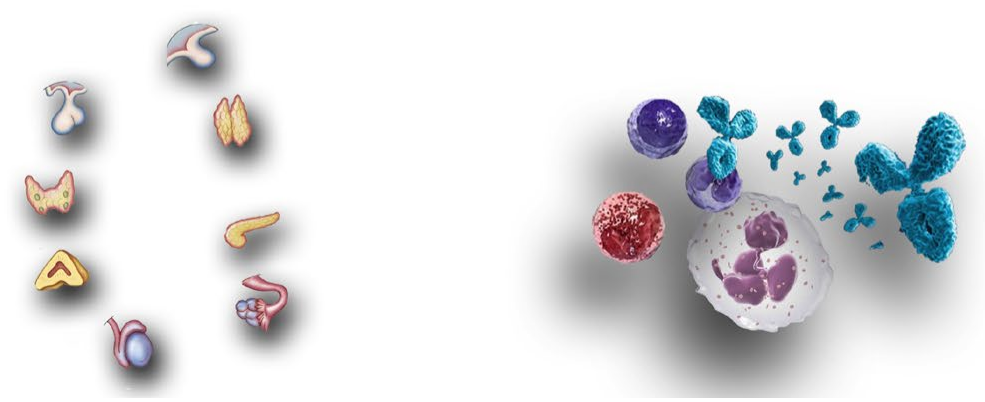

Figure 2. The concept of Psychoneuroendocrineimmunology. Psyche and biological systems are linked. Nowadays, a lot of studies [52,53] document this bi-directional connection and show how psychological states of mind modify the activity and the balance of biologic systems (such as nervous, endocrine, immune and metabolic systems) and how their functioning could influence the mental attitude. For example, depression causes sterile inflammation and a primitive inflammatory event may trigger depressive processes. Furthermore, immunosuppression could be induced by individual behavior and psychological processes (please consult the references cited in the text)."Emotions $<=>$ thoughts $<=>$ actions. As Michelangelo foretold in " Creation of Adam", all gods and demons that ever existed are within us as a possibilities, desires, and ways to escape. Within the dark red vault of our skull we see human and god-like forms reaching out, as thoughts escape into actions - with legs extending into our brainstem and a fist is pushing from our hypothalamus into the pituitary stalk. Above the pituitary we have thoughts, ideas, impulses, and neurotransmitters. Below we have hormones. Between is the realm of neuroendocrinology - the neurosecretory cells which turn emotions into the releasing factors for the pituitary hormones and the immune system that in turn will give their feedback on the brain". Modified from [447]. 
cellular regulatory mediators known as peptides, neurotransmitters, neuropeptides, hormones, cytokines or growth factors [47]. These are the actors that mediate the connection between the psyche and biological systems. These factors influence each other, mediating cellular gene expression in response to environmental factors and a disruption in the network will affect the entire network itself [46-49]. The psyche and biological systems are linked and there are now many studies that document this bidirectional connection [50-52]. The studies show how psychological states of mind modify the activity and the balance of biologic systems (such as the nervous [53], endocrine [54], immune [55] and metabolic systems [56,57]) and how the way they function could influence mental attitude $[52,58,59]$.

In Table 1 are reported the evidences and some mediators and mechanisms by which: 1) nerves talk to immune cells, 2) the immune system plays with the nervous system, 3) hormones and immune cells dialogue and 4) the brain produceshormones that in turn act on the brain. These connections are very complex and still under study by dedicated disciplines and scientific journal (such as neuroimmunoendocrinology [45], neuroimmunology [60], psychoneuroimmunology [61] or neuroendocrinology [62]). There is also an online database that tracks PNEI interactions with related genetic pattern expressions [46,47].

\section{The stress response}

Hans Selye's [56] experiments with rats led to the recognition of the "general adaptation syndrome" and described as the triad of enlarged adrenal glands, lymph node and thymic atrophy, and gastric erosions/ ulcers [63].

All activities and functions in the life of any organism, and of course of human beings, try to maintain a complex and dynamic psychometabolic balance called "homeostasis", which is constantly challenged by internal or external adverse forces termed "stressors" (hot, cold, toxins, infections, wounds, fatigue, psychosocial factors etc.) [64]. As we recently described [65], "stress occurs when homeostasis is threatened or perceived to be so [66]; homeostasis is re-established by various physiological and behavioral adaptive responses that constitute the so called "stress response" [67]. Thus stress could be defined, according to the original Selye's definition, as the general and non-specific response to any request from the environment. Under favorable conditions, individuals can develop vegetative and pleasurable responses that enhance their emotional and intellectual growth and help the survival of their species, such as food intake and sex [68]. In contrast, activation of the stress response during threatening situations beyond the control of the individual can be associated with dysphoria and eventually emotional or somatic disease [69]. Tsigos and Chrousos reviewed the mechanisms underlying the stress response [69]. Briefly, "the main components of the stress system are the corticotropin-releasing hormone (CRH) and locus ceruleus-norepinephrine (LC/NE)-autonomic systems and their peripheral effectors, the pituitary-adrenal axis, and the limbs of the autonomic system. An active stress system leads to behavioral and peripheral changes that improve the ability of the organism to adjust homeostasis and increase its chances for survival. The CRH and LC/NE systems stimulate arousal and attention, as well as the mesocorticolimbic dopaminergic system, which is involved in anticipatory and reward phenomena, and the hypothalamic beta-endorphin system, which suppresses pain sensation and, hence, increases analgesia. CRH inhibits appetite and activates thermogenesis via the catecholaminergic system. Moreover, reciprocal interactions exist between the amygdala and the hippocampus and the stress system, which stimulates these elements and is regulated by them. During stress $\mathrm{CRH}$ inhibits GnRH and through somatostatin, GH, TRH and TSH secretion, which in turn, suppress the reproductive, growth and thyroid functions. Interestingly, all these functions receive and depend on positive catecholaminergic input. The hormones at the end of the hypothalamic-pituitary-adrenal (HPA) axis, glucocorticoids have multiple roles. They simultaneously inhibit the CRH, LC/NE and b-endorphin systems and stimulate the mesocorticolimbic dopaminergic system and the CRH peptidergic central nucleus of the amygdala. In addition, they directly inhibit pituitary gonadotropin, GH and TSH secretion, render the target tissues of sex steroids and growth factors resistant to these substances and suppress the 50 deiodinase, which converts the relatively inactive tetraiodothyronine (T4) to triiodothyronine (T3), contributing further to the suppression of reproductive, growth and thyroid functions. They also have direct as well as insulin-mediated effects on adipose tissue, ultimately promoting visceral adiposity, insulin resistance, dyslipidemia and hypertension (metabolic syndrome $X$ ) and direct effects on the bone, causing "low turnover" osteoporosis. Central CRH, via glucocorticoids and catecholamines, inhibits the inflammatory reaction, while directly secreted by peripheral nerves CRH stimulates local inflammation [70] (immune CRH)"[69].

The stress reaction is therefore an aspecific biological response to any form of danger, which can come from both outside with a biological (virus, bacteria, toxins) or physical (heat, cold, radiation) nature, or following psychological processes as anger or depression (perceived stress) [71]. In this last case, the platelets seem to play a fundamental role $[72,73]$. In fact, it was demonstrated their dysfunction linked to processes of mental depression or anger, resulting in hyperaggregability, increased oxidative stress and thrombotic risk [74]. Furthermore, platelets contain serotonin which has an important vasospastic action in the cardiovascular system [75] as well as being implicated in the pathogenesis of carcinoid syndrome [76]. The neurotransmitter serotonin is an evolutionary ancient molecule that as remarkable modulatory effects in almost all central nervous system integrative functions such as mood, anxiety, stress, aggression, feeding, cognition and sexual behavior [77]. The platelet secretion of serotonin seems to be essential in mediating the interaction between immune $[78,79]$ and neurological system [80]. Moreover, Cocchi et al. [81] revealed that the viscosity of the platelet membrane is a general influencing factor for serotonin receptor uptake and it is involved in many pathologies that recognize serotonin changes; that is scleroderma, inflammatory bowel disease, neuroinflammation, multiple sclerosis and osteoporosis. Platelet membrane viscosity modifies in case of depression [82], and interestingly represent a novel risk factor for ischemic heart disease [83]. A condition of physical or psychological stress leads to increased oxidative stress [84,85], a known risk factor for endothelial health [86]. In this context, an important protective mechanism is the metabolism of bilirubin and its derivatives [87-89]. In fact they produce an antioxidant effect [89] and are able to inhibit platelet aggregation $[91,92]$, explaining the greater level of cardiovascular security of hyperbilirubinemic patients with Gilbert's syndrome [93].

As demonstrated by Charmandari et al., appropriate responsiveness of the stress system to stressors is a crucial prerequisite for a sense of wellbeing, adequate performance of tasks, and positive social interactions. By contrast, inappropriate responsiveness of the stress system may impair growth and development and may account for a number of endocrine, metabolic, autoimmune, and psychiatric disorders [94,95]. The development and severity of these conditions primarily depend 
Dal Lin (2015) Coronary microvascular and endothelial function regulation: Crossroads of psychoneuroendocrine immunitary signals and quantum physics [Part A]

Table 1. Looking over the keyhole of individual scientific disciplines. Neuropeptides, cytokines and hormones and their reciprocal effects in the perspective of the PNEI network.

\begin{tabular}{|c|c|c|c|}
\hline Immune mediators & Endocrinological effects & Neurologic and psychiatric effects & References \\
\hline Interleukin-1 (IL-1) & $\begin{array}{ll}\text { - } & \begin{array}{l}\uparrow \text { adrenocorticotropic hormone (ACTH) } \\
\text { levels }\end{array} \\
\text { - } & \begin{array}{l}\text { glucocorticoids levels (effect abrogated } \\
\text { by the administration of corticotropin- }\end{array} \\
\text { releasing hormone (CRH) antagonists); } & \text { activates growth system } \\
\text { - } & \uparrow \text { prolactin (PRL) secretion } \\
\text { - } & \text { Inhibits gonads function and thyroid’s } \\
\text { function } \\
\text { - } & \uparrow \beta \text { endorphin levels }\end{array}$ & 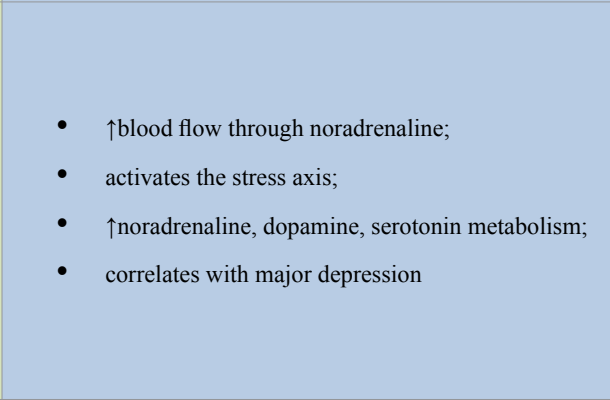 & {$[379,397,401-407]$} \\
\hline Interleukin-1 $\beta$ (IL-1 $\beta)$ & & important role in memory and learning & [408] \\
\hline Interleukin-2 (IL-2) & $\begin{array}{ll}\text { - } & \uparrow \text { ACTH levels; } \\
\text { - } & \uparrow \text { glucocorticoids levels } \\
\text { - } & \text { IL-2 receptor gamma-chain messenger } \\
& \text { RNA (mRNA) is regulated by } \\
\text { gonadotrophin-releasing hormone } \\
\text { (GnRH) in vitro }\end{array}$ & $\begin{array}{l}\text { analgesic effects through interaction of the analgesic domain } \\
\text { of IL2 with the opioid receptor }\end{array}$ & {$[401-403,104,389,409,410]$} \\
\hline Interferon beta (IFN- $\beta$ ) & 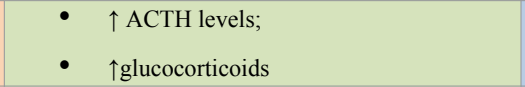 & & [401-404] \\
\hline Interferon gamma (IFN-y) & $\begin{array}{ll}\text { - } & \uparrow \text { ACTH levels; } \\
\text { - } & \uparrow \text { glucocorticoids; } \\
\text { - } & \uparrow \text { melatonin release by the pineal gland; } \\
\text { - } & \begin{array}{l}\text { upregulates glucocorticoid receptor } \\
\text { expression by macrophages }\end{array}\end{array}$ & acts on the glutamate receptor & [401-404,411-413] \\
\hline Leukemia inhibitory factor (LIF) & $\begin{array}{ll}- & \uparrow \text { ACTH levels; } \\
\text { - } & \uparrow \text { glucocorticoids }\end{array}$ & & \\
\hline Tumor necrosis factor-alpha (TNF- $\alpha$ ) & $\begin{array}{l}-\uparrow \text { ACTH levels; } \\
\text { - } \quad \uparrow \text { glucocorticoids }\end{array}$ & $\begin{array}{l}\text { - } \quad \uparrow \text { levels of tryptophan in brain; } \\
\text { - } \quad \uparrow \text { noradrenaline metabolism } \\
\text { - } \quad \text { correlates with major depression }\end{array}$ & {$[401-404,414,397]$} \\
\hline Interleukin-6 (IL-6) & $\begin{array}{ll}\text { - } & \uparrow \text { ACTH levels; } \\
\text { - } & \uparrow \beta \text { endorphin levels; } \\
\text { - } & \text { blocks thyroid stimulating hormone } \\
& \text { (TSH) production; } \\
\text { - } & \text { hinders thyroxine (T4) to triiodothyronine } \\
& \text { (T3) conversion; } \\
\text { - } & \uparrow \mathrm{CRH} \text { levels; } \\
\text { - } & \uparrow \text { arginine vasopressin (AVP) levels }\end{array}$ & $\begin{array}{l}\text { - } \quad \text { levels of serotonin and tryptophan; } \\
\text { - correlates with major depression }\end{array}$ & $\begin{array}{c}{[397,399,401-} \\
403,407,414-416]\end{array}$ \\
\hline Interleukin-10 (IL-10) & $\begin{array}{ll}\text { - } & \uparrow \text { corticotrophin-releasing factor (CRF) } \\
& \text { levels } \\
\text { - } & \uparrow \mathrm{ACTH} \text { levels }\end{array}$ & & [417] \\
\hline $\begin{array}{l}\text { Granulocyte Macrophage colony- } \\
\text { stimulating factor (GM-CSF) }\end{array}$ & $\begin{array}{l}\text { - } \quad \uparrow \text { melatonin release by the pineal gland; } \\
\text { - } \quad \uparrow \text { ACTH levels } \\
\text { - } \quad \uparrow \text { glucocorticoids }\end{array}$ & & {$[411,412,418]$} \\
\hline Granulocyte colony-stimulating factor (G-CSF) & stimulates release of melatonin by the pineal gland & & {$[411,412]$} \\
\hline Histamine & & $\begin{array}{ll}\text { - } & \uparrow \text { release of substance } \mathrm{P} ; \\
\text { - } & \uparrow \text { release of calcitonin gene-related peptide } \\
\text { - } & \begin{array}{l}\text { Inhibits IL-12, TNF and IFN- } \gamma \text { and enhances IL-10 } \\
\text { production }\end{array}\end{array}$ & {$[419,420]$} \\
\hline Macrophage inhibitory factor (MIF) & $\begin{array}{l}\text { is pro-inflammatory by counteracting the } \\
\text { antiinflammatory and immunosuppressive } \\
\text { effects of glucocorticoid inhibition } \\
\text { of T-cell proliferation and cytokine } \\
\text { production; } \\
\text { anterior pituitary cells secrete large } \\
\text { quantitaties of MIF when stimulated with } \\
\text { (lipopolysaccharide) LPS in vitro }\end{array}$ & , & {$[420-423]$} \\
\hline Prostaglandin E2 (PGE2) & & Inhibits IL-2 production & [420] \\
\hline
\end{tabular}




\begin{tabular}{|c|c|c|c|c|}
\hline Nervous mediators & Endocrinological effects & Psychiatric effects & Immunological effects & References \\
\hline Endorphins and enkephalins & $\begin{array}{l}\text { In acute stress } \beta \text { endorphins } \\
\text { inhibit GnRH, follicle-stimulating } \\
\text { hormone (FSH), luteinizing } \\
\text { hormone (LH) release }\end{array}$ & analgesic role & $\begin{array}{l}\text { modulate the } \mathrm{Th} 1 / \mathrm{Th} 2 \text { balance of } \\
\text { the immune system, inhibiting the } \\
\text { Th1 axis; } \\
\text { Inhibit immunoglobulin (Ig) } \\
\text { production; } \\
\text { - Enhances IFN- } \gamma \text { production and } \\
\text { natural killer (NK) cell mediated } \\
\text { cytotoxicity; } \\
\text { - } \\
\text { Inhibits T-cell proliferation; } \\
\text { - } \quad \begin{array}{l}\text { enhances antigen-specific } \\
\text { proliferation }\end{array}\end{array}$ & {$[399,420,424]$} \\
\hline $\begin{array}{l}\text { substance } \mathrm{P} \text { and calcitonin gene-related } \\
\text { peptide }\end{array}$ & & & $\begin{array}{l}\text { Control vascularity of lymphoid } \\
\text { tissue; } \\
\text { induces the release of histamine } \\
\text { from mast cells } \\
\text { - } \quad \begin{array}{l}\text { Increases T-cell adhesion and } \\
\text { stimulates IL-2, IL-4 and IFN- } \gamma \\
\text { production; }\end{array} \\
\text { Enhances T-cell proliferation } \\
\text { and IL-1, IL-6, TNF and IFN- } \gamma \\
\text { production and macrophage action }\end{array}$ & {$[419,420]$} \\
\hline norepinephrine & & & $\begin{array}{l}\text { - Control vascularity of lymphoid } \\
\text { tissue; } \\
\text { Determines a change in the level of } \\
\text { gene expression for cytokines and } \\
\text { antibodies }\end{array}$ & [379] \\
\hline $\begin{array}{l}\text { Acetylcholine (Ach) (Vagus nerve } \\
\text { stimulation) }\end{array}$ & & & $\begin{array}{l}\text { Inhibits proinflammatory cytokine } \\
\text { production by signaling through the } \\
\alpha-7 \text {-nicotinic acetylcholine receptor } \\
\text { subunit; } \\
\text { Stimulates T and NK cells and } \\
\text { increases IFN- } \gamma \text { production }\end{array}$ & {$[420,425]$} \\
\hline Catecholamines/ adrenalin & & $\begin{array}{l}\text { - high levels during pregnancy } \\
\text { mark epigenetically the } \\
\text { offspring's brain and function }\end{array}$ & $\begin{array}{l}\text { - Inhibit Th1 immune responses and } \\
\text { set a Th2 profile during chronic } \\
\text { stress; } \\
\text { - } \quad \text { in acute stress enhance the } \\
\text { production of antibodies and the } \\
\text { proliferation of natural killer cells, } \\
\text { B cells and T cells; activation of the } \\
\text { pro-inflammatory gene NF-kappa B } \\
\text { in monocytes; } \\
\text { - Inhibits IL-1 and IL-2 production; } \\
\text { - } \quad \text { Enhance Ig production. } \\
\text { - Decrease the number of T and NK } \\
\text { cells in the peripheral circulation } \\
\text { inhibit NK cells }\end{array}$ & {$[400,426,427]$} \\
\hline Nerve Growth Factor (NGF) & & & $\begin{array}{l}\text { Low levels of NGF turn off mast- } \\
\text { cell activity; } \\
\text { Enhances B-cell proliferation, } \\
\text { IL-6 production, IL-2 receptor } \\
\text { expression and Ig-G4 synthesis }\end{array}$ & {$[420,428]$} \\
\hline Angiotensin 2 & & & Enhances IFN- $\gamma$ production & [420] \\
\hline Cyclic adenosine monophosphate (cAMP) & & & $\begin{array}{l}\text { - } \\
\text { - } \\
\text { Inhibits IL-2 production }\end{array}$ & [420] \\
\hline Neuropeptide Y & & & $\begin{array}{l}\text { - Increases T-cell adhesion and } \\
\text { stimulates IL-2, IL-4 and IFN- } \gamma\end{array}$ & [420] \\
\hline Serotonin & & & $\begin{array}{l}\text { Inhibits T-cell proliferation and } \\
\text { IFN- } \gamma \text { induced human leukocyte } \\
\text { antigen (HLA) class II expression } \\
\text { - } \\
\text { Enhances NK cytotoxicity }\end{array}$ & [420] \\
\hline
\end{tabular}




\begin{tabular}{|c|c|c|c|}
\hline Hormones & Neurological and psychiatric effects & Immunological effects & References \\
\hline Cortisol and glucocorticoids & $\begin{array}{l}\text { - Glucorticoid excess damages } \\
\text { brain function impairing } \\
\text { memory and cognitive } \\
\text { performance } \\
\text { - } \text { deficiency in stress axis activity } \\
\text { is linked with chronic fatigue } \\
\text { syndrome and seasonal affective } \\
\text { disorder }\end{array}$ & $\begin{array}{l}\text { - inhibit Th1 immune responses and set a Th2 } \\
\text { profile during chronic stress; } \\
\text { - } \quad \text { in acute stress enhance the production of } \\
\text { antibodies and the proliferation of natural killer } \\
\text { cells, B cells and T cells } \\
\text { - } \quad \text { role in the regulation of antigen-specific T-cell } \\
\text { development; } \\
\text { - Inhibits IFN- } \gamma \text {, IL-2, IL-6 and TNF- } \alpha \text {; } \\
\text { - Enhances IL-4 and transforming growth factor } \\
\text { beta (TGF- } \beta \text { ) production; } \\
\text { - Enhances immune cell expression of IL-1, IL-2, } \\
\text { IL-6 and IFN- } \gamma \text { receptors; }\end{array}$ & {$[399,405,420,430-432]$} \\
\hline dehydroepiandrosterone sulfate(DHEAS) & $\begin{array}{l}\text { - plays an anti-depressive and } \\
\text { anxiolytic role in the brain; } \\
\text { - increases memory capacities } \\
\text { that counteract glutamate action }\end{array}$ & $\begin{array}{l}\text { - } \\
\text { - Enhances Thlimmune responses; } \\
\text { proliferation; } \\
\text { - Imparts a Th1 bias }\end{array}$ & {$[44,420,433]$} \\
\hline $\begin{array}{l}\text { Alpha-Melanocyte stimulating hormone( } \alpha \text { - } \\
\text { MSH) }\end{array}$ & & $\begin{array}{l}\text { - is an anti-inflammatory signal; } \\
\text { - Suppresses delayed type hypersensitivity(DTH) } \\
\text { and inhibits IL-1 and IL-2 production via } \\
\text { inhibition of nuclear factor-Kb (NF-kB) }\end{array}$ & {$[420,434]$} \\
\hline Prolactin (PRL) & & 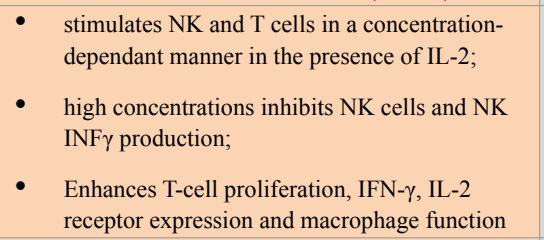 & {$[420,435]$} \\
\hline $\begin{array}{l}\text { Growth hormone (GH) and Insulin-like } \\
\text { Growth Factor-1 (IGF-1) }\end{array}$ & & $\begin{array}{l}\text { - Stimulate neutrophils and macrophages; } \\
\text { - Activates macrophages and enhances } \mathrm{H} 2 \mathrm{O} 2 \\
\text { production; } \\
\text { - Enhance peripheral blood mononuclear cell } \\
\text { (PBMC) proliferation }\end{array}$ & {$[405,420]$} \\
\hline Melatonin & & $\begin{array}{l}\text { reduces tissue destruction during inflammatory } \\
\text { reactions hunting toxic free radicals; prevents } \\
\text { NF-kappa B translocation into the nucleus } \\
\text { and its binding to DNA, thereby reducing the } \\
\text { up-regulation of a variety of pro-inflammatory } \\
\text { cytokines; inhibits production of adhesion } \\
\text { molecules; enhances IFN- y production; } \\
\text { - Enhances IL-1, Il-2, IL-6 } \\
\text { - Imparts a Th1bias }\end{array}$ & {$[420,436-439]$} \\
\hline Corticotropin-releasing hormone (CRH) & $\begin{array}{l}\text { - Chronic high levels lead to: } \\
\text { depression, anxiety, obsessive- } \\
\text { compulsive disorders, such as } \\
\text { anorexia and panic; } \\
\text { - } \\
\text { high levels during pregnancy } \\
\text { mark epigenetically the } \\
\text { offspring's brain and function }\end{array}$ & $\begin{array}{l}\text { - } \\
\text { - Ictivates macrophages; } \\
\text { Inhibits IL-1 and IL-6 production }\end{array}$ & {$[187,420,426,427]$} \\
\hline oxytocin and vasopressin & Correlate with affectivity and sociality & $\begin{array}{ll}\text { - } & \text { Enhances IFN- } \gamma \text { production; } \\
\text { - } & \text { Enhances IFN- } \gamma \text { production }\end{array}$ & {$[121,420]$} \\
\hline Vitamin D & & $\begin{array}{l}\text { - decreases the production of Th1 cytokines } \\
\text { (TNF } \alpha \text { and INF } \gamma \text { ); } \\
\text { - Inhibits IL-2 and IFN- } \gamma \text {; } \\
\text { - Enhances IL-4 production }\end{array}$ & {$[399,420,440]$} \\
\hline Adrenocorticotropic hormone (ACTH) & & $\begin{array}{l}\text { - Inhibits IFN- } \gamma \text { production and Ig production and } \\
\text { blocks macrophage activation by IFN- } \gamma \\
\text { - } \quad \text { TIL-18 mRNA in cells of zona reticularis and } \\
\text { fascicolata }\end{array}$ & {$[420,441]$} \\
\hline
\end{tabular}




Gonadotropin-releasing hormone(Gn-RH)
Inhibin
Luteinizing hormone(LH)
Oestrogen
Progesterone
Somatostatin
Testosterone
Thyroid stimulating hormone (TSH)
Thyroxine
Vasoactive Intestinal Polypeptide(VIP)
on the genetic vulnerability of the individual, the exposure to adverse
environmental factors, and the timing of the stressful events, given
that prenatal life, infancy, childhood, and adolescence are critical
periods characterized by increased vulnerability to stressors [94,96].
A hyper- or hypoactive stress system associated with abnormalities of
the systemic anti-inflammatory feedback and/or hyperactivity of the
local pro-inflammatory factors play a relevant role in the pathogenesis
of chronic inflammation and immune-related diseases, such as
atherosclerosis, hypertension, ischaemic heart diseases (also through
coronary mast cells stimulation [97]) or heart failure [65,95].
Genetics and epigenetics: from the “central dogma of
DNA" to epigenetic genome regulation
and

The old linear correlation between DNA sequences and single proteins [98] has been overwhelmed by the evidence of alternative splicing mechanisms, prion action and epigenetic regulation of DNA expression [99,100]. Tollefsbol et al. well described the science of Epigenetics: "The term epigenetics is defined as the causal interaction between genes and their products that allow for phenotypic expression. Methylation of a particular DNA region silences DNA expression while the deacetylation process produces opposite consequences. Chromatin could be compacted or rolled out by modifying histone tails through methylation, acetylation, phosphorilation, ubiquitination or proline isomerization. Non-coding RNA plays a regulatory role as well. Epigenetics is not only intricately associated with metabolism but also functions in stem cell behavior, $X$ chromosome inactivation, tissue regeneration, genomic imprinting, the transfer of information through generations, neurological memory processes and even the aging of organisms. Epigenetics has also played a role in evolution and has served as a molecular driver of mutations. Moreover, the changing environment is currently re-shaping the evolution of many organisms through plastic epigenetic processes. Epidemiological factors such as diet, environmental exposure, microbial infections and drugs are also influencing daily life through epigenetics. Diseases that have been associated with epigenetic processes range from schizophrenia to cancer and the list of these diseases is rapidly growing longer. Fortunately, the field of epigenetic therapy is also expanding, which provides hope for a future with many new treatments for the numerous diseases arising from epigenetic defects"[101].

Epigenetically, DNA genes are active every single second of our life, responding to thoughts and reacting dynamically and reciprocally to
Increases interleukin-2 receptor (IL-2R) expression,

$\mathrm{T}$ - and B-cell proliferation and serum Ig

[420]

Inhibits IFN- $\gamma$ production

[420]

Enhances IL-2 stimulated T-cell proliferation

Enhances T-cell proliferation and activity IFN- $\gamma$ gene promoter

- Enhances IL-4 production and CD30

$[420,442]$ expression;

- $\quad$ imparts a Th2 bias

Inhibits T-cell proliferation and IFN- $\gamma$ production

Enhances IL-10 production

Enhances IL-2, GM-CSF and Ig production

Activates T cells

- Inhibits T-cell proliferation and IL-12;

- Enhances IL-5 and cAMP production

environmental activation and deactivation. This process starts during pregnancy.

Stress during pregnancy: Environmental conditions during pregnancy could produce epigenetic changes that persist during life [102]. Even individual's birth month has a significant impact on the diseases they develop during their lifetime [103]. Plasticity in developmental programming has evolved in order to provide the best chances of survival and reproductive success to the organism in changing environments. Maternal stress during pregnancy is related to spontaneous preterm birth, low birth weight, congenital malformations [104] and spontaneous abortion [105] due to increased levels of $\mathrm{CRH}$, inflammation and catecholamines that hinder implantation, stabilization and embryo growth [106]. Maternal behavior [107], with its hyperactive stress system and its neuroendocrine balance, epigenetically marks the offspring's brain and function [108] and thus, from what we have seen so far, conditions offspring behavior and thoughts. Furthermore, stress has an impact on health by modulating the rate of cellular aging. Psychological stress (perceived stress and chronic stress) is significantly associated with higher oxidative stress, lower telomerase activity and shorter telomere length, which are known determinants of cell senescence and longevity. If stress occurs in pregnancy, newborn telomeres are shorter as well [109]. Maternal behavior after labor could also epigenetically determine a biological mechanism in the child [110] which is then potentially reversible in adulthood. Hence, epigenetics in early life leaves marks that can be detected in adulthood [111].

Cellular DNA epigenetic marking is stable but reversible: There is evidence that epigenetic differences arise during the lifetime of monozygotic twins $[112,113]$. Cellular DNA epigenetic marking is stable but reversible. From this point of view the paramount importance of research is clear, not only in pharmacological therapy (which could modify an epigenomic DNA mark) but also, as we will see, in behavioral therapies, nutrition, physical activity and stressreduction techniques, which could play a remarkable role in health and be very cost-effective [114-117].

The brain is the central organ for stress and adaptation to stress because it perceives and determines what is threatening, as well as the behavioral and physiological responses to the stressor. Memorizing is a physiologic stress event involving hippocampal neurons. Acetylation and methylation/demethylation mechanisms play an 
important role during the process. A stable methylating process leads to maintaining the mnemonic track [118]. Chronic social defeat stress significantly decreases subsequent social interactions and provokes other depression-like behaviors by inducing histone $\mathrm{H} 3$ deacetylation, a chromatin mark of transcriptional activation, in the hippocampus and amygdala [119]. Social defeat stress induces methylation of the BDNF gene, bringing on a depressant effect [120] and a CRH increase caused by stress axis activation. An opposite effect in the brain reward circuit happens during internal exposure leading to early gene expression modifications in oxytocin and vasopressin (substances related to affectivity and sociality) neurons [121]. Human beings could change their epigenetic depressive states by learning anti-stress mind techniques such as meditation, yoga or tai chi that have effects on genetic expression $[122,123]$. Thus, chronic stress leads to an epigenetic stable brain marking that alters stress axis function, thoughts and behavior and balance of the neuroendocrine system.

What is worrying is that the same configuration is then transmitted to the offspring.

Transgenerational epigenetic transmission: Crews et al. demonstrated how environmental contamination by endocrinedisrupting chemicals (EDC) can have epigenetic effects (through DNA methylation) on the germ line and promote disease across subsequent generations. In natural populations, both sexes may encounter both affected and unaffected individuals during the breeding season and lowered attractiveness could compromise reproductive success. Crews et al. described mate preference in male and female rats whose progenitors had been treated with the antiandrogenic fungicide vinclozolin. This sex-specific effect demonstrates that females three generations removed from the exposure discriminate and prefer males who do not have a history of exposure, whereas similarly epigenetically imprinted males do not exhibit such a preference. The observations suggest that the consequences of EDCs are not just transgenerational but can be "transpopulational", because in many mammalian species, males are the dispersing sex. This result indicates that epigenetic transgenerational inheritance of EDC action represents an unappreciated force in sexual selection. These observations provide direct experimental evidence for a role of epigenetics as a determinant factor in evolution [124]. The majority of environmental toxicants do not have the capacity to modulate DNA sequence, but can alter the epigenome. If an environmental toxicant (such as an endocrine disruptor) modifies the epigenome of a somatic cell, this may promote disease in the exposed individual, but it will not be transmitted to the next generation. But if the toxicant modifies the epigenome of the germ line permanently, then the resulting disease can become transgenerationally transmitted to subsequent progeny [125].

Furthermore, paternal experience across a lifespan can induce germ cell epigenetic reprogramming and impact the offspring's hypothalamic-pituitary-adrenal (HPA) stress axis regulation through specific non-coding microRNAs. It may therefore offer novel insight into factors influencing neuropsychiatric disease risk [126].

Epigenetic modifications are transmissible, but there is also a mechanism that deletes epigenetic signs and that is more powerful in male than in female gametes [127]. Some studies documented a link between nutrition in grandfathers and the risk of diabetes and cardiovascular mortality in their grandchildren [128]. Moreover, male starving some days before fecundation leads to a decrease in levels of IGF-1 and glucocorticoids in the offspring and if a weekly stress condition happens before fecundation, children and grandchildren show stress axis suppression when in contact with stress stimuli [129].

Another example derives from a study by Rehan et al. Asthma is a major public health hazard worldwide. Its transgenerational inheritance has been inferred from epidemiological studies. Rehan's data, for the first time, demonstrated the transgenerational transmission of the asthma phenotype to third generation offspring following perinatal nicotine exposure [130].

Circulating micro-RNAs (miRNA): epigenetic elements of PNEI communication: In recent years, increasing evidence suggests that genetic and epigenetic factors could be involved in disease onset and comorbidity [131-133]. Following the discovery of circulating microRNAs (miRNAs) in Caenorhabditis Elegans more than a decade ago [134], research has majorly evolved in order to gain insight of how the miRNA gene network can have an impact on health and disease in humans. Studies in animal models demonstrate that miRNA genes are essential for life [135], whereas changes in miRNA expression profiles in humans are found in several diseases, such as cancer as well as neurological and cardiovascular disorders [136-139]. The miRNA gene family comprises a class of highly conserved small $(\sim 19-23 \mathrm{nt})$ non protein-coding RNAs that function in the cell to regulate gene expression at the post-transcriptional level [140,141]. Circulating miRNAs are protected by encapsulation in membrane-bound vesicles such as exosomes, but the majority of circulating miRNAs in human plasma and serum cofractionate with Argonaute2 (Ago2) protein, rather than with vesicles [141]. Changes in miRNA expression occurring in the PNEI network and in particular within the heart [142] impact on cardiovascular characteristics by modulating organ function, accentuating cellular stress, and impinging on heart cell survival [143].

The circulating-miRNAs acting on a myriad of genes and protein targets, build a complex network of interactions that are still largely unknown [141]. There are numerous studies that reveal the simple association between some of these elements and several diseases, but the precise mechanism of their action is still unknown [139]. Many different algorithms exist for the bioinformatic prediction of miRNA targets and all generally predict hundreds of targets for each miRNA [144]. As described by Mendell et al. [145], "these highly complex target networks pose a significant challenge to the mechanistic dissection of miRNA-mediated phenotypes. The prevailing model posits that miRNAs function by fine-tuning the expression of numerous targets. While each target is regulated subtly (typically less than a 2-fold change in individual target protein abundance results from gain or loss of miRNA function), the additive effect of coordinated regulation of a large suite of transcripts is believed to result in strong phenotypic outputs [145]. On the other hand, some miRNA-mediated functions might be driven by the strong regulation of one or a few targets" [134,146].

Figure 3 shows the main mechanisms of action of some circulating miRNAs mediating stress signalling within the cardiovascular system. Table 2 shows how a single circulating miRNA acts, even simultaneously, on different target genes, in different diseases and in the various districts composing the PNEI system. (The data are taken from the "miRandola database", available online [141]). Interestingly, more circulating miRNAs are involved in a specific disease, governing differently a same gene expression. 
Stress signal mediation
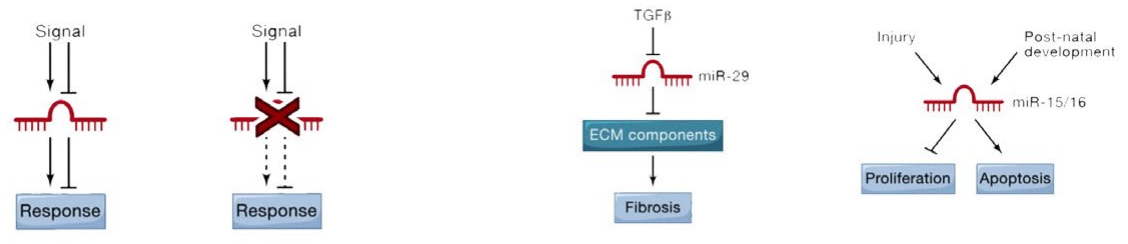

Stress signal modulation
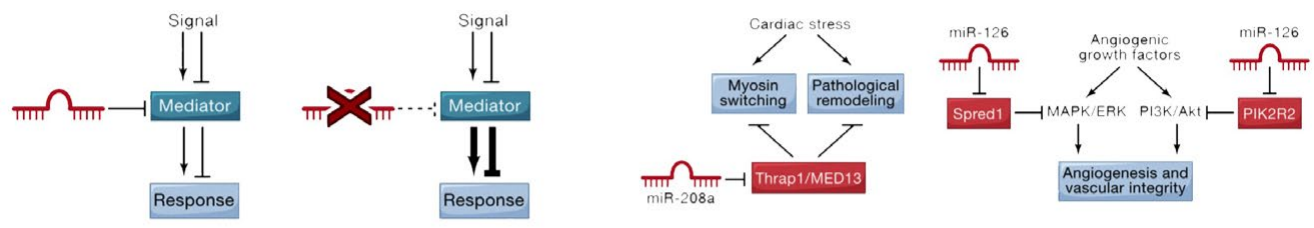

Negative feedback: signal resolution
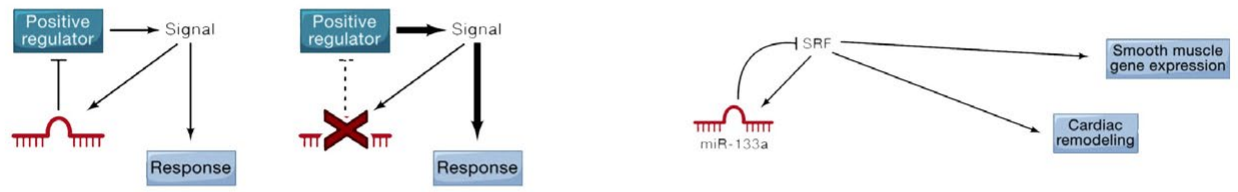

Positive feedback: phenotypic switching
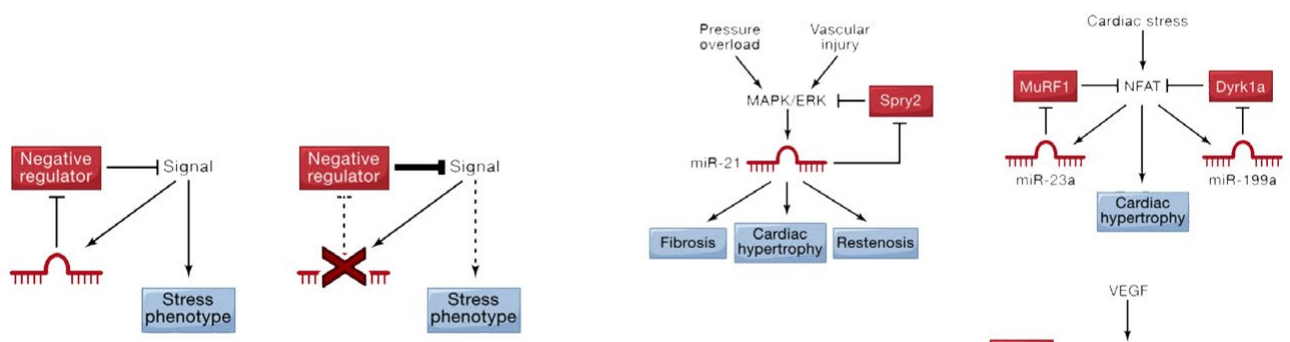

Buffering: signal stability
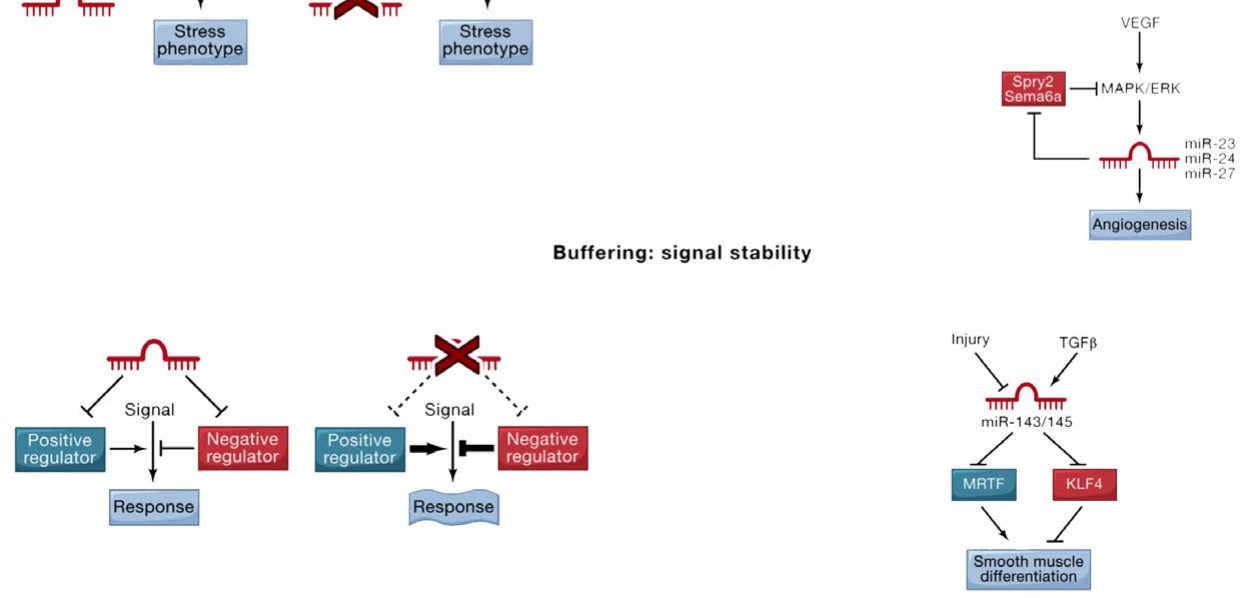

Figure 3. Potential Mechanisms through which miRNAs regulate stress signaling pathways. Observing, on the left is reported the general mechanism, on the right its application in the cardiovascular system. A miRNA can perform a stress signal mediation function in which it acts as a critical intermediate in a signaling pathway. miR-29 and miR-15 family members act as mediators of stress signaling pathways that regulate fibrosis and cardiomyocyte proliferation and survival, respectively. A miRNA may act as a stress signal modulator in which it titrates a signaling intermediate. miR-208a and miR-126 titrate regulators of cardiac remodeling and angiogenesis and thereby function as stress signal modulators. A miRNA may participate in a negative (or positive) feedback loop that serves to dampen or amplify a signal, respectively. miR-133a directly targets its activator SRF and in this manner restrains excessive SRF activity in adult cardiomyocytes, which can lead to heart failure. miR-21, miR-199a, and the miR-23a/27a/24-2 cluster participate in positive feedback loops, which serve to stably activate signaling pathways that lead to pathologic cardiac remodeling and angiogenesis. Lastly, a miRNA may target both activation of the pathway and thereby the stable switching of the cellular state under the stress condition, which can be important for restoring homeostasis but can also contribute to disease (Buffering: Signal Stability). Given the multiplicity of miRNA targets within complex biological pathways, a miRNA may function to buffer pathway activity by simultaneously dampening expression of both positive and negative regulators. In this capacity, the miRNA would prevent stochastic fluctuations in signaling. Under normal conditions or in controlled laboratory environments, this type of buffering may not be critical to maintain normal function. However, in stress states, pathways may need to be transiently activated to a high level thus increasing the requirement for buffering to avoid run-away pathway activation or a failure to achieve the appropriate level of activation. There are documented examples in which gain- and loss-of function of a specific miRNA result in similar phenotypes, which may reflect the perturbation of a buffering function. The miR-143/145 cluster targets both positive and negative regulators of smooth muscle differentiation. Through this buffering activity, these miRNAs maintain the characteristic phenotypic plasticity of this cell type, allowing smooth muscle cells to proliferate in response to injury. 
Dal Lin (2015) Coronary microvascular and endothelial function regulation: Crossroads of psychoneuroendocrine immunitary signals and quantum physics [Part A]

Table 2. Circulating miRNA, diseases in the districts composing the PNEI system and their actions on different target genes (data from miRandola databse [140]).

\begin{tabular}{|c|c|c|c|c|c|c|}
\hline miRNA & $\begin{array}{l}\text { PSYCHIATRIC } \\
\text { DISEASES }\end{array}$ & $\begin{array}{l}\text { NEUROLOGIC } \\
\text { DISEASES }\end{array}$ & $\begin{array}{l}\text { CARDIOVASCULAR } \\
\text { DISEASES }\end{array}$ & $\begin{array}{c}\text { ENDOCRINOLOGICAL } \\
\text { DISEASES }\end{array}$ & $\begin{array}{l}\text { IMMUNOLOGICAL } \\
\text { DISEASES }\end{array}$ & TARGET GENES \\
\hline \multirow[t]{3}{*}{1} & depression & ischemic stroke & atrial fibrillation & diabetes mellitus type 1 & $\begin{array}{l}\text { clozapine induced } \\
\text { agranulocytosis }\end{array}$ & BDNF \\
\hline & autism & Parkinson's disease & Brugada syndrome & Graves' disease & Kawasaki disease & KCNE1 \\
\hline & personality disorders & $\begin{array}{l}\text { morphology and cognitive } \\
\text { function }\end{array}$ & generalized atherosclerosis & $\begin{array}{l}\text { polycystic ovarian } \\
\text { syndrome }\end{array}$ & $\begin{array}{c}\text { acute promyelocytic } \\
\text { leukemia }\end{array}$ & FLT3 \\
\hline \multirow[t]{3}{*}{$10 \mathrm{a}$} & bulimia nervosa & epilepsy & coronary atherosclerosis & Graves' disease & follicular lymphoma & BDNF \\
\hline & schizoaffective disorder & Huntington's disease & $\begin{array}{l}\text { left ventricular } \\
\text { hypertrophy }\end{array}$ & hyperaldosteronism & $\begin{array}{l}\text { drug -induced } \\
\text { agranulocytosis }\end{array}$ & FABP2 \\
\hline & nicotine dependence & glioblastoma multiforme & $\begin{array}{l}\text { cardiac arrhythmias and } \\
\text { sudden death }\end{array}$ & $\begin{array}{l}\text { polycystic ovarian } \\
\text { syndrome }\end{array}$ & $\begin{array}{l}\text { ANCA associated } \\
\text { vasculitis }\end{array}$ & PTEN \\
\hline \multirow[t]{3}{*}{16} & $\begin{array}{l}\text { obsessive compulsive } \\
\text { disorder }\end{array}$ & neurofibromatosis 1 & hypertension & gestational diabetes & leukemia & ATXN1 \\
\hline & Schizophrenia & dementia & coronary artery disease & Graves' disease & sarcoidosis & ADIPOQ \\
\hline & smoking behavior & myotonic dystrophy & $\begin{array}{l}\text { abdominal aortic } \\
\text { aneurysm }\end{array}$ & $\begin{array}{l}\text { polycystic ovarian } \\
\text { syndrome }\end{array}$ & psoriasis & APOA5 \\
\hline \multirow[t]{3}{*}{21} & alcohol abuse & $\begin{array}{l}\text { cerebral vascular } \\
\text { malformations }\end{array}$ & $\begin{array}{l}\text { congenital heart } \\
\text { abnormalities }\end{array}$ & hyperandrogenism & leukemia & BMPR2 \\
\hline & $\begin{array}{l}\text { obsessive compulsive } \\
\text { disorder }\end{array}$ & leukoencephalopathy & $\begin{array}{l}\text { hypertension and } \\
\text { myocardial infarction }\end{array}$ & hypoparathyroidism & lymphoma & PPARA \\
\hline & schizophrenia & epilepsy & pulmonary hypertension & early menopause & agammaglobulinemia & TLR4 \\
\hline \multirow[t]{3}{*}{24} & autism & meningioma & coronary atherosclerosis & Cushing's syndrome & acute leukemia & CDKN2A \\
\hline & anxiety disorder & $\begin{array}{l}\text { ALS/amyotrophic lateral } \\
\text { sclerosis }\end{array}$ & hypertension & hyperparathyroidism & non-Hodgkin's lymphoma & MTHFR \\
\hline & bipolar disorder & Alzheimer's disease & $\begin{array}{c}\text { left ventricular } \\
\text { hypertrophy }\end{array}$ & pituitary carcinoma & Behcet's Disease & APOA5 \\
\hline \multirow[t]{3}{*}{ 29a } & major depression & ischemic stroke & $\begin{array}{c}\text { carotid and coronary } \\
\text { atherosclerosis }\end{array}$ & $\begin{array}{l}\text { autoimmune thyroid } \\
\text { disease }\end{array}$ & leukemia & BACE1 \\
\hline & autism & myasthenia gravis & $\begin{array}{c}\text { abdominal aortic } \\
\text { aneurysm }\end{array}$ & $\begin{array}{l}\text { diabetes mellitus type } 1 \\
\text { and } 2\end{array}$ & graft versus host disease & DNMT3B \\
\hline & drug abuse & meningioma & mitral valve prolapse & male infertility & $\begin{array}{l}\text { severe combined } \\
\text { immunodeficiency }\end{array}$ & PPARGC1A \\
\hline \multirow[t]{3}{*}{$34 \mathbf{a}$} & anxiety disorder & impaired memory & coronary atherosclerosis & $\begin{array}{l}\text { diabetes mellitus type } 1 \\
\text { and } 2\end{array}$ & Hodgkin's disease & VEGFA \\
\hline & autism & tardive dyskinesia & dilated cardiomyopathy & pheochromocytoma & leukemia & BCL2 \\
\hline & sleep disturbances & frontotemporal dementia & ischemic heart disease & thyroid cancer & Behcet's Disease & HTR2C \\
\hline \multirow[t]{3}{*}{$92 \mathrm{a}$} & affective psychoses & neuropathy & myocardial infarction & premature ovarian failure & atopy & EN2 \\
\hline & autism spectrum disorder & anaplastic astrocytoma & Cardiomyopathy & polycystic ovary syndrome & systemic sclerosis & PAFAH1B1 \\
\hline & anorexia nervosa & $\begin{array}{l}\text { ALS/amyotrophic lateral } \\
\text { sclerosis }\end{array}$ & coronary atherosclerosis & $\begin{array}{l}\text { Graves' disease and } \\
\text { Hashimoto's thryoiditis }\end{array}$ & agranulocytosis & GCLM \\
\hline \multirow[t]{3}{*}{122} & anorexia nervosa & epilepsy & hypertension & $\begin{array}{l}\text { diabetes mellitus type } 1 \\
\text { and } 2\end{array}$ & primary biliary cirrhosis & GYS1 \\
\hline & nicotine dependence & migraine with aura & acute coronary syndrome & Graves' disease & pemphigus & NTRK2 \\
\hline & $\begin{array}{l}\text { post traumatic stress } \\
\text { disorder }\end{array}$ & brain aneurysm & atrial fibrillation & hyperandrogenism & $\begin{array}{c}\text { Common Variable Immune } \\
\text { Deficiency }\end{array}$ & IL1RN \\
\hline \multirow[t]{3}{*}{$125 \mathrm{~b}$} & schizophrenia & multiple sclerosis & acute coronary syndrome & $\begin{array}{l}\text { multiple endocrine } \\
\text { neoplasia (MEN) }\end{array}$ & sarcoidosis & ERBB3 \\
\hline & alcoholism & myotonic dystrophy & $\begin{array}{l}\text { congenital heart } \\
\text { abnormalities }\end{array}$ & $\begin{array}{l}\text { polycystic ovarian } \\
\text { syndrome }\end{array}$ & $\begin{array}{l}\text { severe combined } \\
\text { immunodeficiency }\end{array}$ & IL1RN \\
\hline & personality disorders & Parkinson's disease & cardiac arrhythmias & $\begin{array}{l}\text { autoimmune thyroid } \\
\text { disease }\end{array}$ & Hodgkin's disease & CYP1A1 \\
\hline \multirow[t]{3}{*}{126} & Schizophrenia & Alzheimer's disease & hypertension & diabetes mellitus type 2 & Hodgkin's disease & BCL2 \\
\hline & bipolar disorder & multiple sclerosis & myocardial infarction & hyperandrogenism & follicular lymphoma & VCAM1 \\
\hline & depression & Huntington's disease & coronary atherosclerosis & $\begin{array}{l}\text { polycystic ovarian } \\
\text { syndrome }\end{array}$ & LES & IRS1 \\
\hline \multirow[t]{2}{*}{$129-5 p$} & major depression & impaired memory & hypertension & autoimmune diabetes & follicular lymphoma & CAMTA1 \\
\hline & drug abuse & neurofibromatosis 1 & $\begin{array}{l}\text { complications related to } \\
\text { heart transplant }\end{array}$ & $\begin{array}{l}\text { autoimmune thyroid } \\
\text { disease }\end{array}$ & LES & ACSL4 \\
\hline
\end{tabular}




\begin{tabular}{|c|c|c|c|c|c|c|}
\hline & schizophrenia & epilepsy & aortic valve sclerosis & hyperandrogenism & Behcet's Disease & BCL6 \\
\hline \multirow[t]{3}{*}{$133 \mathrm{a}$} & ADHD & Alzheimer's disease & atrial fibrillation & diabetes mellitus type 2 & non-Hodgkin's lymphoma & $\mathrm{KCNH} 2$ \\
\hline & Schizophrenia & multiple sclerosis & long QT syndrome & hypothyroidism & atopy & CASP9 \\
\hline & alcohol abuse & epilepsy & $\begin{array}{l}\text { hypertension myocardial } \\
\text { infarction }\end{array}$ & $\begin{array}{l}\text { polycystic ovarian } \\
\text { syndrome }\end{array}$ & sarcoidosis & DLG5 \\
\hline \multirow[t]{3}{*}{$133 \mathrm{~b}$} & bipolar disorder & $\begin{array}{c}\text { ALS/amyotrophic lateral } \\
\text { sclerosis }\end{array}$ & coronary atherosclerosis & premature ovarian failure & non-Hodgkin's lymphoma & ADCYAP1 \\
\hline & anorexia nervosa & multiple sclerosis & acute coronary syndrome & Graves' disease & $\begin{array}{l}\text { ANCA associated } \\
\text { vasculitis }\end{array}$ & LPL \\
\hline & autism & impaired memory & aortic dissection & Addison's disease & acute myeloid leukemia & DRD4 \\
\hline \multirow[t]{3}{*}{138} & major depression & Parkinson's disease & atrial fibrillation & premature pubarche & multiple myeloma & MINK1 \\
\hline & smoking behavior & ischemic stroke & coronary atherosclerosis & Graves' disease & non-Hodgkin's lymphoma & PHOX2B \\
\hline & schizophrenia & neuropathy & $\begin{array}{l}\text { congenital heart } \\
\text { abnormalities }\end{array}$ & hyperaldosteronism & allergic rhinitis & RXRA \\
\hline \multirow[t]{3}{*}{$139-5 p$} & autism & $\begin{array}{l}\text { Becker and Duchenne } \\
\text { muscular dystrophy }\end{array}$ & coronary atherosclerosis & early menopause & Hodgkin's disease & HMGCR \\
\hline & mental retardation & myotonic dystrophy & long QT syndrome & $\begin{array}{c}\text { primary } \\
\text { hyperparathyroidism }\end{array}$ & leukemia & ATXN1 \\
\hline & personality disorders & polyneuropathy & $\begin{array}{c}\text { congenital heart } \\
\text { abnormalities }\end{array}$ & premature pubarche & $\begin{array}{l}\text { inflammatory bowel } \\
\text { diseases }\end{array}$ & PMP22 \\
\hline \multirow[t]{3}{*}{$142-5 p$} & mental retardation & Parkinson's disease & myocardial infarction & pinealoma & myeloid leukemia & DIO2 \\
\hline & psychosis & Creutzfeldt-Jakob disease & hypertension & $\begin{array}{l}\text { polycystic ovarian } \\
\text { syndrome }\end{array}$ & immunodeficiency & SLC18A2 \\
\hline & anxiety disorder & multiple sclerosis & long QT syndrome & pheochromocytoma & Chron's disease & CALCRL \\
\hline \multirow[t]{3}{*}{143} & anorexia nervosa & Alzheimer's disease & heart failure & Addison's disease & $\begin{array}{l}\text { acute myeloid leukemia } \\
\text { M4 }\end{array}$ & FGF1 \\
\hline & anxiety disorder & meningioma & hypertension & male infertility & follicular lymphoma & PTGS2 \\
\hline & ADHD & cerebro vascular ischemia & aortic stenosis & diabetes mellitus type 1 & sarcoidosis & $\mathrm{CBFB}$ \\
\hline \multirow[t]{3}{*}{144} & mental retardation & spinocerebellar ataxia & myocardial infarction & $\begin{array}{l}\text { diabetes mellitus type } 1 \\
\text { and } 2\end{array}$ & $\begin{array}{l}\text { inflammatory bowel } \\
\text { diseases }\end{array}$ & ABCA1 \\
\hline & alcoholism & cerebro vascular ischemia & $\begin{array}{l}\text { left ventricular } \\
\text { hypertrophy }\end{array}$ & premature ovarian failure & LES & FMR1 \\
\hline & schizophrenia & Alzheimer's disease & heart failure & Hashimoto's thyroiditis & $\begin{array}{l}\text { porpora di Scholein } \\
\text { Henoch }\end{array}$ & GABRA1 \\
\hline \multirow[t]{3}{*}{145} & $\begin{array}{l}\text { antisocial personality } \\
\text { disorder }\end{array}$ & $\begin{array}{l}\text { ALS/amyotrophic lateral } \\
\text { sclerosis }\end{array}$ & coronary artery disease & hyperandrogenism & leukemia & IRS1 \\
\hline & anorexia nervosa & Alzheimer's disease & hypertension & $\begin{array}{l}\text { polycystic ovarian } \\
\text { syndrome }\end{array}$ & Sjogren's syndrome & NEDD4L \\
\hline & bipolar disorder & $\begin{array}{l}\text { agenesis of the corpus } \\
\text { callosum }\end{array}$ & atrial fibrillation & Addison's disease & autoimmune hepatitis & GJA5 \\
\hline \multirow[t]{3}{*}{$146 b-5 p$} & depression & cerebro vascular ischemia & $\begin{array}{l}\text { carotid and coronary } \\
\text { atherosclerosis }\end{array}$ & $\begin{array}{l}\text { polycystic ovarian } \\
\text { syndrome }\end{array}$ & agranulocytosis & CCL5 \\
\hline & ADHD & Hirschsprung's disease & acute coronary syndrome & Addison's disease & Wegener's granulomatosis & RET \\
\hline & aggressive behavior & Alzheimer's disease & cardiac arrhythmias & $\begin{array}{l}\text { diabetes mellitus type } 1 \\
\text { and } 2\end{array}$ & non-Hodgkin's lymphoma & PDE11A \\
\hline \multirow[t]{3}{*}{150} & Alcoholism & epilepsy & aortic stiffness & acromegaly & primary biliary cirrhosis & GABRG2 \\
\hline & $\begin{array}{l}\text { obsessive compulsive } \\
\text { disorder }\end{array}$ & subarachnoid bleeding & heart failure & hyperaldosteronism & granulomatosi di Wegener & CACNA1G \\
\hline & ADHD & Huntington's disease & myocardial infarction & hyperglycemia & non-Hodgkin's lymphoma & IL1A \\
\hline \multirow[t]{3}{*}{155} & schizophrenia & epilepsy & $\begin{array}{l}\text { coronary and generalized } \\
\text { atherosclerosis }\end{array}$ & $\begin{array}{c}\text { autoimmune thyroid } \\
\text { disease }\end{array}$ & $\begin{array}{l}\text { ANCA associated } \\
\text { vasculitis }\end{array}$ & AGTR1 \\
\hline & eating disorders & ischemic stroke & heart failure & $\begin{array}{l}\text { hypoparathyroidism and } \\
\text { hyperparathyroidism }\end{array}$ & chronic myeloid leukemia & CTLA4 \\
\hline & anxiety disorder & leukoencephalopathy & hypertension & $\begin{array}{l}\text { polycystic ovarian } \\
\text { syndrome }\end{array}$ & MGUS and myeloma & KRAS \\
\hline 181b & ADHD & dementia & aortic valve sclerosis & $\begin{array}{l}\text { pancreatic endocrine } \\
\text { tumors }\end{array}$ & graft-versus-host disease & ESR1 \\
\hline
\end{tabular}




\begin{tabular}{|c|c|c|c|c|c|c|}
\hline & drug abuse & essential tremor & heart failure & $\begin{array}{l}\text { diabetes mellitus type } 1 \\
\text { and } 2\end{array}$ & non-Hodgkin's lymphoma & TNF \\
\hline & depression & trigeminal neuralgia & hypertension & hypothyroidism & Sjogren's syndrome & PPARA \\
\hline \multirow[t]{3}{*}{192} & mental retardation & $\begin{array}{l}\text { charcot marie tooth } \\
\text { disease }\end{array}$ & atrial fibrillation & acromegaly & LES & MECP2 \\
\hline & affective psychoses & epilepsy & $\begin{array}{l}\text { complications related to } \\
\text { heart transplant }\end{array}$ & Addison's disease & graft-versus-host disease & OPRM1 \\
\hline & alcol craving & Creutzfeldt-Jakob disease & hypertension & hyperandrogenism & $\begin{array}{l}\text { inflammatory bowel } \\
\text { diseases }\end{array}$ & SSTR2 \\
\hline \multirow[t]{3}{*}{$193 b$} & autism & meningioma & mitral valve prolapse & $\begin{array}{l}\text { diabetes mellitus type } 1 \\
\text { and } 2\end{array}$ & $\begin{array}{l}\text { ANCA associated } \\
\text { vasculitis }\end{array}$ & PTEN \\
\hline & anxiety disorder & frontotemporal dementia & $\begin{array}{l}\text { hypertensive } \\
\text { cardiomyopathy }\end{array}$ & hypothyroidism & $\begin{array}{l}\text { acute promyelocytic } \\
\text { leukemia }\end{array}$ & PLAU \\
\hline & bipolar disorder & narcolepsy & $\begin{array}{c}\text { hypertrophic } \\
\text { cardiomyopathy }\end{array}$ & $\begin{array}{l}\text { polycystic ovarian } \\
\text { syndrome }\end{array}$ & $\begin{array}{l}\text { anti-phospholipid } \\
\text { syndrome }\end{array}$ & TFAP2B \\
\hline \multirow[t]{3}{*}{195} & psychosis & ataxia & acute coronary syndrome & hyperparathyroidism & follicular lymphoma & ADRB2 \\
\hline & anxiety disorder & cerebrovascular diseases & heart failure & hypothyroidism & Hodgkin's disease & SLC6A4 \\
\hline & sindrome premestruale & Huntington's disease & long QT syndrome & pheochromocytoma & psoriasis & ANK2 \\
\hline \multirow[t]{3}{*}{203} & bipolar disorder & ataxia & cardiac arrhythmias & $\begin{array}{l}\text { diabetes mellitus type } 1 \\
\text { and } 2\end{array}$ & $\begin{array}{l}\text { ANCA associated } \\
\text { vasculitis }\end{array}$ & FMR1 \\
\hline & personality disorders & myasthenia gravis & acute coronary syndrome & Graves' disease & LES & EDN1 \\
\hline & mental retardation & Guillain-Barre's sindrome & $\begin{array}{l}\text { isolated idiopathic dilated } \\
\text { cardiomyopathy }\end{array}$ & premature pubarche & non-Hodgkin's lymphoma & CD1D \\
\hline \multirow[t]{3}{*}{$208(a, b)$} & bipolar disorder & Alzheimer's disease & generalized atherosclerosis & Addison's disease & graft-versus-host disease & HTR2C \\
\hline & depression & $\begin{array}{l}\text { ALS/amyotrophic lateral } \\
\text { sclerosis }\end{array}$ & heart failure & diabetes mellitus type 2 & LES & FLT3 \\
\hline & personality disorders & meningioma & acute coronary syndrome & $\begin{array}{l}\text { polycystic ovarian } \\
\text { syndrome }\end{array}$ & multiple myeloma & VDR \\
\hline \multirow[t]{3}{*}{222} & psychosis & Multiple sclerosis & $\begin{array}{l}\text { Abdominal aortic } \\
\text { aneurysm }\end{array}$ & Male infertility & psoriasis & ESR1 \\
\hline & schizophrenia & spinocerebellar ataxia & aortic valve stenosis & hypothyroidism & $\begin{array}{l}\text { ANCA associated } \\
\text { vasculitis }\end{array}$ & CD4 \\
\hline & alcoholism & cerebral hemorrhage & Brugada syndrome & $\begin{array}{l}\text { pancreatic endocrine } \\
\text { tumors }\end{array}$ & ankylosing spondylitis & KIR3DL1 \\
\hline \multirow[t]{3}{*}{223} & mental retardation & ischemic stroke & myocardial infarction & Addison's disease & Behcet's Disease & MECP2 \\
\hline & alcoholism & $\begin{array}{l}\text { ALS/amyotrophic lateral } \\
\text { sclerosis }\end{array}$ & coronary atherosclerosis & Graves' disease & acute leukemia & ITGB1 \\
\hline & bipolar disorder & frontotemporal dementia & $\begin{array}{l}\text { calcific aortic valve } \\
\text { stenosis }\end{array}$ & $\begin{array}{l}\text { diabetes mellitus type } 1 \\
\text { and } 2\end{array}$ & $\begin{array}{l}\text { anti-phospholipid } \\
\text { syndrome }\end{array}$ & CIITA \\
\hline \multirow[t]{3}{*}{ 331-3p } & ADHD & Alzheimer's disease & coronary atherosclerosis & Graves' disease & atopy & TNF \\
\hline & major depression & cerebral hemorrhage & heart failure & early menarche & graft-versus-host disease & LEP \\
\hline & alcoholism & narcolepsy & acute coronary syndrome & $\begin{array}{l}\text { diabetes mellitus type } 1 \\
\text { and } 2\end{array}$ & Behcet's Disease & UCP3 \\
\hline \multirow[t]{3}{*}{340} & bulimia nervosa & $\begin{array}{l}\text { ALS/amyotrophic lateral } \\
\text { sclerosis }\end{array}$ & acute coronary syndrome & Graves' disease & acute myeloid leukemia & ITGB3 \\
\hline & anxiety disorder & cerebral hemorrhage & atrial fibrillation & hyperandrogenism & atopy & MLL \\
\hline & ADHD & dystonia & hypertension & hyperparathyroidism & $\begin{array}{c}\text { inflammatory bowel } \\
\text { diseases }\end{array}$ & CLOCK \\
\hline \multirow[t]{3}{*}{$376 a$} & eating disorders & multiple sclerosis & $\begin{array}{l}\text { abdominal aortic } \\
\text { aneurysm }\end{array}$ & hypothyroidism & acute myeloid leukemia & HTR2C \\
\hline & drug abuse & neural tube defects & myocardial infarction & $\begin{array}{l}\text { polycystic ovarian } \\
\text { syndrome }\end{array}$ & Behcet's Disease & MBL2 \\
\hline & $\begin{array}{l}\text { obsessive compulsive } \\
\text { disorder }\end{array}$ & ischemic stroke & long QT syndrome & pheochromocytoma & sclerosing cholangitis & CFTR \\
\hline \multirow[t]{2}{*}{484} & Alagille's sindrome & headache & hypertension & male infertility & Kawasaki disease & JAG1 \\
\hline & personality disorders & $\begin{array}{c}\text { cerebral amyloid } \\
\text { angiopathy }\end{array}$ & heart failure & hyperandrogenism & $\begin{array}{l}\text { acute mieloblastic } \\
\text { leukemia }\end{array}$ & GPX1 \\
\hline
\end{tabular}




\begin{tabular}{|c|c|c|c|c|c|c|}
\hline & delirium tremens & multiple sclerosis & $\begin{array}{l}\text { congenital heart } \\
\text { abnormalities }\end{array}$ & $\begin{array}{l}\text { polycystic ovarian } \\
\text { syndrome }\end{array}$ & psoriasis & SLC6A3 \\
\hline \multirow[t]{3}{*}{ 499-3p } & alcohol abuse & Alzheimer's disease & acute coronary syndrome & diabetes mellitus type 2 & $\begin{array}{c}\text { inflammatory bowel } \\
\text { diseases }\end{array}$ & ADIPOQ \\
\hline & $\begin{array}{l}\text { antisocial personality } \\
\text { disorders }\end{array}$ & ischemic stroke & $\begin{array}{l}\text { congenital heart } \\
\text { abnormalities }\end{array}$ & endometrial cancer & Hodgkin's disease & MAOA \\
\hline & bipolar disorder & cognitive function & hypertension & premature ovarian failure & non-Hodgkin's lymphoma & SNAP25 \\
\hline \multirow[t]{3}{*}{$499-5 p$} & psychosis & Tourette's sindrome & myocardial infarction & Graves' disease & Hodgkin's disease & HTR2C \\
\hline & Schizophrenia & ischemic stroke & heart failure & pheochromocytoma & Kawasaki disease & BCL2 \\
\hline & depression & $\begin{array}{l}\text { ALS/amyotrophic lateral } \\
\text { sclerosis }\end{array}$ & aortic stenosis & $\begin{array}{l}\text { diabetes mellitus type } 1 \\
\text { and } 2\end{array}$ & leukemia & VHL \\
\hline \multirow[t]{3}{*}{608} & anorexia nervosa & cerebrovascular diseases & coronary atherosclerosis & Addison's disease & sclerosing cholangitis & HLA-DQA1 \\
\hline & $\begin{array}{l}\text { antisocial personality } \\
\text { disorder }\end{array}$ & epilepsy & atrial fibrillation & $\begin{array}{l}\text { congenital adrenal } \\
\text { hyperplasia }\end{array}$ & Chron's disease & HTR1D \\
\hline & autism & glioblastoma multiforme & $\begin{array}{l}\text { hypertensive } \\
\text { cardiomyopathy }\end{array}$ & gestational diabetes & $\begin{array}{l}\text { Henoch-Schönlein } \\
\text { purpura }\end{array}$ & PAX2 \\
\hline \multirow[t]{3}{*}{625} & anxiety disorder & $\begin{array}{l}\text { impaired cognitive } \\
\text { function }\end{array}$ & coronary atherosclerosis & hyperaldosteronism & acute myeloid leukemia & ADIPOQ \\
\hline & eating disorders & primary dystonia & cardiac arrhythmias & Kallmann syndrome & $\begin{array}{l}\text { anti-phospholipid } \\
\text { syndrome }\end{array}$ & EDN1 \\
\hline & $\begin{array}{l}\text { obsessive compulsive } \\
\text { disorder }\end{array}$ & HIV-leukoencephalopathy & $\begin{array}{l}\text { congenital heart } \\
\text { abnormalities }\end{array}$ & Addison's disease & psoriatic arthritis & TBP \\
\hline \multirow[t]{3}{*}{$1207-5 p$} & anxiety disorder & $\begin{array}{l}\text { ALS/amyotrophic lateral } \\
\text { sclerosis }\end{array}$ & $\begin{array}{l}\text { abdominal aortic } \\
\text { aneurysm }\end{array}$ & Addison's disease & $\begin{array}{l}\text { ANCA associated } \\
\text { vasculitis }\end{array}$ & FCGR2B \\
\hline & bipolar disorder & ataxia & acute coronary syndrome & Hashimoto's thyroiditis & $\begin{array}{l}\text { drug -induced } \\
\text { agranulocytosis }\end{array}$ & ELN \\
\hline & hallucinations & $\begin{array}{l}\text { charcot marie tooth } \\
\text { disease }\end{array}$ & atrial fibrillation & hyperaldosteronism & $\begin{array}{l}\text { Henoch-Schönlein } \\
\text { purpura }\end{array}$ & VEGFA \\
\hline
\end{tabular}

\section{The heart as well as being included in the PNEI network is itself a PNEI organ}

The PNEI network that constitutes the human body is responsible for the process of human adaptation to the environment and its status, its mode of activation has important consequences on both the psychological and the biological level, not only of the individual but also of future generations, through epigenetic marking mechanisms.

The heart and the cardiovascular system belong to this network.

\section{The brain-heart symphony}

Neurologic and cardiovascular diseases: two sides of the same coin?: Over the past years, there is increasing evidence about the brain-heart interaction with major potential implications for treatment of neurological and cardiovascular diseases [147,148]. A number of experimental data provide evidence that intensity of the cardiovascular responses to stress is regulated by neuropeptides. Vasopressin, angiotensin II and interleukin-1beta (IL-1 beta) appear to be responsible for exaggeration of the cardiovascular responses to stress whereas oxytocin seems to act in the opposite way [149].

Cerebrovascular accidents and transient ischemic attacks are frequently caused by cardiac arrhythmias (such as atrial fibrillation) and/or congestive heart failure. On the other hand, cerebrovascular dysfunction may lead to electrocardiographic disorders and cardiac rhythm disturbances. Subarachnoid bleeding may lead to dramatic electrocardiographic changes and even ventricular fibrillation, possibly due to QT-interval prolongation [150,151]. Even mental stress alone can induce cardiac electrical instability, arrhythmias [152] and elecrocardiographic T waves' changes at lower heart rates than observed with exercise [153]. Furthermore, psychosocial stress is associated with detectable plasma levels of troponin in healthy subjects, independently of the presence of coronary atherosclerosis [154].

During a cardiac arrest the brain isn't hypoactive and presents an high-frequency coherent activity [155]. Panic disorders and emotional distress such as the Takotsubo syndrome may give rise to fatal arrhythmias, ensuing transient left ventricular dysfunction with troponin release from myocytes and symptoms similar to those of myocardial infarction [156-158]. Amyotrophic lateral sclerosis and several central nervous system disorders can produce a 'pseudoinfarction' pattern on the electrocardiogram, with ST elevation followed by biphasic $\mathrm{T}$ and inverted $\mathrm{T}$ without any detectable myocardial abnormality [159].

Researches in patients with long QT syndrome, Brugada syndrome and catecholaminergic polymorphic ventricular tachycardia revealed that the abnormal ion channel characteristics of these people may not be the only explanation for sudden death and that differences in autonomic patterning are critical [160]. This could be interpreted that the mutation creates the substrate of the arrhythmia, but the autonomic nervous system is a modulating factor that leads to the fatal triggers in situations of heightened adrenergic drive, specifically anger and exercise or unexpected acoustic stimuli during rest or sleep [160]. Moreover, patients with long QT syndrome have abnormal electroencephalograms [161].

Diabetic autonomic neuropathy being a common complication of diabetes mellitus is related to an increased risk of cardiovascular mortality [162]. Spinal cord stimulation imparts cardioprotection under conditions of neuronally dependent cardiac stress [163] and mitigates transient ischemia-induced myocardial infarction [164]. Moreover, an intra- and extra-cardiac neuronal remodeling happens after a myocardial infarction [165]. Coronary artery bypass surgery has major effects on neurocognitive functioning $[166,167]$. Furthermore, 
chronic vascular and congenital heart disease patients present a peculiar neuroncognitive decline [168]. Exercise stimuli may prevent or slow down the cognitive decline in elderly patients with heart failure $[169,170]$. It has been demonstrated the strict connection between cerebral activity and cardiorespiratory synchronization [171] and baroreflex control of heart rate [172]. Parkinson's disease could lead to autonomic failure with cardiac and extracardiac sympathetic denervation and orthostatic hypotension [173]. "Cathecolamine autotoxicity" plays an important role both in Parkinson and in cardiovascular diseases $[9,174,175]$.

It has recently been proposed that heart failure is a risk factor for Alzheimer's disease [176]. Decreased cerebral blood flow and neurohormonal activation due to heart failure may contribute to the dysfunction of the neurovascular unit and cause an energy crisis in neurons. This leads to the impaired clearance of amyloid beta and hyper phosphorylation of tau protein, resulting in the formation of amyloid beta plaques and neurofibrillary tangles [176]. Heart failure seems to relate with dementia being vascular dementia the most common dementia disorder [177]. Lee et al. have identified a common network of genes (and metabolic pathways) that was altered in Alzheimer's disease coinciding with myocardial infarction [131].

Both Parkinson's and Alzheimer's disease are linked to dementia and depression [178-185]. Depression is an important risk of cardiovascular events. It causes and in the meantime is worsened by immune dysregulation [186-190] that in turn is related to atherosclerosis, endothelial dysfunction, coronary artery disease [191] and calcification [192], myocardial infarction[193] and heart failure $[194,195]$. A recent study by Batty et al. confirmed that psychological distress represents a risk of peripheral vascular disease, abdominal aortic aneurysm, and heart failure [196,197]. Finally, the heart seems to play a surprising processing and decoding data role during intuition [198], a process by which information normally outside the range of conscious awareness is perceived by the psychophysiological systems [199].

In all aforementioned neurological and cardiovascular diseases, endothelial dysfunction is present $[200,201]$.

The brain-heart connection: The brain-heart connection represents a growing research field that is revolutionizing many of our past knowledge. Conventionally, the heart and brain are believed to be connected in a hierarchical way with the brain in the role of conductor (prefrontal cortex, mainly the right side) and the heart in the role of executor [202]. While intimate connection between the brain and the heart was enunciated by Claude Bernard over 150 years ago, only recently it has been proposed a model of neurovisceral integration able to explain the linkage between the cognitive-affective processing system and the autonomic nervous system [203]. A relationship is present between vagal tone and event-related potentials [204,205].

Biological systems are complex at multiple levels of temporal and spatial scales and consist of interconnected feedback loops. The Fourierbased spectral analysis averages the signals, so it cannot sufficiently display the nonlinear and non-stationary properties of complex biological systems [206]. Many complex and interesting phenomena in nature are due to nonlinear phenomena. The theory of nonlinear dynamical systems, also called 'chaos theory', has now progressed to a stage, where it becomes possible to study self-organization and pattern formation in the complex neuronal networks of the brain both in healthy conditions and in diseases [207,208]. A broad body of experimental work has demonstrated that apparently spontaneous brain activity is not random, being the so-called brain "resting-state networks" or "default mode network" closely related to the underlying anatomical and functional connectivity [209].

From this point of view, the hierarchical brain-heart interaction model should be reconsidered. Many regulatory processes and signals between the brain and the heart incorporate interactive feedforward and feedback mechanisms. Probably we should consider the whole as an integrated and synergistic system. The heart begins to beat before the brain is formed. A transplanted heart is not connected to the host nervous system but can immediately satisfy the physiological demands of its new host [210-212] .

Entropy measurement techniques, which compute the regularity patterns of a time series, provide quantitative connotations that facilitate comparisons and correlations between two systems and between individual subjects [213-215]. Starting from these considerations, Pei-Feng Lin et al. demonstrated close correlations between the signal complexity of cerebral and cardiac electrical activity [206]. This demonstration will open the way for further research aimed at clarifying the relationship between electromagnetic connection between the brain-heart axis and the entire body. Tofani et al. revealed that electromagnetic energy could be the key link between the world of atoms and the world of genetics and cells [216,217]. This could be therapeutically important since scientific evidence is emerging about the effects of electromagnetic energy in the treatment of cancers [218] and wound healing [219] .

J. Andrew Armour described the presence of a cardiac neuronal system [220] (Figure 4) in which the intrinsic cardiac ganglia and intrathoracic extracardiac ganglia can process information independently of the brain [221].

Taggart et al. recently reviewed the anatomical and functional relationships that link anger, emotions, arrhythmias and sudden death. Briefly, the sympathetic and parasympathetic activity is not only reciprocal with a simple see-saw effect where sympathetic stimulation is proarrythmic while enhanced parasympathetic tone is protective. A co-activation also occurs [160]. Furthermore, it seems that the heart is reached by autonomic input with different spatial and temporal patterns (the so-called "brain-heart laterality hypothesis" by Lane and Jennings [160,222]) (Figure 5) and that emotional processing in the cortex is conveyed ipsilaterally through the brainstem to the autonomic nerves which in turn are distributed asymmetrically in the ventricular myocardium [223-225]. In particular left sided neural signals reach the postero-inferor heart walls and the left ventricle and the right sided neural innervation the anterior wall and right ventricle, albeit with substantial overlap [160,222,226,227,228-230]. Moreover, Beau et al. showed an heterogeneous myocardial transmural distribution of betaadrenergic receptor subtypes [231]. Sympathetic and parasympathetic inputs to the heart are modulated by different reflexes rising from mechano- or chemo-receptors within the myocardium, blood vessels and lungs that send their signals not only to the brain vasomotor center but also involve higher brain centers of the medulla oblungata, in a dynamic interplay [160,232-236].

Different emotions are associated with different patterns of autonomic activity and different brain cortical representations [237239]. Clinical studies have identified anger as the most common emotion precipitating ventricular arrhythmia [240,241]. Several studies have demonstrated specific patterns of autonomic activity for 

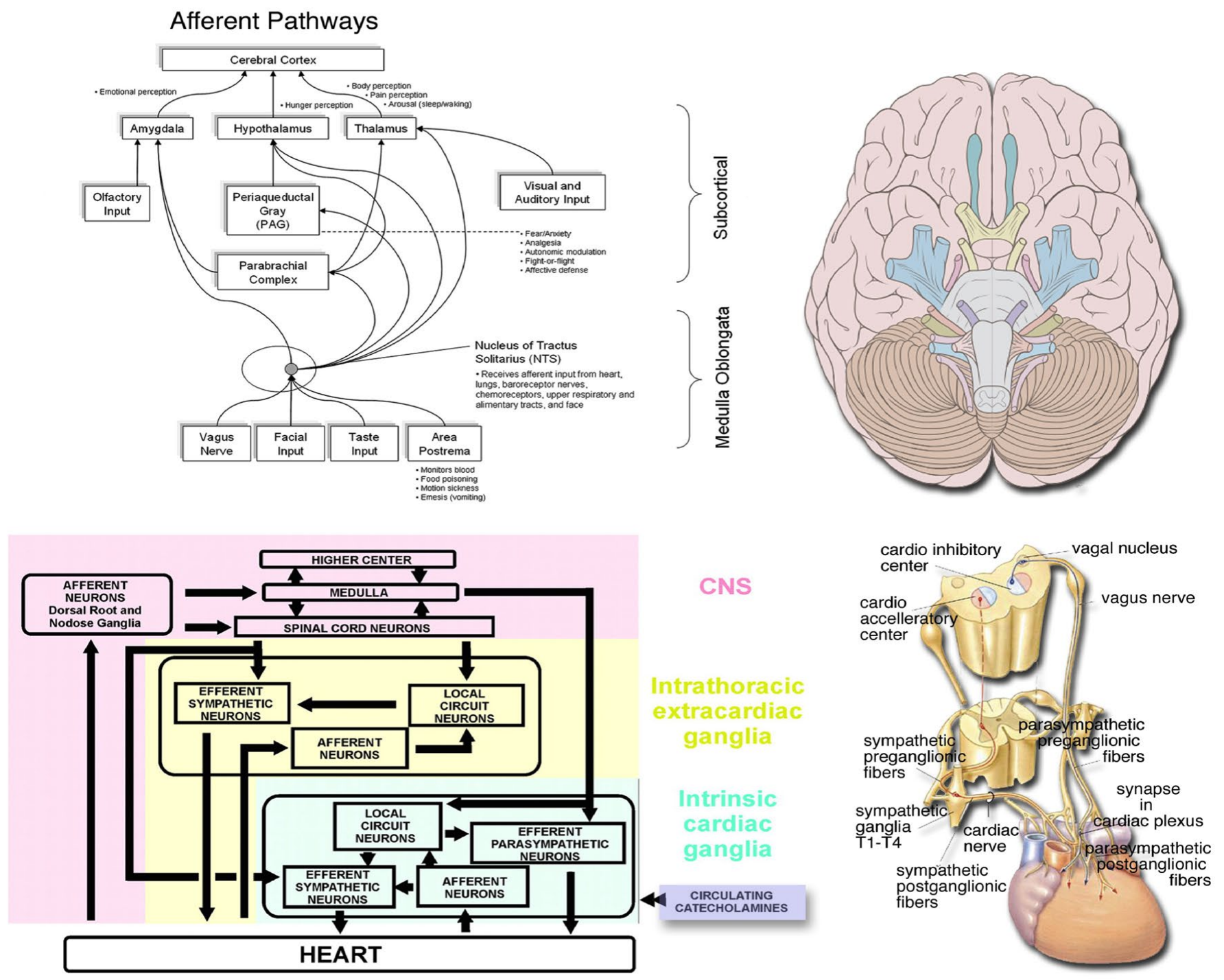

Figure 4. Neural control system of the heart, a hierarchy of three neuronal centers residing in central command, intrathoracic ganglia, and intrinsic cardiac ganglia: the dr. Armour's discovery [448]. The cardiac neuronal hierarchy can be represented as a massively parallel and, for the most part, stochastic control system such that stable cardiac control occurs in the absence of obvious cause and effect. This hierarchy displays robust external behavior while matching cardiac output to whole body blood flow demands. "The little brain on the heart" transduces centripetal and centrifugal inputs in the coordination of regional cardiac electrical and mechanical indices [448]. The regional cardiac mechano-sensory and chemosensory milieu is transduced by afferent neuronal somata located not only in nodose and dorsal root ganglia but also in intrathoracic intrinsic and extrinsic cardiac ganglia. This information engenders intrathoracic, as well as central (medullary and spinal cord) reflexes. The lower right-hand box indicates that circulating catecholamines influence cardiomyocytes not only directly but also indirectly via intrinsic cardiac adrenergic neurons [449]. While the main priority in central command is blood demand, the priority at the intrathoracic and cardiac levels is heart rate. As a result of this breakdown, heart rate becomes less predictable and therefore less reliable as a diagnostic guide as to the traumatic state of the heart, which it is commonly used as such following an ischemic event. On the basis of these results dr.Armour proposed that under the singular conditions of myocardial ischemia a determination of neural control indexes in addition to cardiovascular indexes has the potential of enhancing clinical outcome [450]. As shown in the top left part of the figure, cardiovascular afferents have connections to numerous brain centers involved in emotion and stress perception including the thalamus, hypothalamus, and amygdala.Ample evidence implicates anger together with other emotions and mental stress in playing a significant role in myocardial ischemia, arrhythmias and sudden death [157]. The mechanisms involved embrace neuroscience, physiology of the autonomic nervous system and cardiac electrophysiology which are usually investigated and reported by investigators from different disciplines. Growing evidence favors specific cortical representation of emotions in concert with autonomic reflexes and the molecular physiology of the myocardium. Feedback mechanisms from heart to brain probably play a significant modulatory role, particularly in pathological conditions. Such a highly interdependent schema could be regarded as a control system underlining the importance of an interdisciplinary approach to this field [160]. This is of paramount importance because standard drug therapy may not protect our patients from mental stress induced ischemia and its consequences [451]. Modified from [255,449]

anger and other emotions in response to emotional facial expressions [242,243], film clips [244], and to the recall of previous emotional experiences [239,245]. Rainville et al., using Fourier analysis of the ECG R-R tachogram (or "heart frequence-Heart Rate Variability" (HRV)), demonstrated that anger recall was associated with an increase in heart rate but no change in HRV, suggesting relative dominance of sympathetic activity [239]. In contrast fear, happiness, and sadness were associated with an increase in heart rate but a decrease in HRV (parasympathetic activity) suggesting an overall decrease in parasympathetic activity, or increase in sympathetic/parasympathetic ratio $[160,239]$.

Asymmetric autonomic neural traffic to the heart in response to emotion could be generated by several cortical upstream mechanisms. 


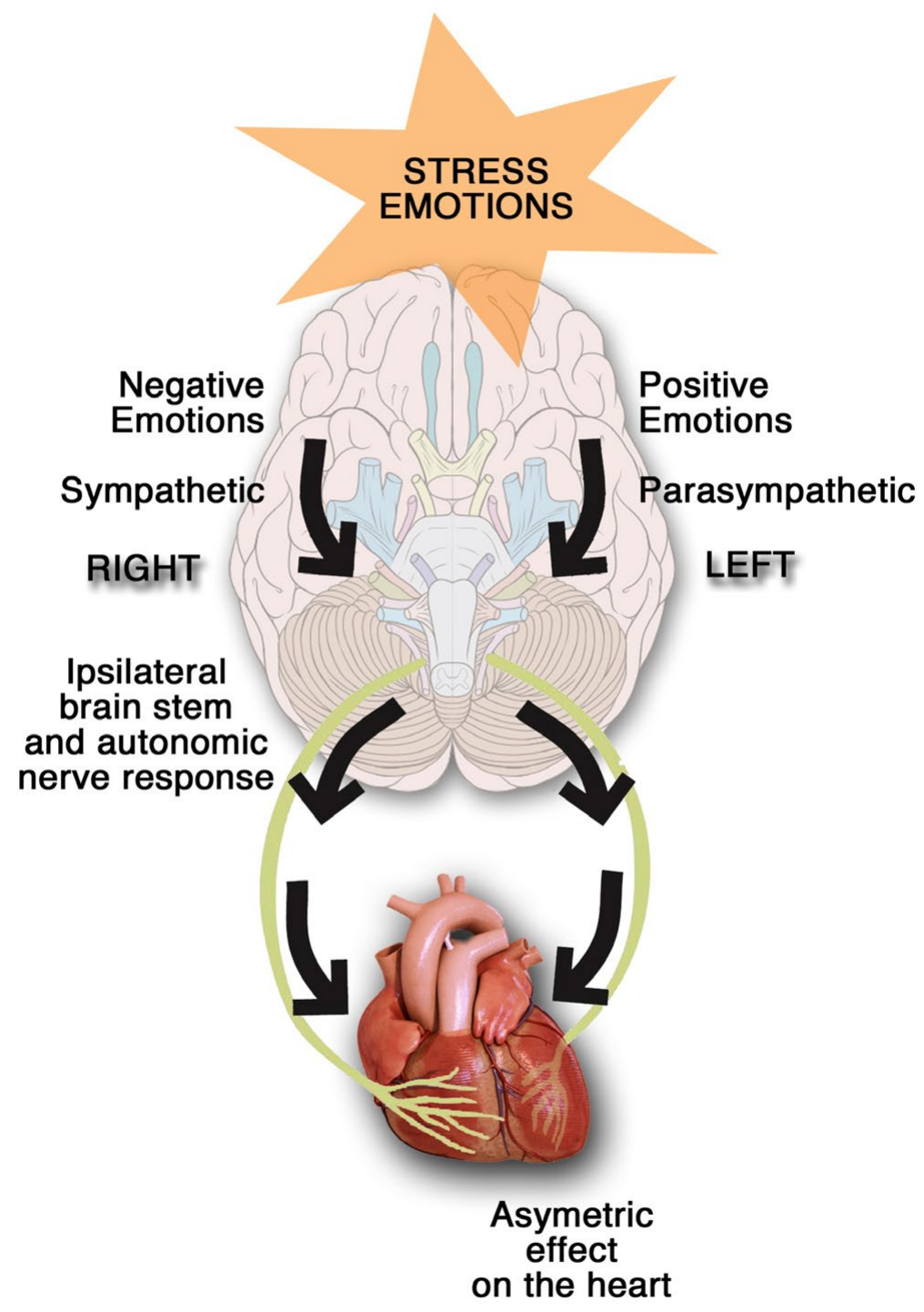

Figure 5. Brain-heart laterality theory [160]. Autonomic nerve traffic from the brain to the heart is mainly ipsilateral between the brainstem and heart. There is also some degree of lateralization of the distribution of the right and left autonomic nerves on the heart. These considerations form the basis for the laterality hypothesis whereby central neural processes may be represented asymmetrically on the heart and thereby induce inhomogeneous repolarization and be proarrhythmic. Modified from [160].

Considerable evidence suggests that the left and right halves of the human forebrain are associated differentially with specific emotions: positive emotions are associated to the left and negative emotions to the right hemisphere with specific neural pathways used for particular emotions [246]. As depicted in Figure 5, a similar lateralization is apparent for the cortical control of cardiac activity which may be related directly to predominantly sympathetic effects arising from the right hemisphere and predominantly parasympathetic effects arising from the left hemisphere [247-250].

On the other hand, cognitions and emotions can be influenced by bodily physiology [232]. Garfinkel et al. demonstrated that the cerebral processing of fear stimuli is selectively gated by their timing in relation to individual heartbeats, being amygdala responses greater to fearful stimuli presented at systole than that if presented in diastole [251]. The signals from the heart to the brain are then filtered by central limbic structures modulating the level of the signal to the cortex [252].

According to all these data, researches by McCraty et al. at the HeartMath Institute described that the communication pathways between the heart and brain occur through the generation and transmission of rhythms and patterns of activity that are related to cognitive and emotional function and self-regulatory capacity[253]. They showed that self-induced positive emotions increase the coherence in bodily processes, which is reflected in the pattern of the heart's rhythm [254,255]. It seems that heart beats form a rhythmic information code, that is perceived by the brain as a Morse code [256,257]. Aftanas et al. described a relationship between brain (alpha and theta waves) and heart oscillations (individual rate and blood pressure variability) $[258,259]$. The shift in the heart rhythm in turn plays an important role in facilitating higher cognitive functions, creating emotional stability and facilitating states of calm [260]. Over time, this establishes a new 
inner-baseline reference, a type of implicit memory that organizes perception, feelings, and behavior [198,199,261]. Without establishing a new baseline reference, people are at risk of getting "stuck" in familiar, yet unhealthy emotional and behavioral patterns and living their lives through the automatic filters of past familiar or traumatic experience [255]. Many studies confirm that cardiac timing influences memory and impacts cognitive functions [262]. Furthermore, physiological fluctuations in cardiovascular afferent information influence specific emotional judgments, mediated through regions including the periaqueductal gray matter, and shape evoked autonomic responses through engagement of orbitofrontal cortex [263].

Many cell types secrete small vesicles called exosomes, that are derived from multivesicular bodies and that can also form from endocytic-like lipid raft domains of the plasma membrane [264]. Secretory exosomes contain a characteristic composition of proteins, and a recent report indicates that mast cell exosomes harbor a variety of mRNAs and microRNAs as well [265]. Exosomes express cell recognition molecules on their surface that facilitate their selective targeting and uptake into recipient cells [264]. Smalheiser et al. described that cells within the central nervous system communicate transferring vesicles containing RNAs and proteins among themselves and with endothelial cells within the brain [266]. Then, neural exosomes may pass into the bloodstream reaching endothelial cells and immunitary cells [266].

As we already described, circulating miRNAs are protected by encapsulation in membrane-bound vesicles such as exosomes, but the majority of circulating miRNAs in human plasma and serum cofractionate with Argonaute2 (Ago2) protein, rather than with vesicles [141]. Changes in miRNA expression occurring in the brain and heart could have an impact on coexisting neurological and cardiovascular characteristics by modulating organ function, accentuating cellular stress, and impinging on neuronal and/or heart cell survival [143].

Finally, the brain and the heart dialogue also through the immune system. As a matter of fact, the brain and the immune system are the two major adaptive systems of the body and are nowadays considered as a single neuroimmunitary system [267-270]. Dysregulation of the autonomic system enhances the inflammatory response of the innate and adaptive immune systems leading to the initiation or acceleration of pathological processes and worsening increasing of cardiovascular risks [271]. In turns, the heart cells talk to immunitary cells directly [272274] and, being connected to the nervous system, probably through brain mediation. The heart releases hormones such as the natriuretic peptides (Atrial Natriuretic Peptide (ANP), Brain Natriuretic Peptide (BNP) and Cardiac Natriuretic Peptide (CNP)) and endogenous cardiac steroids that act as neurotransmitters or neuromodulators in the brain [275]. The same compounds are able to modulate lymphocyte reactions [276]. Finally, it is interesting to notice how brain, the immune system and the heart share similar mnemonic properties. We can remember past events or concepts through our brains; there is the memory of past infections in "memory lymphocytes" circulating in the blood, and finally there is an electrical memory within the heart as described by Ozgen and colleagues [277,278] and as is commonly found in clinical cardiologic practice in case of " $\mathrm{T}$ memory waves" after cardiac pacemaker stimulation. Figure 6 depicts the brain-heart dialogue.

\section{The connection between the heart, the endocrine and immune systems}

It 's already well known that the cardiovascular system is influenced by the activity of many hormones $[9,65,76]$ and of the immune system. Considering the cardiovascular system, we can find traces of the immune action in every disease, being involved in atherosclerosis [279] and myocardial ischemia/infarction [280,281], in heart valve calcification and stenosis progression [282] or heart valve endocarditis, in heart failure [283], aortic aneurysms [284], pericarditis, myocarditis and autoimmune heart pathologies [285] and even in congenital affections [286]. Furthermore, complement, a primordial sentinel of the innate immune response, engages in multiple inflammatory cascades and complement proteins have been implicated in tissue and organ regeneration including the cardiovascular system [287].

\section{The heart as a primary PNEI organ}

The heart, in addition to receiving all these PNEI influences, is itself a PNEI organ.

We have already seen how is actively involved in the psychoneurological processes.

The heart also acts as a gland: secreting atrial, brain and C-type natriuretic peptides (ANP [288], BNP and CNP [289]), mediates important cognitive functions in the brain [275,290] and regulates the immune system activity [276]. Moreover, anger and stress could cause an excess consumption of natriuretic peptides in nervous and cardiovascular system which inhibit their compensatory selfrepair action on atherosclerotic process, leading to fibrosis and lipid peroxidation and heart failure, as demonstrated in animals [291]. A failing heart also secretes adrenomedullin (ADM) which has a coronary vasodilatatory effect [292] and is involved in the cardiorenal signalling [293-295]. From epicardial adipose tissue are also produced and released the endocannaboinoids with a protective action on cardiac metabolism, atherosclerosis and possible ischemic injury [296]. Finally, the heart interacts bidirectionally with the immune system through numerous signals: ANP, BNP, cytokines, toll-like receptors 2 and 4 (TLR-2, TLR-4 [297-299]) etc.

\section{Endothelial cells in the PNEI network}

The coronary circulation endothelium is part of the endoderm, the largest endocrine organ in our body $[300,301]$. From this point of view it is easy to understand how it receives signals from neurotransmitters, hormones and cytokines, and in this way its function is regulated by the PNEI network [302]. This observation suggests that the PNEI-system equilbrium could be used as an ideal marker of endothelial health and therefore cardiovascular health [303]. For example, in order to explain the dynamics related to the onset of obesity and endothelial dysfunction, Yuan et al. observed the changes of vascular endothelial function and PNEI network molecules in case of hyper-alimentation diet in combination with restricting movement. Confort-based lifestyle, inducing changes of common PNEI chemical signal molecules, lead to vascular endothelial dysfunction [304].

We recently reviewed [65] the hormonal influences that act on the coronary endothelium, influencing its function and that can be studied through the evaluation of the CFR. In summary, on endothelial cells acts a real neuro-endocrine-immune symphony in which the melody is played by the vitamin D [305], parathyroid hormone (PTH) [32], reninangiotensin-aldosterone system (RAAS) $[195,306]$ axis in concert with 


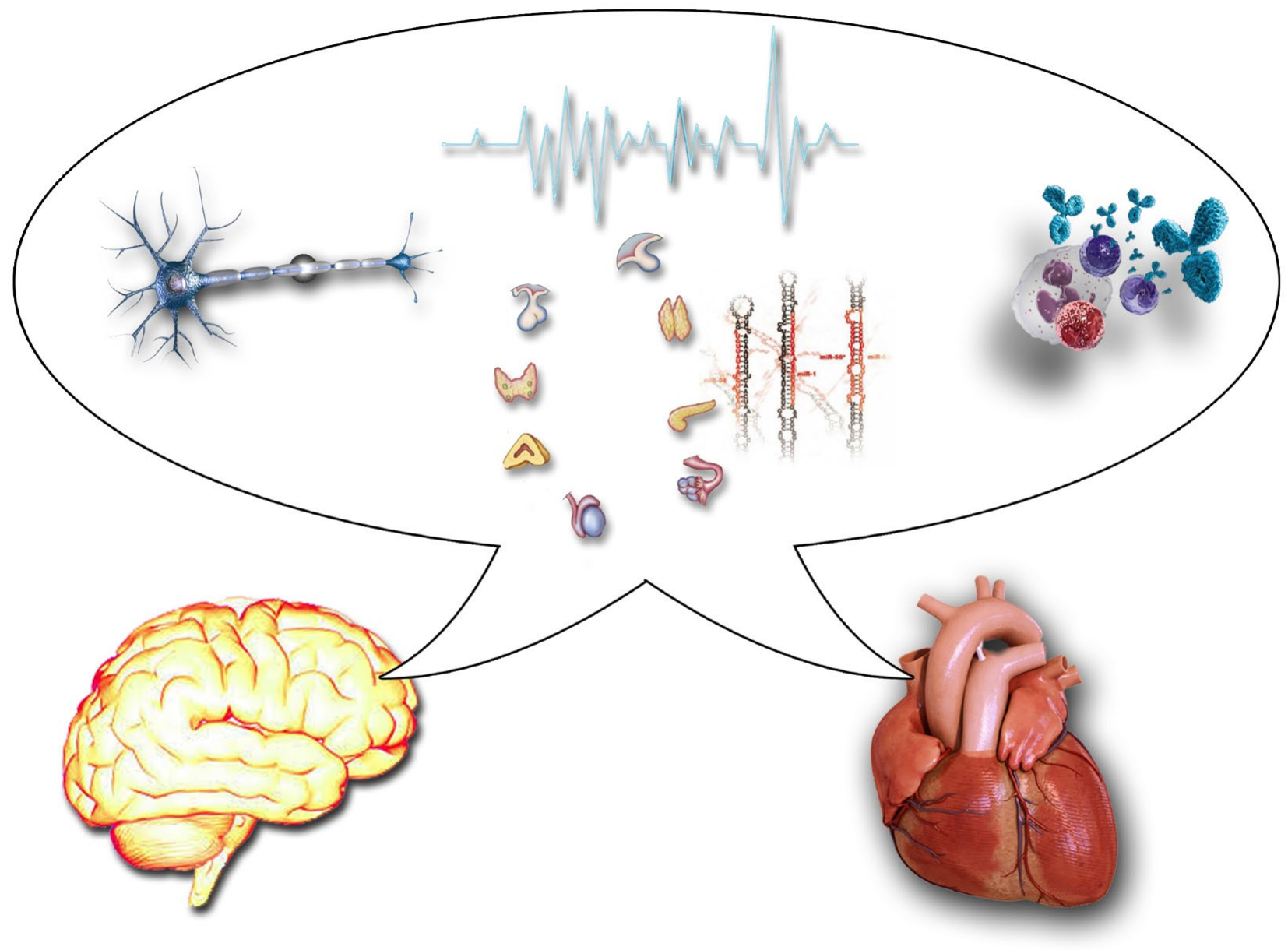

Figure 6. The brain-heart dialogue There is a dynamic, bidirectional communication between the heart and brain continuously influencing each ones functions [168,195,452]. The cardiovascular system communicates with the brain in four major ways: neurologically (through the direct transmission of nerve impulses), biochemically (via hormones, neurotransmitters, cytokines [453] and miRNAs [454]), biophysically (through pressure waves [172], baroreflexes [455,456], breathing patterns [233,457] and heart rhythms [198,199,252-255,261]) and energetically (through electromagnetic field interactions[206]). Based on relatively recent scientific discoveries, it seems that the heart is capable of mediating cognitive processes [206,251,458] and also possesses an intrinsic neurological activity [221] enough to be considered a "little pumping brain" or a part of the neurological system. On the other hand more and more clinical evidences are emerging about connections that bind neurological affections and the cardiovascular ones and vice versa [173,177,459]. The heart is also affected by the psychological balance of the human organism. In fact there are many demonstrations of how our emotions can trigger different types of cardiovascular events: the best known case is the Tako-tsubo syndrome or "stress cardiomyopathy" [460,461], but also arrhythmias and electrocardiographic changes [157,222,462,463], release of troponin in healthy subjects undergoing psychological stress [154] and myocardial infarction in case of outburst of anger [160,464,465].

thyroid and TSH hormones [307-310], GH and insulin like growth factor 1 (IGF-1) [311-313], cortisol and adreno-corticotropic hormone (ACTH) [314,315], sex hormones [316], insulin and glucagon like protein-1 (GLP-1) [317-320], adipokines [195,321-323], oxytocin and vasopressin [324-329], prolactin [330-333], melatonin [334-337], bilirubin, heme catabolic pathway, and gamma-glutamyltransferase [338-341].

Rounding out the orchestra is the immune system [62,342], with the familiar example of inflammation as a key process involved in the pathogenesis of atherosclerosis [323,343-348], the already discussed action of platelets and the autonomic balance, where the prevalence of the sympathetic system on the parasympathetic, is a determining factor for endothelial dysfunction [195].

From the point of neuro-endocrine-immune system view, we have shown how the fat in itself is not a cardiovascular risk factor, but it will become in the presence of inflammation (in turn linked to the presence of one or more stress factors) [322,323]. Peri-coronary adipose tissue, in the absence of stress, instead produces adipokines with vasoprotective effect (increased production of adiponectin compared to pro-inflammatory cytokines) [349,350]. Adipose tissue mediates important effects in the cardiovascular system and details of which are yet unknown. In particular, the endocannabinoid system is an interesting field of both pathophysiological and clinical research [351]. As explained by Hiley et al. "endocannabinoids, such as anandamide and 2-arachidonoylglycerol, are synthesized from membrane phospholipids in the heart and other cardiovascular tissues. They activate several epigenetic mechanisms [352] through cannabinoid CB1 and CB2 receptors, transient receptor potential V1 (TRPV1), peroxisome proliferator-activated receptors, and perhaps a novel vascular G-protein- 
coupled receptor. Inactivation is by cellular uptake and fatty acid amide hydrolase. Endocannabinoids relax coronary and other arteries and decrease cardiac work but seem not to be involved in tonic regulation of cardiovascular function. They act as a stress response system, which is activated, for example, in myocardial infarction and circulatory shock [353,354]. Endocannabinoids are largely protective [355,356]; they decrease tissue damage and arrhythmia[357,358] in myocardial infarction [359] and may reduce progression of atherosclerosis (CB2 receptor stimulation inhibits lesion progression), and fatty acid amide hydrolase knockout mice (which have enhanced endocannabinoid levels) show decreased cardiac dysfunction with age compared with wild types. However, endocannabinoids may mediate doxorubicin-induced cardiac dysfunction. Their signaling pathways are not fully elucidated but they can lead to changed expression of a variety of genes, including those involved in inflammatory responses [360-363]. There is potential for therapeutic targeting of endocannabinoids and their receptors, but their apparent involvement in both protective and deleterious actions on the heart means that careful risk assessment is needed before any treatment can be introduced [364,365]" [296]. As a PNEI mediator, the endocannabinoid anandamide is a lipid transmitter synthesized and released "on demand" by neurons in the brain and is also generated by macrophages where its endotoxin (LPS)-induced synthesis has been implicated in the hypotension of septic shock and advanced liver cirrhosis [366]. Endocannabinoid signaling processes are present in diverse organisms and in organisms 500 million years divergent in evolution and their relaxing action on vascular tone [354,367] is coupled to NO [368].

As briefly described in the introductory paragraphs, NO generated from L-arginine by NO synthase (NOS) has a pivotal role in regulating blood flow. In most vascular beds, the continuous generation of NO reduces basal vasomotor tone and increases blood flow. As such, local NOS inhibition, eg, with the non-isoform-selective inhibitor NG-monomethyl-L-arginine (L-NMMA), reduces resting blood flow both in animal studies and in humans [369]. These effects have generally been attributed to NO generated by endothelial NOS (eNOS) expressed in the endothelium of blood vessels. NO derived from eNOS also mediates increases in blood flow elicited by agonists such as acetylcholine and substance $\mathrm{P}$, and the impairment of such responses (known as endothelial dysfunction) predicts the development of atherosclerosis [16,370].

Recent data from animal studies indicate that NO generated by local neuronal NOS (nNOS) can influence vascular tone, raising the possibility that different NOS isoforms may subserve distinct effects on the regulation of blood flow [371]. These results were confirmed in humans, indicating that basal microvascular tone in healthy subjects in vivo is regulated by local nNOS-derived NO, whereas acetylcholinestimulated vasodilatation is eNOS mediated [372,373].

We can also consider the NO as PNEI molecule mediating multiple interactions between neuroendocrine and neuroimmune systems $[16,268,270,374-380]$ in physiological and pathological processes [200]. It plays an important role in creating and regulating the dialogue between the actors involved in our adaptation to the environment [381]. NO participates in signal transduction pathways that result in the release of corticosterone from the adrenal gland and nNOS modulates learning and memory and is involved in development of neuropsychiatric diseases, including depression [382]. Nitric oxide generated in response to stress exposure is associated with depressionlike and anxiety-like behaviours [74].
Especially noteworthy is the endothelial interaction with the immune system through TLR-2 and TLR-4. In particular the TLR4/ $\mathrm{NF \kappa B} / \mathrm{p} 38$ signaling pathway may lead to endothelial and $\mathrm{NO}$ impairment (through the decreased eNOS phosphorylation) [383]. This process can also occur in the course of mental stress [268] and may be associated with coronary and atrial thrombogenesis [384,385]. Moreover, systemic TLR2 and TLR4 response and expression decrease after percutaneous coronary interventions and TLR response is positively associated with coronary flow reserve, percentage diameter stenosis and presence of multivessel disease [386]. Toll-like receptors 2 and 4 modulate autonomic control of heart rate and energy metabolism [297].

We know that cigarette smoking and alcohol abuse are important cardiovascular risk factors [9]. What we have just described about the PNEI influences on endothelial function and on the dialogue between endothelium and immune system through TLR allows us to understand why. TLR-4 is an innate immune regulator of neuroimmune and neuroendocrine interactions in stress responses and could be activated either by exogenous pathogenic mechanisms, or as a result of endogenous stress signals [268]. As described by Vetreno et al., adolescence is a critical developmental stage of life during which the prefrontal cortex matures, and binge drinking and alcohol abuse are common. Recent studies have found that ethanol increases neuroinflammation through Toll-like receptors signaling, leading to persistent upregulation of innate immune danger signaling in the adult prefrontal cortex that correlates with adult neurocognitive dysfunction $[387,388]$. Furthermore, cigarette smoke induces TLR-4 expression and its inflammatory pathway in many districts [389]. A vast body of research attests to the adverse effects of alcohol [390,391] and chronic smoking [392,393] on cardiac, pulmonary, and vascular function as well as the increased risk for various forms of cancer [394]. Alcohol assumption and cigarette smoking are often associated and the common final inflammatory TLR-4 pathway with NO production impairment [395], could further explain their deleterious effects. Furthermore, the interactive pharmacological effects of nicotine and low doses of alcohol play an important role in motivating contemporaneous use and suggest roles for cross-reinforcement and cross-tolerance in the development and maintenance of alcohol and nicotine use and dependence [396]. Finally, we have to consider that both alcohol consuming and cigarette smoking are common behaviors in depressed or anxious people. Nowadays, we know that inflammation and cell-mediated immune activation are key factors in depression [187,397]. From all these data we can understand how alcohol and cigarette smoking, albeit giving a temporary relief, enslave the patient in harmful behaviors and thoughts. From this point of view, we have to appreciate legislations banning smoking in indoor public places and workplaces to protect the population from secondhand smoke exposure. Several studies have reported reductions in hospitalizations for acute coronary events following the enactment of smoke-free laws [398].

\section{References}

1. Lloyd-Jones D, Adams RJ, Brown TM, Carnethon M, Dai S, et al. (2010) Executive summary: Heart disease and stroke statistics-2010 update: A report from the american heart association. Circulation 121: 948-954. [Crossref]

2. Lerner DJ, Kannel WB (1986) Patterns of coronary heart disease morbidity and mortality in the sexes: a 26-year follow-up of the Framingham population. Am Heart $J$ 111: 383-390. [Crossref]

3. Nichols M, Townsend N, Scarborough P, Rayner M (2013) Cardiovascular disease in Europe: Epidemiological update. Eur. Heart J 34: 3028-3034. [Crossref] 
4. Okrainec K, Banerjee DK, Eisenberg MJ (2004) Coronary artery disease in the developing world. Am. Heart $J$ 148: 7-15. [Crossref]

5. Schneider RH, Grim CE, Rainforth M V., Kotchen T, Nidich SI, et al. (2012). Stress reduction in the secondary prevention of cardiovascular disease: Randomized, controlled trial of transcendental meditation and health education in blacks. Circ Cardiovasc Qual Outcomes 5: 750-758. [Crossref]

6. Duncker DJ, Bache RJ (2008) Regulation of coronary blood flow during exercise. Physiol Rev 88: 1009-1086.

7. Duncker DJ, Bache RJ, Merkus D (2012) Regulation of coronary resistance vessel tone in response to exercise. J Mol Cell Cardiol 52: 802-813. [Crossref]

8. Bianco JA, Alpert JS (1997) Physiologic and clinical significance of myocardial blood flow quantitation: what is expected from these measurements in the clinical ward and in the physiology laboratory? Cardiology 88: 116-126. [Crossref]

9. Camm AJ, Luscher TF, Serruys PW (2009) ESC Textbook of Cardiovascular Medicine Second Edition. Oxford Med: 1-1398.

10. Schelbert HR (2010) Anatomy and physiology of coronary blood flow. J Nucl Cardio 17: 545-554. [Crossref]

11. Muller JM, Davis MJ, Chilian WM (1996) Integrated regulation of pressure and flow in the coronary microcirculation. Cardiovasc Res 32: 668-78 . [Crossref]

12. Herrmann J, Kaski JC, Lerman A (2012) Coronary microvascular dysfunction in the clinical setting: From mystery to reality. Eur. Heart J 33: 2771-81. [Crossref]

13. Camici PG, Crea F (2007) Coronary microvascular dysfunction. N Engl J Med 356: 830-40. [Crossref]

14. Van Beek JH. Is local metabolism the basis of the fractal vascular structure in the heart? Int J Microcirc Clin Exp 17: 337-45. [Crossref]

15. Herrmann J, Lerman A (2001) The endothelium: Dysfunction and beyond. J Nucl Cardiol 8: 197-206. [Crossref]

16. Sitia S, Tomasoni L, Atzeni F, Ambrosio G, Cordiano C, et al. (2010) From endothelial dysfunction to atherosclerosis. Autoimmun Rev 9: 830-4. [Crossref]

17. Crea F, Camici PG, Merz CNB (2014) Coronary microvascular dysfunction: An update. Eur Heart J 35: 1101-11. [Crossref]

18. Tona F, Caforio ALP, Montisci R, Gambino A, Angelini A, et al. (2006)Coronary flow velocity pattern and coronary flow reserve by contrast-enhanced transthoracic echocardiography predict long-term outcome in heart transplantation. Circulation 114: I49-55 Crossref]

19. Flammer AJ, Lüscher TF (2010) Three decades of endothelium research: from the detection of nitric oxide to the everyday implementation of endothelial function measurements in cardiovascular diseases. Swiss Med Wkly. [Crossref]

20. Tona F, Caforio ALP, Iliceto S (2007) Microvascular dysfunction in left apical ballooning syndrome: Primary cause or secondary phenomenon? Eur J Echocardiogr. [Crossref]

21. Furchgott RF, Zawadzki J V (1980) The obligatory role of endothelial cells in the relaxation of arterial smooth muscle by acetylcholine. Nature 288: 373-376. . [Crossref]

22. Cosentino F, Lüscher TF (1995) Maintenance of vascular integrity: role of nitric oxide and other bradykinin mediators. Eur Heart J Suppl K: 4-12. [Crossref]

23. Edwards G, Félétou M, Weston AH (2010) Endothelium-derived hyperpolarising factors and associated pathways: A synopsis. Pflugers Arch Eur J Physiol 459: 863-79. [Crossref]

24. Osto E, Tona F, De Bon E, Iliceto S, Cella G (2010). Endothelial dysfunction in cardiac allograft vasculopathy: potential pharmacological interventions. Curr Vasc Pharmacol 8: 169-88. [Crossref]

25. Palmer RM, Ashton DS, Moncada S (1988) Vascular endothelial cells synthesize nitric oxide from L-arginine. Nature 333: 664-666. [Crossref]

26. Moncada S, Higgs EA (1993) The 1-Arginine: Nitric Oxide Pathway. $N$ Engl J Med 329: 2002-2012. [Crossref]

27. Flammer AJ, Anderson T, Celermajer DS, Creager MA, Deanfield J, et al. (2012) The assessment of endothelial function: from research into clinical practice. Circulation 126: 753-767. [Crossref]

28. Hirata K, Amudha K, Elina R, Hozumi T, Yoshikawa J, et al. (2004) Measurement of coronary vasomotor function: getting to the heart of the matter in cardiovascular research. Clin Sci (Lond) 107: 449-460. [ Crossref]
29. Leschke M, Motz W, Strauer BE (1986) Hemorheologic therapy applications in coronary heart disease. Wien Med Wochenschr 136 Spec N: 17-24. [Crossref]

30. Meimoun P, Tribouilloy C (2008) Non-invasive assessment of coronary flow and coronary flow reserve by transthoracic Doppler echocardiography: a magic tool for the real world. Eur J Echocardiogr 9: 449-457. [Crossref]

31. Buus NH, Bøttcher M, Hermansen F, Sander M, Nielsen TT, et al. (2001) Influence of nitric oxide synthase and adrenergic inhibition on adenosine-induced myocardial hyperemia. Circulation 104: 2305-2310. [Crossref]

32. Osto E, Fallo F, Pelizzo MR, Maddalozzo A, Sorgato N, et al. (2012) Coronary microvascular dysfunction induced by primary hyperparathyroidism is restored after parathyroidectomy. Circulation 126: 1031-1039. [Crossref]

33. Van den Heuvel AF, van Veldhuisen DJ, van der Wall EE, Blanksma PK, Siebelink $\mathrm{HM}$, et al. (2000) Regional myocardial blood flow reserve impairment and metabolic changes suggesting myocardial ischemia in patients with idiopathic dilated cardiomyopathy. J Am Coll Cardiol 35: 19-28. [Crossref]

34. Bohlen HG (2006) Nitric oxide and the cardiovascular system. Compr Physiol 5: 808823. [Crossref]

35. Tona F (2006) Dilated cardiomyopathy and coronary flow reserve. Eur Heart $J 27$ author reply 1884-5. [Crossref]

36. Vecchiati A, Tellatin S, Angelini A, Iliceto S, Tona F (2014) Coronary microvasculopathy in heart transplantation: Consequences and therapeutic implications. World J Transplant 4: 93-101. [Crossref]

37. Rubinshtein R, Yang EH, Rihal CS, Prasad A, Lennon RJ, et al. (2010) Coronary microcirculatory vasodilator function in relation to risk factors among patients without obstructive coronary disease and low to intermediate Framingham score. Eur Heart J 31: 936-942. [Crossref]

38. Kothawade K, Bairey Merz CN (2011) Microvascular coronary dysfunction in women pathophysiology, diagnosis, and management. Curr Probl Cardiol 36: 291-318. [Crossref]

39. Anderson TJ, Gerhard MD, Meredith IT, Charbonneau F, Delagrange D, et al. (1995) Creager MA, Selwyn AP, Ganz P. Systemic nature of endothelial dysfunction in atherosclerosis. Am J Cardiol 75: 71B - 74B. [Crossref]

40. Besedovsky H, Sorkin E (1977) Network of immune-neuroendocrine interactions. Clin Exp Immunol 27: 1-12. [Crossref]

41. Steinhoff M, Ständer S, Seeliger S, Ansel JC, Schmelz M, et al. (2003) Modern aspects of cutaneous neurogenic inflammation. Arch Dermatol 139: 1479-1488

42. Luger TA, Brzoska T, Scholzen TE, Kalden DH, Sunderkötter C, et al. (2000). The role of alpha-MSH as a modulator of cutaneous inflammation. Ann N Y Acad Sci: 917 232-238. [Crossref]

43. Slominski A, Wortsman J, Luger T, Paus R, Solomon S (2000) Corticotropin releasing hormone and proopiomelanocortin involvement in the cutaneous response to stress. Physiol Rev 80: 979-1020. [Crossref]

44. Epel ES, Burke HM, Wolkowitz OM (2007) The Psychoneuroendocrinology of Aging Anabolic and Catabolic Hormones. In: Handbook of health psychology and aging: 119-41.

45. Wilder RL (2002) Neuroimmunoendocrinology of the rheumatic diseases: past, present, and future. Ann N Y Acad Sci 966: 13-19. [Crossref]

46. Zhang J, Ma T, Li Y, Li S. dbNEI2.0 (2008) : Building multilayer network for drugNEI-disease. Bioinformatics 24: 2409-2411. [Crossref]

47. Zhuang Y, Li S, Li Y. dbNEI (2006) A specific database for neuro-endocrine-immune interactions. Neuroendocrinol Lett 27: 53-59. [Crossref]

48. Besedovsky HO, Del Rey A (2007). Physiology of psychoneuroimmunology: a personal view. Brain Behav Immun 21: 34-44. [Crossref]

49. Besedovsky HO, del Rey A (1996) Immune-neuro-endocrine interactions: facts and hypotheses. Endocr Rev 17: 64-102. [Crossref]

50. Besedovsky HO, del Rey A (2011) Central and peripheral cytokines mediate immunebrain connectivity. Neurochem Res 36: 1-6.

51. Del Rey A, Wolff C, Wildmann J, Randolf A, Straub RH, et al. (2010) When immuneneuro-endocrine interactions are disrupted: experimentally induced arthritis as an example. Neuroimmunomodulation 17: 165-168. [Crossref]

52. Ader R. Psychoneuroimmunology, Two-Volume Set. Elsevier; 2011: 1-1269.

53. Ader R, Cohen N, Felten D (1995) Psychoneuroimmunology: interactions between the nervous system and the immune system. Lancet 345: 99-103. [Crossref] 
54. Chrousos GP, Gold PW (1992) The concepts of stress and stress system disorders. Overview of physical and behavioral homeostasis. JAMA 267: 1244-1252. [Crossref]

55. Ader R, Cohen N (1975) Behaviorally conditioned immunosuppression. Psychosom Med 37: 333-340. [Crossref]

56. Perdrizet GA (1997)Hans Selye and beyond: responses to stress. Cell Stress Chaperones 2: 214-219. [Crossref]

57. Vicennati V, Garelli S, Rinaldi E, Di Dalmazi G, Pagotto U, et al. (2014) Pasquali R. Cross-talk between adipose tissue and the HPA axis in obesity and overt hypercortisolemic states. Horm Mol Biol Clin Investig 17: 63-77. [Crossref]

58. Dantzer R(2001) Cytokine-induced sickness behavior: mechanisms and implications. Ann N Y Acad Sci 933: 222-234. [Crossref]

59. Vollmer-Conna U (2001) Acute sickness behaviour: an immune system-to-brain communication? Psychol Med 31: 761-767. [Crossref]

60. Frieri M (2003) Neuroimmunology and inflammation: implications for therapy of allergic and autoimmune diseases. Ann Allergy Asthma Immunol 90: 34-40. [Crossref]

61. Kop WJ (2003) The integration of cardiovascular behavioral medicine and psychoneuroimmunology: New developments based on converging research fields. Brain Behav Immun: 17: 233-237. [Crossref]

62. Pittman QJ (2011) A Neuro-Endocrine-Immune Symphony. J Neuroendocrinol 23: 1296-1297. [Crossref]

63. Szabo S, Tache Y, Somogyi A (2012) The legacy of Hans Selye and the origins of stress research: a retrospective 75 years after his landmark brief 'letter' to the editor of nature. Stress 15: 472-478. [Crossref]

64. Chrousos GP (2009) Stress and disorders of the stress system. Nat Rev Endocrinol 5 374-81. [Crossref]

65. Dal Lin C, Tona F, Osto E (2015) Coronary Microvascular Function and Beyond : The Crosstalk between Hormones, Cytokines, and Neurotransmitters. Int $J$ Endocrinol. [Crossref]

66. Allen AP, Kennedy PJ, Cryan JF, Dinan TG, Clarke G (2014) Biological and psychological markers of stress in humans: focus on the Trier Social Stress Test. Neurosci Biobehav Rev 38: 94-124. [Crossref]

67. Chrousos GP (1997) Stressors, stress, and neuroendocrine integration of the adaptive response. The 1997 Hans Selye Memorial Lecture. In: Annals of the New York Academy of Sciences: $311-35$

68. Stratakis CA, Chrousos GP (1995) Neuroendocrinology and pathophysiology of the stress system. Ann N Y Acad Sci 771: 1-18. [Crossref]

69. Tsigos C, Chrousos GP (2002) Hypothalamic-pituitary-adrenal axis, neuroendocrine factors and stress. J Psychosom Res 53: 865-71. [Crossref]

70. Black PH(2002) Stress and the inflammatory response: A review of neurogenic inflammation. Brain. Behav. Immun 16: 622-653. [Crossref]

71. Redmond N, Richman J, Gamboa CM, Albert MA, Sims M, et al. (2013) Perceived stress is associated with incident coronary heart disease and all-cause mortality in lowbut not high-income participants in the Reasons for Geographic And Racial Differences in Stroke study. J Am Heart Assoc 2: e000447. [Crossref]

72. Can MM, Guler G, Guler E, Ozveren O, Turan B, et al. (2015) Enhanced platelet reactivity in pediatric depression: an observational study. Blood Coagul Fibrinolysis. [Crossref]

73. Matsuhisa F, Kitamura N, Satoh E (2014) Effects of acute and chronic psychological stress on platelet aggregation in mice. Stress 17: 186-192. [Crossref]

74. Ormonde do Carmo MBO, Mendes-Ribeiro AC, Matsuura C, Pinto VL, et al. (2015) Major depression induces oxidative stress and platelet hyperaggregability. $J$ Psychiatr Res 61: 19-24. [Crossref]

75. Bourgault C, Bergeron S, Bogaty P, Poirier P (2006) A most unusual acute coronary syndrome. Can J Cardiol 22: 429-432. [Crossref]

76. Gustafsson BI, Hauso O, Drozdov I, Kidd M, Modlin IM (2008) Carcinoid heart disease. Int J Cardiol 129: 318-324. [Crossref]

77. Olivier B. Serotonin (2015) A never-ending story. Eur J Pharmacol: 753: 2-18. [Crossref]

78. Duerschmied D, Suidan GL, Demers M, Herr N, Carbo C, et al. (2013) Platele serotonin promotes the recruitment of neutrophils to sites of acute inflammation in mice. Blood 121: 1008-1015. [Crossref]
79. Trzeciak-Ryczek A, Tokarz-Deptuła B, Deptuła W (2013) Platelets--an important element of the immune system. Pol J Vet Sci 16: 407-413. [Crossref]

80. Baganz NL, Blakely RD (2013) A dialogue between the immune system and brain, spoken in the language of serotonin. ACS Chem Neurosci 4: 48-63. [Crossref]

81. Cocchi M, Tonello L, Gabrielli F, Pregnolato M (2011) Depression, osteoporosis, serotonin and cell membrane viscosity between biology and philosophical anthropology. Ann Gen Psychiatry 10: 9. [Crossref]

82. Cocchi M, Tonello L (2010) Bio molecular considerations in major depression and ischemic cardiovascular disease. Cent Nerv Syst Agents Med Chem 10: 97-107. [Crossref]

83. Cocchi M, Tonello L, Lercker G. (2010) Fatty acids, membrane viscosity, serotonin and ischemic heart disease. Lipids Health Dis 9: 97. [Crossref]

84. Epel ES, Blackburn EH, Lin J, Dhabhar FS, Adler NE, Morrow JD, et al. (2004) Accelerated telomere shortening in response to life stress. Proc Natl Acad Sci U S A 101: 17312-17315. [Crossref]

85. Bajpai A, Verma AK, Srivastava M, Srivastava R (2014) Oxidative stress and major depression. J Clin Diagn Res 8: CC04-7. [Crossref]

86. Heitzer T, Schlinzig T, Krohn K, Meinertz T, Munzel T, et al. (2001) Endothelia dysfunction, oxidative stress, and risk of cardiovascular events in patients with coronary artery disease. Circulation 104: 2673-8. [Crossref]

87. Miyashita T, Yamaguchi T, Motoyama K, Unno K, Nakano Y, et al. (2006) Socia stress increases biopyrrins, oxidative metabolites of bilirubin, in mouse urine. Biochem Biophys Res Commun: 349: 775-780. [Crossref]

88. Yamaguchi T, Shioji I, Sugimoto A, Yamaoka M (2002) Psychological stress increases bilirubin metabolites in human urine. Biochem Biophys Res Commun 293: 517-520. [Crossref]

89. Miyaoka T, Yasukawa R, Yasuda H, Shimizu M, Mizuno S, et al. (2004) Urinary excretion of biopyrrins, oxidative metabolites of bilirubin, increases in patients with psychiatric disorders. Eur Neuropsychopharmacol 15: 249-52. [Crossref]

90. Shioji I (2005) Oxidative stress related diseases and biopyrrins. Rinsho Byori 53: 155159. [Crossref]

91. Kundur AR, Singh I, Bulmer AC (2014) Bilirubin, platelet activation and heart disease: A missing link to cardiovascular protection in Gilbert's syndrome? Atherosclerosis 239: 73-84. [Crossref]

92. Bulmer AC, Verkade HJ, Wagner K-H (2013) Bilirubin and beyond: a review of lipid status in Gilbert's syndrome and its relevance to cardiovascular disease protection Prog Lipid Res 52: 193-205. [Crossref]

93. Bulmer AC, Blanchfield JT, Toth I, Fassett RG, Coombes JS (2007) Improved resistance to serum oxidation in Gilbert's syndrome: a mechanism for cardiovascular protection. Atherosclerosis 199: 390-396. [Crossref]

94. Charmandari E, Tsigos C, Chrousos G(2005) Endocrinology of the stress response. Annu Rev Physiol 67: 259-284. [Crossref]

95. Elenkov IJ, Chrousos GP (2006). Stress system--organization, physiology and immunoregulation. Neuroimmunomodulation 13: 257-267. [Crossref]

96. Chrousos GP, Gold PW (1992) The concepts of stress and stress system disorders Overview of physical and behavioral homeostasis. JAMA 267: 1244-1252. [Crossref]

97. Alevizos M, Karagkouni A, Panagiotidou S, Vasiadi M, Theoharides TC (2014) Stress triggers coronary mast cells leading to cardiac events. Ann Allergy Asthma Immunol 112: 309-316. [Crossref]

98. Crick F (1970) Central dogma of molecular biology. Nature 227: 561-563. [Crossref]

99. Choudhuri S (2011) From Waddington's epigenetic landscape to small noncoding RNA: some important milestones in the history of epigenetics research. Toxicol Mech Methods 21: 252-74. [Crossref]

100. Kim M-S, Pinto SM, Getnet D, Nirujogi RS, Manda SS, et al. (2014) A draft map of the human proteome. Nature 509: 575-581. [Crossref]

101. Tollefsbol TO (2010) Epigenetics: The new science of genetics. In: Handbook of Epigenetics. Elsevier 2010: 1-624.

102. Heijmans BT, Tobi EW, Stein AD, Putter H, Blauw GJ, et al. (2008) Persistent epigenetic differences associated with prenatal exposure to famine in humans. Proc Natl Acad Sci U S A 105: 17046-17049. [Crossref] 
103. Boland MR, Shahn Z, Madigan D, Hripcsak G, Tatonetti NP (2015) Birth Month Affects Lifetime Disease Risk: A Phenome-Wide Method. J Am Med Informatics Assoc 1-15. [Crossref]

104. Hansen D, Lou HC, Olsen J. Serious life events and congenital malformations: a national study with complete follow-up. Lancet 356: 875-880. [Crossref]

105. Wainstock T, Lerner-Geva L, Glasser S, Shoham-Vardi I, Anteby EY (2013) Prenatal stress and risk of spontaneous abortion. Psychosom Med 75: 228-235. [Crossref]

106. Latendresse G, Ruiz RJ (2011) Maternal corticotropin-releasing hormone and the use of selective serotonin reuptake inhibitors independently predict the occurrence of preterm birth. J Midwifery Womens Health 56: 118-126. [Crossref]

107. Weaver ICG, Cervoni N, Champagne FA, D'Alessio AC, Sharma S, et al. (2004) Epigenetic programming by maternal behavior. Nat Neurosci 7: 847-854. [Crossref]

108. Ackerman JP, Riggins T, Black MM (2010) A review of the effects of prenatal cocaine exposure among school-aged children. Pediatrics 125: 554-565. [Crossref]

109. Entringer S, Epel ES, Kumsta R, Lin J, Hellhammer DH, et al. (2011) Stress exposure in intrauterine life is associated with shorter telomere length in young adulthood. Proc Natl Acad Sci U S A 108: E513-E518. [Crossref]

110. Bagot RC, Zhang T-Y, Wen X, Nguyen TTT, Nguyen H-B, et al. (2012)Variations in postnatal maternal care and the epigenetic regulation of metabotropic glutamate receptor 1 expression and hippocampal function in the rat. Proc Natl Acad Sci U S A 109 Suppl: 17200-17207. [Crossref]

111. Borghol N, Suderman M, Mcardle W, Racine A, Hallett M, et al. (2012) Associations with early-life socio-economic position in adult DNA methylation. Int $J$ Epidemiol 41: 62-74. [Crossref]

112. Fraga MF, Ballestar E, Paz MF, Ropero S, Setien F, et al. (2005) Epigenetic differences arise during the lifetime of monozygotic twins. Proc Natl Acad Sci U S A 102: 10604-10609. [Crossref]

113. Miyake K, Yang C, Minakuchi Y, Ohori K, Soutome M, et al. (2013) Comparison of Genomic and Epigenomic Expression in Monozygotic Twins Discordant for Rett Syndrome. PLoS One. [Crossref]

114. McGowan PO, Meaney MJ, Szyf M (2008) Diet and the epigenetic (re)programming of phenotypic differences in behavior. Brain Res 1237: 12-24. [Crossref]

115. Dauncey MJ (2013) Genomic and epigenomic insights into nutrition and brain disorders. Nutrients: 887-914. [Crossref]

116. Mirza S, Sharma G, Parshad R, Gupta SD, Pandya P, et al. (2013). Expression of DNA methyltransferases in breast cancer patients and to analyze the effect of natural compounds on DNA methyltransferases and associated proteins. J Breast Cancer 16: 23-31. [Crossref]

117. Nakajima K, Takeoka M, Mori M, Hashimoto S, Sakurai A, et al. (2010) Exercise effects on methylation of ASC gene. Int J Sports Med 31: 671-675. [Crossref]

118. J. David Sweatt, Michael J. Meaney, Eric Nestler SA. (2014) Epigenetic Regulation in the Nervous System, 1st Edition Acad. Press. Elsevier, Amsterdam 2013.

119. Covington HE, Vialou VF, LaPlant Q, Ohnishi YN, Nestler EJ (2011) Hippocampaldependent antidepressant-like activity of histone deacetylase inhibition. Neurosci Lett 493: 122-126. [Crossref]

120. Meloni M (2014) The social brain meets the reactive genome: neuroscience, epigenetics and the new social biology. Front Hum Neurosci 8: 309. [Crossref]

121. Wang Y, He Z, Zhao C, Li L (2013) Medial amygdala lesions modify aggressive behavior and immediate early gene expression in oxytocin and vasopressin neurons during intermale exposure. Behav Brain Res 245: 42-9. [Crossref]

122. Jindal V, Gupta S, Das R (2013) Molecular mechanisms of meditation. Mol. Neurobiol 48: 808-811. [Crossref]

123. Kaliman P, Lvarez-Lopez MJ, Cosn-Tomas M, Rosenkranz MA, Lutz A, et al. (2014). Rapid changes in histone deacetylases and inflammatory gene expression in expert meditators. Psychoneuroendocrinology 40: 96-107. [Crossref]

124. Crews D, Gore AC, Hsu TS, Dangleben NL, Spinetta M, et al. (2007) Transgenerational epigenetic imprints on mate preference. Proc Natl Acad Sci U S A: 104: 5942-5946. [Crossref]

125. Skinner MK, Manikkam M, Guerrero-Bosagna C (2011) Epigenetic transgenerational actions of endocrine disruptors. Reprod Toxicol 31: 337-343. [Crossref]

126. Rodgers AB, Morgan CP, Bronson SL, Revello S, Bale TL (2013) Paternal stress exposure alters sperm microRNA content and reprograms offspring HPA stress axis regulation. J Neurosci 33: 9003-9012. [Crossref]

127. Morgan HD, Santos F, Green K, Dean W, Reik W (2005) Epigenetic reprogramming in mammals. Hum Mol Genet 14 Spec No: R47-58. [Crossref]

128. Kaati G, Bygren LO, Pembrey M, Sjöström M (2007) Transgenerational response to nutrition, early life circumstances and longevity. Eur J Hum Genet 15: 784-790. [Crossref]

129. Gapp K, von Ziegler L, Tweedie-Cullen RY, Mansuy IM (2014) Early life epigenetic programming and transmission of stress-induced traits in mammals: how and when can environmental factors influence traits and their transgenerational inheritance? Bioessays 36: 491-502. [Crossref]

130. Rehan VK, Liu J, Sakurai R, Torday JS (2013) Perinatal nicotine-induced transgenerational asthma. Am J Physiol Lung Cell Mol Physiol 305: L501-L507. [Crossref]

131. Lee DS, Park J, Kay KA, Christakis NA, Oltvai ZN, et al. (2008) The implication of human metabolic network topology for disease comorbidity. Proc Natl Acad Sci US A. [Crossref]

132. Park J, Lee D-S, Christakis NA, Barabási A-L (2009) The impact of cellular networks on disease comorbidity. Mol Syst Biol. [Crossref]

133. McEachin RC, Keller BJ, Saunders EFH, McInnis MG (2008) Modeling gene-byenvironment interaction in comorbid depression with alcohol use disorders via an integrated bioinformatics approach. BioData Min 1: 2. [Crossref]

134. Lee RC, Feinbaum RL, Ambros V (1993) The C. elegans heterochronic gene lin4 encodes small RNAs with antisense complementarity to lin-14. Cell 75: 843-854. [Crossref]

135. Ambros V (2004) The functions of animal microRNAs. Nature 431: 350-355. [Crossref]

136. Katoh MC (2014) ardio-miRNAs and onco-miRNAs: circulating miRNA-based diagnostics for non-cancerous and cancerous diseases. Front cell Dev Biol 2: 61. [Crossref]

137. Hébert SS, De Strooper B (2009) Alterations of the microRNA network cause neurodegenerative disease. Trends Neurosci 32: 199-206. [Crossref]

138. Mehler MF (2008) Epigenetic principles and mechanisms underlying nervous system functions in health and disease. Prog Neurobiol 86: 305-41. [Crossref]

139. Zhu H, Fan G-C (2011) Extracellular/circulating microRNAs and their potential role in cardiovascular disease. Am J Cardiovasc Dis 1: 138-49. [Crossref]

140. Gupta SK, Bang C, Thum T (2010) Circulating MicroRNAs as biomarkers and potential paracrine mediators of cardiovascular disease. Circ Cardiovasc Genet 3 : 484-488. [Crossref]

141. Russo F, Di Bella S, Nigita G, Macca V, Laganà A, et al. (2012) Giugno R, Pulvirenti A, Ferro A. miRandola: Extracellular Circulating MicroRNAs Database. PLoS One 7. [Crossref]

142. Bronze-da-Rocha E (2014) MicroRNAs Expression Profiles in Cardiovascular Diseases. Biomed Res Int. [Crossref]

143. Hébert SS (2009) Putative Role of MicroRNA-Regulated Pathways in Comorbid Neurological and Cardiovascular Disorders. Cardiovasc Psychiatry Neurol. [Crossref]

144. Alexiou P, Maragkakis M, Papadopoulos GL, Reczko M, Hatzigeorgiou AG (2008) Lost in translation: an assessment and perspective for computational microRNA target identification. Bioinformatics 25: 3049-55. [Crossref]

145. Mendell JT, Olson EN (2012) MicroRNAs in stress signaling and human disease. Cell 148: 1172-1187. [Crossref]

146. Wightman B, Ha I, Ruvkun G (1993) Posttranscriptional regulation of the heterochronic gene lin-14 by lin-4 mediates temporal pattern formation in C. elegans. Cell 75: 855-862. [Crossref]

147. Goldstein DS (2012) Neurocardiology: therapeutic implications for cardiovascular disease. Cardiovasc Ther 30: e89-106. [Crossref]

148. Goldstein DS (2013) Concepts of scientific integrative medicine applied to the physiology and pathophysiology of catecholamine systems. Compr Physiol 3: 1569 1610

149. Szczepanska-Sadowska E (2008) Role of neuropeptides in central control of cardiovascular responses to stress. J Physiol Pharmacol 59: 61-89. [Crossref] 
150. Chatterjee S (2011) ECG changes in subarachnoid haemorrhage: A synopsis. Netherlands Hear J 19: 31-34. [Crossref]

151. Kukla P, Jastrzebski M, Praefort W (2012) J-wave-associated ventricular fibrillation in a patient with a subarachnoid haemorrhage. Europace 14: 1063-1064. [Crossref]

152. Gibbons DD, Southerland EM, Hoover DB, Beaumont E, Armour JA, et al. (2012) Neuromodulation targets intrinsic cardiac neurons to attenuate neuronally mediated atrial arrhythmias. Am J Physiol Regul Integr Comp Physiol 302: R357-R364. [Crossref]

153. Kop WJ, Krantz DS, Nearing BD, Gottdiener JS, Quigley JF, et al. (2004) Effects of acute mental stress and exercise on T-wave alternans in patients with implantable cardioverter defibrillators and controls. Circulation 109: 1864-1869. [Crossref]

154. Lazzarino AI, Hamer M, Gaze D, Collinson P, Steptoe A (2013) The association between cortisol response to mental stress and high-sensitivity cardiac troponin $\mathrm{T}$ plasma concentration in healthy adults. J Am Coll Cardiol 62: 1694-1701. [Crossref]

155. Borjigin J, Lee U, Liu T, Pal D, Huff S, Klarr D, et al. (2013) Surge of neurophysiological coherence and connectivity in the dying brain. Proc Natl Acad Sci US A 110: 14432-1437. [Crossref]

156. Frommeyer G, Eckardt L, Breithardt G (2013) Panic attacks and supraventricular tachycardias: The chicken or the egg? Netherlands Hear J 21: 74-77. [Crossref]

157. Taggart P (2013) Brain-heart interactions and cardiac ventricular arrhythmias. Netherlands Hear J 21: 78-81. [Crossref]

158. Postema PG, Wiersma JJ, Bilt IAC, Dekkers P, Bergen PFMM (2012) Takotsubo cardiomyopathy shortly following pacemaker implantation — case report and review of the literature. Netherlands Hear J. [Crossref]

159. Li AH, Hsu KL, Liau CS, Tseng YZ, Lee YT (2000) Amyotrophic lateral sclerosis with a 'pseudo-infarction' pattern on the electrocardiograph. A case report. Cardiology 93: 133-136. [Crossref]

160. Taggart P, Boyett MR, Logantha S, Lambiase PD (2011) Anger, emotion, and arrhythmias: from brain to heart. Front Physiol 2: 67. [Crossref]

161. Haugaa KH, Vestervik TT, Andersson S, Amlie JP, Jørum E, et al. (2013) Abnormal electroencephalograms in patients with long QT syndrome. Heart Rhythm 10: 1877 1883. [Crossref]

162. Bakovic M, Juric Paic M, Zdrilic E, Vukojevic K, Ferhato, et al. (2013) Changes in cardiac innervation during maturation in long-term diabetes. Exp Gerontol 48: 14731478. [Crossref]

163. Cardinal R, Pagé P, Vermeulen M, Bouchard C, Ardell JL, Foreman RD, et al. (2006) Spinal cord stimulation suppresses bradycardias and atrial tachyarrhythmias induced by mediastinal nerve stimulation in dogs. Am J Physiol Regul Integr Comp Physiol 291. [Crossref]

164. Southerland EM, Milhorn DM, Foreman RD, Linderoth B, DeJongste MJL, et al. (2007). Preemptive, but not reactive, spinal cord stimulation mitigates transient ischemia-induced myocardial infarction via cardiac adrenergic neurons. Am J Physiol Heart Circ Physiol 292: H311-H317. [Crossref]

165. Ajijola OA, Yagishita D, Reddy NK, Yamakawa K, Vaseghi M, et al. (2015) Remodeling of Stellate Ganglion Neurons following Spatially Targeted Myocardial Infarction: Neuropeptide And Morphologic Changes. Heart Rhythm. [Crossref]

166. Bruggemans EF (2013) Cognitive dysfunction after cardiac surgery: Pathophysiological mechanisms and preventive strategies. Neth Heart J 2013: 21: 70-73. [Crossref]

167. Plaschke K, Fichtenkamm P, Schramm C, Hauth S, Martin E, et al. (2010). Early postoperative delirium after open-heart cardiac surgery is associated with decreased bispectral EEG and increased cortisol and interleukin-6. Intensive Care Med 36: 20812089. [Crossref]

168. van der Wall EE, van Gilst WH (2013) Neurocardiology: close interaction between heart and brain. Neth Heart J 21: 51-52. [Crossref]

169. Piepoli MF (2013) Exercise training in chronic heart failure: mechanisms and therapies. Neth Heart J 21: 85-90. [Crossref]

170. McMurray JJ V, Adamopoulos S, Anker SD, Auricchio A, Böhm M, et al. (2012) ESC Guidelines for the diagnosis and treatment of acute and chronic heart failure 2012: The Task Force for the Diagnosis and Treatment of Acute and Chronic Heart Failure 2012 of the European Society of Cardiology. Developed in collaboration with the Heart. Eur Heart J 33: 1787-847. [Crossref]

171. Zhang J, Yu X, Xie D (2010) Effects of mental tasks on the cardiorespiratory synchronization. Respir Physiol Neurobiol 170: 91-95. [Crossref]
172. Masuki S, Nose H (2009) Increased cerebral activity suppresses baroreflex control of heart rate in freely moving mice. $J$ Physiol 587: 5783-5794. [Crossref]

173. Tipre DN, Goldstein DS (2005) Cardiac and extracardiac sympathetic denervation in Parkinson's disease with orthostatic hypotension and in pure autonomic failure. $\mathrm{J} \mathrm{Nucl}$ Med 46: 1775-1781. [Crossref]

174. Goldstein DS, Kopin IJ, Sharabi Y (2014) Catecholamine autotoxicity. Implications for pharmacology and therapeutics of Parkinson disease and related disorders. Pharmacol Ther 144: 268-282. [Crossref]

175. Francis GS, Bartos JA, Adatya S (2014) Inotropes. J Am Coll Cardiol 63: 2069-2078. [Crossref]

176. Cermakova P, Eriksdotter M, Lund LH, Winblad B, Religa P, et al. (2015) Heart failure and Alzheimer's disease. J Intern Med 277: 406-425. [Crossref]

177. Cermakova P, Lund LH, Fereshtehnejad SM, et al. (2015) Heart failure and dementia: survival in relation to types of heart failure and different dementia disorders. Eur $J$ Heart Fail 17: 612-619. [Crossref]

178. Jalbert JJ, Daiello LA, Lapane KL (2008) Dementia of the Alzheimer type. Epidemio Rev 30: 15-34. [Crossref]

179. Caballol N, Martí MJ, Tolosa E (2007) Cognitive dysfunction and dementia in Parkinson disease. Mov Disord 22 Suppl 17: S358-S366. [Crossref]

180. Aarsland D, Kurz MW (2010) The epidemiology of dementia associated with Parkinson disease. J Neurol Sci 289: 18-22. [Crossref]

181. Aarsland D, Påhlhagen S, Ballard CG, Ehrt U, Svenningsson P (2011) Depression in Parkinson disease--epidemiology, mechanisms and management. Nat Rev Neurol 8: 35-47. [Crossref]

182. Barber R1 (2011) Inflammatory signaling in Alzheimer disease and depression. Cleve Clin J Med 78 Suppl 1: S47-S49. [Crossref]

183. Wint D1 (2011) Depression: a shared risk factor for cardiovascular and Alzheimer disease. Cleve Clin J Med 78 Suppl 1: S44-S46. [Crossref]

184. Sun X, Steffens DC, Au R, Folstein M, Summergrad P, et al. (2008) Amyloidassociated depression: a prodromal depression of Alzheimer disease? Arch Gen Psychiatry 65: 542-550. [Crossref]

185. Peters ME, Vaidya V, Drye LT, Rosenberg PB, Martin BK, et al. (2011) Sertraline for the treatment of depression in Alzheimer disease: genetic influences. $J$ Geriat Psychiatry Neurol 24: 222-228. [Crossref]

186. Blume J, Douglas SD, Evans DL (2011) Immune suppression and immune activation in depression. Brain Behav Immun25: 221-229. [Crossref]

187. Dantzer R, O'Connor JC, Freund GG, Johnson RW, Kelley KW (2008) From inflammation to sickness and depression: when the immune system subjugates the brain. Nat Rev Neurosci 9: 46-56. [Crossref]

188. Maes M, Berk M, Goehler L, Song C, Anderson G, et al. (2012) Depression and sickness behavior are Janus-faced responses to shared inflammatory pathways. BMC Med 10: 66. [Crossref]

189. Li W, Ling S, Yang Y, Hu Z2, Davies H, et al. (2014) Systematic hypothesis for post-stroke depression caused inflammation and neurotransmission and resultant on possible treatments. Neuro Endocrinol Lett 35: 104-109. [Crossref]

190. Dantzer R, Kelley KW (2007) Twenty years of research on cytokine-induced sickness behavior. Brain Behav Immun 21: 153-160. [Crossref]

191. Schins A, Honig A, Crijns H, Baur L, Hamulyák K (2003) Increased coronary events in depressed cardiovascular patients: 5-HT2A receptor as missing link? Psychosom Med 65: 729-737. [Crossref]

192. Grissom GR, Phillips RA (2005) Screening for depression: this is the heart of the matter. Arch Intern Med 165: 1214-1216. [Crossref]

193. Wei J, Pimple P, Shah AJ, Rooks C, Bremner JD, et al. (2014) Depressive symptoms are associated with mental stress-induced myocardial ischemia after acute myocardia infarction. PLoS One 9: e102986. [Crossref]

194. Halaris A (2013) Inflammation, heart disease, and depression. Curr Psychiatry Rep 15 : 40. [Crossref]

195. Pereira VH, Cerqueira JJ, Palha JA, Sousa N (2013) Stressed brain, diseased heart: a review on the pathophysiologic mechanisms of neurocardiology. Int J Cardiol 166 : 30-37. [Crossref] 
196. Batty GD, Russ TC, Stamatakis E, Kivimäki M (2014) Psychological distress and risk of peripheral vascular disease, abdominal aortic aneurysm, and heart failure: pooling of sixteen cohort studies. Atherosclerosis 236: 385-388. [Crossref]

197. Rozanski A, Blumenthal JA, Kaplan J (1999) Impact of psychological factors on the pathogenesis of cardiovascular disease and implications for therapy. Circulation 99 : 2192-2217. [Crossref]

198. McCraty R, Atkinson M, Bradley RT (2004) Electrophysiological evidence of intuition: part 1. The surprising role of the heart. J Altern Complement Med 10: 133143.. [Crossref]

199. McCraty R, Atkinson M, Bradley RT (2004) Electrophysiological evidence of intuition: Part 2. A system-wide process? J Altern Complement Med 10: 325-336. [Crossref]

200. Garry PS, Ezra M, Rowland MJ, Westbrook J, Pattinson KT (2015) The role of the nitric oxide pathway in brain injury and its treatment--from bench to bedside. Exp Neurol 263: 235-243. [Crossref]

201. Cahill-Smith S, Li JM (2014) Oxidative stress, redox signalling and endothelial dysfunction in ageing-related neurodegenerative diseases: a role of NADPH oxidase 2. Br J Clin Pharmacol 78: 441-453. [Crossref]

202. Benarroch EE (1993) The central autonomic network: functional organization, dysfunction, and perspective. Mayo Clin Proc 68: 988-1001. [Crossref]

203. Thayer JF, Lane RD (2009) Claude Bernard and the heart-brain connection: further elaboration of a model of neurovisceral integration. Neurosci Biobehav Rev 33: 81-88. [Crossref]

204. Dufey M, Hurtado E, Fernández AM, Manes F, Ibáñez A (2011) Exploring the relationship between vagal tone and event-related potentials in response to an affective picture task. Soc Neurosci 6: 48-62. [Crossref]

205. Leppänen PH, Guttorm TK, Pihko E, Takkinen S, Eklund KM, et al. (2004) Maturational effects on newborn ERPs measured in the mismatch negativity paradigm. Exp Neurol 190 Suppl 1: S91-S101. [Crossref]

206. Lin P-F, Lo M-T, Tsao J, Chang Y-C, Lin C, et al. (2014) Correlations between the signal complexity of cerebral and cardiac electrical activity: a multiscale entropy analysis. PLoS One 9: e87798. [Crossref]

207. Stam CJ (2005) Nonlinear dynamical analysis of EEG and MEG: review of an emerging field. Clin Neurophysiol 116: 2266-2301. [Crossref]

208. Ivanov PC, Amaral LA, Goldberger AL, Havlin S, Rosenblum MG, et al. (1999) Multifractality in human heartbeat dynamics. Nature 399: 461-465. [Crossref]

209. Deco G, Jirsa VK, McIntosh AR (2011) Emerging concepts for the dynamical organization of resting-state activity in the brain. Nat Rev Neurosci 12: 43-56. [Crossref]

210. Bernardi L, Keller F, Sanders M, Reddy PS, Griffith B, et al. (1989) Respiratory sinus arrhythmia in the denervated human heart. J Appl Physiol (1985) 67: 1447-1455. [Crossref]

211. Ordway GA, Charles JB, Randall DC, Billman GE, Wekstein DR (1982) Heart rate adaptation to exercise training in cardiac-denervated dogs. $J$ Appl Physiol Respir Environ Exerc Physiol 52: 1586-1590. [Crossref]

212. Mettauer B, Levy F, Richard R, Roth O, Zoll J, et al. (2005) Exercising with a denervated heart after cardiac transplantation. Ann Transplant 10: 35-42. [Crossref]

213. Pincus SM, Gladstone IM, Ehrenkranz RA (1991) A regularity statistic for medical data analysis. J Clin Monit 7: 335-345. [Crossref]

214. Richman JS, Moorman JR (2000) Physiological time-series analysis using approximate entropy and sample entropy. Am J Physiol Heart Circ Physiol 278: H2039-2049. [Crossref]

215. Costa M, Goldberger AL, Peng CK (2002) Multiscale entropy analysis of complex physiologic time series. Phys Rev Lett 89: 068102. [Crossref]

216. Tofani S (2015) Electromagnetic energy as a bridge between atomic and cellular levels in the genetics approach to cancer treatment. Curr Top Med Chem 15: 572-578. [Crossref]

217. Kumar S, Nirala JP, Behari J, Paulraj R (2014) Effect of electromagnetic irradiation produced by $3 \mathrm{G}$ mobile phone on male rat reproductive system in a simulated scenario. Indian J Exp Biol 52: 890-897. [Crossref]

218. Durak ZE, Büber S, Kocaoğlu EH, Öztürk B (2015) Static magnetic field inhibits 5 ' nucleotidase activity in cancerous and non-cancerous human gastric tissues. Electromagn Biol Med. [Crossref]
219. Saliev T, Mustapova Z, Kulsharova G, Bulanin D, Mikhalovsky S (2014) Therapeutic potential of electromagnetic fields for tissue engineering and wound healing. Cell Prolif 47: 485-493. [Crossref]

220. Armour JA1 (2004) Cardiac neuronal hierarchy in health and disease. Am J Physiol Regul Integr Comp Physiol 287: R262-R271. [Crossref]

221. Armour JA (2011) Physiology of the intrinsic cardiac nervous system. Heart Rhythm 8: 739. [Crossref]

222. Critchley HD, Taggart P, Sutton PM, Holdright DR, Batchvarov V, et al. (2005) Mental stress and sudden cardiac death: asymmetric midbrain activity as a linking mechanism. Brain 128: 75-85. [Crossref]

223. Kawano H, Okada R, Yano K (2003) Histological study on the distribution of autonomic nerves in the human heart. Heart Vessels 18: 32-39. [Crossref]

224. Paton JF, Boscan P, Pickering AE, Nalivaiko E (2005) The yin and yang of cardiac autonomic control: vago-sympathetic interactions revisited. Brain Res Brain Res Rev 49: 555-565. [Crossref]

225. Chen LS, Zhou S, Fishbein MC, Chen PS (2007) New perspectives on the role of autonomic nervous system in the genesis of arrhythmias. J Cardiovasc Electrophysiol 18: 123-127. [Crossref]

226. Levy MN, Ng M, Martin P, Zieske H (1966) Sympathetic and Parasympathetic Interactions upon the Left Ventricle of the Dog. Circ Res 19: 5-10.

227. Levy MN, Ng ML, Zieske H (1966) Functional distribution of the peripheral cardiac sympathetic pathways. Circ Res 19: 650-661. [Crossref]

228. Colivicchi F, Bassi A, Santini M, Caltagirone C (2004) Cardiac autonomic derangement and arrhythmias in right-sided stroke with insular involvement. Stroke 35: 2094-2098. [Crossref]

229. Johnson TA, Gray AL, Lauenstein JM, Newton SS, Massari VJ (2004) Parasympathetic control of the heart. I. An interventriculo-septal ganglion is the major source of the vagal intracardiac innervation of the ventricles. $J$ Appl Physiol 96: 2265-2272. [Crossref]

230. Zaffran S, Kelly RG, Meilhac SM, Buckingham ME, Brown NA (2004) Right ventricular myocardium derives from the anterior heart field. Circ Res 95: 261-268. [Crossref]

231. Beau SL, Tolley TK, Saffitz JE (1993) Heterogeneous transmural distribution of betaadrenergic receptor subtypes in failing human hearts. Circulation 88: 2501-2509. [Crossref]

232. Bernardi L, Porta C, Spicuzza L, Sleight P (2005) Cardiorespiratory interactions to external stimuli. Arch Ital Biol 143: 215-221. [Crossref]

233. Bernardi L, Passino C, Wilmerding V, Dallam GM, Parker DL, et al. (2001) Breathing patterns and cardiovascular autonomic modulation during hypoxia induced by simulated altitude. J Hypertens 19: 947-958. [Crossref]

234. Mason H, Vandoni M, Debarbieri G, Codrons E, Ugargol V, et al. (2013) Cardiovascular and respiratory effect of yogic slow breathing in the yoga beginner: what is the best approach? Evid Based Complement Alternat Med 2013: 743504. [Crossref]

235. Bernardi L, Porta C, Sleight P (2006) Cardiovascular, cerebrovascular, and respiratory changes induced by different types of music in musicians and non-musicians: the importance of silence. Heart 92: 445-452. [Crossref]

236. Bernardi L, Porta C, Casucci G, Balsamo R, Bernardi NF, et al. (2009) Dynamic interactions between musical, cardiovascular, and cerebral rhythms in humans. Circulation 119: 3171-3180. [Crossref]

237. Harrison NA, Gray MA, Gianaros PJ, Critchley HD (2010) The embodiment of emotional feelings in the brain. J Neurosci 30: 12878-12884. [Crossref]

238. Altenmüller E, Schürmann K, Lim VK, Parlitz D (2002) Hits to the left, flops to the right: different emotions during listening to music are reflected in cortical lateralisation patterns. Neuropsychologia 40: 2242-2256. [Crossref]

239. Rainville P, Bechara A, Naqvi N, Damasio AR (2006) Basic emotions are associated with distinct patterns of cardiorespiratory activity. Int $J$ Psychophysiol 61: 5-18. [Crossref]

240. Lampert R, Joska T, Burg MM, Batsford WP, McPherson CA, et al. (2002) Emotional and physical precipitants of ventricular arrhythmia. Circulation 106: 1800-1805. [Crossref] 
241. Burg MM, Lampert R, Joska T, Batsford W, Jain D (2004) Psychological traits and emotion-triggering of ICD shock-terminated arrhythmias. Psychosom Med 66: 898902. [Crossref]

242. Ekman P, Levenson RW, Friesen WV (1983) Autonomic nervous system activity distinguishes among emotions. Science 221: 1208-1210. [Crossref]

243. Levenson RW, Ekman P, Friesen WV (1990) Voluntary facial action generates emotion-specific autonomic nervous system activity. Psychophysiology 27: 363-384. [Crossref]

244. Christie IC, Friedman BH (2004) Autonomic specificity of discrete emotion and dimensions of affective space: a multivariate approach. Int J Psychophysiol 51: 143153. [Crossref]

245. Rainville P, Naqvi N, Long J, Bechara A (2000) Distinct body states associated with self-evoked basic emotions. Soc Neurosci Abstr 26.

246. Craig AD1 (2005) Forebrain emotional asymmetry: a neuroanatomical basis? Trends Cogn Sci 9: 566-571. [Crossref]

247. Wittling W, Block A, Genzel S, Schweiger E (1998) Hemisphere asymmetry in parasympathetic control of the heart. Neuropsychologia 36: 461-468. [Crossref]

248. Diedrich A, Porta A, Barbic F, Brychta RJ, Bonizzi P, et al. (2009) Lateralization of expression of neural sympathetic activity to the vessels and effects of carotic baroreceptor stimulation. Am J Physiol Heart Circ Physiol 296: H1758-1765. [Crossref]

249. Robinson BF, Epstein SE, Beiser GD, Braunwald E (1966) Control of heart rate by the autonomic nervous system. Studies in man on the interrelation between baroreceptor mechanisms and exercise. Circ Res 19: 400-411. [Crossref]

250. Lane RD, Wallace JD, Petrosky PP, Schwartz GE, Gradman AH (1992) Supraventricular tachycardia in patients with right hemisphere strokes. Stroke 23: 362-366. [Crossref]

251. Garfinkel SN, Minati L, Gray MA, Seth AK, Dolan RJ, et al. (2014) Fear from the heart: sensitivity to fear stimuli depends on individual heartbeats. J Neurosci 34: 65736582. [Crossref]

252. MacKinnon S, Gevirtz R, McCraty R, Brown M (2013) Utilizing heartbeat evoked potentials to identify cardiac regulation of vagal afferents during emotion and resonant breathing. Appl Psychophysiol Biofeedback 38: 241-255. [Crossref]

253. Tiller WA, McCraty R, Atkinson M (1996) Cardiac coherence: a new, noninvasive measure of autonomic nervous system order. Altern Ther Health Med 2: 52-65. [Crossref]

254. Shaffer F, McCraty R, Zerr CL1 (2014) A healthy heart is not a metronome: an integrative review of the heart's anatomy and heart rate variability. Front Psychol 5: 1040. [Crossref]

255. McCraty R, Zayas MA (2014) Cardiac coherence, self-regulation, autonomic stability, and psychosocial well-being. Front Psychol 5: 1090. [Crossref]

256. Rolls ET, Treves A (2011) The neuronal encoding of information in the brain. Prog Neurobiol 95: 448-490. [Crossref]

257. Stanley GB (2013) Reading and writing the neural code. Nat Neurosci 16: 259-263. [Crossref]

258. Aftanas LI, Brak IV, Gilinskaia OM, Pavlov SV, Reva NV (2014) Features of brain oscillatory activity and cardiac defense in treatment arterial hypertensives. Ross Fiziol Zh Im I M Sechenova 100: 112-127. [Crossref]

259. Aftanas LI, Brak IV, Reva NV, Pavlova SV (2013) Brain oscillations and individual variability of cardiac defense in human. Ross Fiziol Zh Im I M Sechenova 99: 13421356. [Crossref]

260. Dockray S, Steptoe A (2010) Positive affect and psychobiological processes. Neurosci Biobehav Rev 35: 69-75. [Crossref]

261. Atkinson RM (1999) Influence of afferent cardiovascular input on cognitive performance and alpha activity. Proc Annu Meet Pavlov Soc NY 1: 1-13.

262. Garfinkel SN, Barrett AB, Minati L, Dolan RJ, Seth AK, et al. (2013) What the heart forgets: Cardiac timing influences memory for words and is modulated by metacognition and interoceptive sensitivity. Psychophysiology 50: 505-512. [Crossref]

263. Gray MA, Beacher FD, Minati L, Nagai Y, Kemp AH, et al. (2012) Emotional appraisal is influenced by cardiac afferent information. Emotion 12: 180-191. [Crossref]

264. Boyle J. Molecular biology of the cell, 5th edition by B. Alberts, A. Johnson, J. Lewis, M. Raff, K. Roberts, and P. Walter. Garland Sciences, 2008: 1-1392.
265. Smalheiser NR (2007) Exosomal transfer of proteins and RNAs at synapses in the nervous system. Biol Direct 2: 35. [Crossref]

266. Smalheiser NR (2009) Do Neural Cells Communicate with Endothelial Cells via Secretory Exosomes and Microvesicles? Cardiovasc Psychiatry Neurol 2009: 383086. [Crossref]

267. Matzinger P (1998) An innate sense of danger. Semin Immunol 10: 399-415. [Crossref]

268. Liu J, Buisman-Pijlman F, Hutchinson MR (2014) Toll-like receptor 4: innate immune regulator of neuroimmune and neuroendocrine interactions in stress and major depressive disorder. Front Neurosci 8: 309. [Crossref]

269. Coogan AN, Wyse CA (2008) Neuroimmunology of the circadian clock. Brain Res 1232: 104-112. [Crossref]

270. Bellinger DL, Millar BA, Perez S, Carter J, Wood C, et al. (2008) Sympathetic modulation of immunity: relevance to disease. Cell Immunol 252: 27-56. [Crossref]

271. Abboud FM, Harwani SC, Chapleau MW (2012) Autonomic neural regulation of the immune system: implications for hypertension and cardiovascular disease. Hypertension 59: 755-762. [Crossref]

272. Naviaux RK (2014) Metabolic features of the cell danger response. Mitochondrion 16: 7-17. [Crossref]

273. Kinet V, Halkein J, Dirkx E, Windt LJ (2013) Cardiovascular extracellular microRNAs: emerging diagnostic markers and mechanisms of cell-to-cell RNA communication. Front Genet 4: 214. [Crossref]

274. Neppl RL, Wang DZ (2014) The myriad essential roles of microRNAs in cardiovascular homeostasis and disease. Genes Dis 1: 18-39. [Crossref]

275. Hodes A, Lichtstein D (2014) Natriuretic hormones in brain function. Front Endocrinol (Lausanne) 5: 201. [Crossref]

276. de Bold ML, Etchepare A, Martinuk A, de Bold AJ (2010) Cardiac hormones ANF and BNP modulate proliferation in the unidirectional mixed lymphocyte reaction. $J$ Heart Lung Transplant 29: 323-326. [Crossref]

277. Özgen N, Lu Z, Boink GJ, Lau DH, Shlapakova IN, et al. (2012) Microtubules and angiotensin II receptors contribute to modulation of repolarization induced by ventricular pacing. Heart Rhythm 9: 1865-1872. [Crossref]

278. Ozgen N, Rosen MR (2009) Cardiac memory: a work in progress. Heart Rhythm 6 564-570. [Crossref]

279. Ross R (1999) Atherosclerosis--an inflammatory disease. N Engl J Med 340: 115-126. [Crossref]

280. Arslan F, de Kleijn DP, Pasterkamp G (2011) Innate immune signaling in cardiac ischemia. Nat Rev Cardiol 8: 292-300. [Crossref]

281. de Haan JJ, Smeets MB, Pasterkamp G, Arslan F (2013) Danger signals in the initiation of the inflammatory response after myocardial infarction. Mediators Inflamm 2013: 206039. [Crossref]

282. Abdelbaky A, Corsini E, Figueroa AL, Subramanian S, Fontanez S, et al. (2015) Early aortic valve inflammation precedes calcification: a longitudinal FDG-PET/CT study. Atherosclerosis 238: 165-172. [Crossref]

283. Mari D, Di Berardino F, Cugno M (2002) Chronic heart failure and the immune system. Clin Rev Allergy Immunol 23: 325-340. [Crossref]

284. Ruvolo G, Pisano C, Candore G, Lio D, Palmeri C, et al. (2014) Can the TLR-4mediated signaling pathway be "a key inflammatory promoter for sporadic TAA"? Mediators Inflamm 2014: 349476. [Crossref]

285. Caforio AL, Tona F, Bottaro S, Vinci A, Dequal G, et al. (2008) Clinical implications of anti-heart autoantibodies in myocarditis and dilated cardiomyopathy. Autoimmunity 41: 35-45. [Crossref]

286. Rivkees SA, Wendler CC (2012) Regulation of cardiovascular development by adenosine and adenosine-mediated embryo protection. Arterioscler Thromb Vasc Biol 32: 851-855. [Crossref]

287. Mastellos DC, Deangelis RA, Lambris JD (2013) Complement-triggered pathways orchestrate regenerative responses throughout phylogenesis. Semin Immunol 25: 2938. [Crossref]

288. Clerico A, Iervasi G, Iascone MR, Manfredi C, Sabatino L, et al. (1995) Evaluation of the endocrine function of the heart in humans: proposal for an integrated approach for the assessment of production, secretion, distribution and degradation of atria natriuretic factor and related peptides. Int J Clin Pharmacol Res 15: 65-86. [Crossref] 
289. Del Ry S, Cabiati M, Clerico A (2014) Natriuretic peptide system and the heart. Front Horm Res 43: 134-143. [Crossref]

290. Hiltunen M, Nieminen T, Kettunen R, Hartikainen S, Sulkava R, et al. (2013) B-type natriuretic peptide and severity of cognitive disorder. Eur J Clin Invest 43: 1171-1177. [Crossref]

291. Chen L, He XZ, Liu QM (2014) Neuroendocrine mechanisms of left ventricular dysfunction stimulated by anger stress in rats with atherosclerosis--a putative role of natriuretic peptide. Asian Pac J Trop Med 7: 48-54. [Crossref]

292. Ueda K, Teragawa H, Kimura M, Matsuda K, Higashi Y, et al. (2005) Adrenomedullin causes coronary vasodilation in humans: effects of inhibition of nitric oxide synthesis. J Cardiovasc Pharmacol 46: 534-539. [Crossref]

293. Jougasaki M, Grantham JA, Redfield MM, Burnett JC Jr (2001) Regulation of cardiac adrenomedullin in heart failure. Peptides 22: 1841-1850. [Crossref]

294. Jougasaki M, Rodeheffer RJ, Redfield MM, Yamamoto K, Wei CM, et al. (1996) Cardiac secretion of adrenomedullin in human heart failure. $J$ Clin Invest 97: 23702376. [Crossref]

295. Jougasaki M, Burnett JC Jr (2001) Continuing insights into the heart as an endocrine organ: adrenomedullin and cardiac fibroblasts. Cardiovasc Res 49: 695-696. [Crossref]

296. Hiley CR (2009) Endocannabinoids and the heart. J Cardiovasc Pharmacol 53: 267 276. [Crossref]

297. Okun E, Griffioen KJ, Rothman S, Wan R, Cong WN, et al. (2014) Toll-like receptors 2 and 4 modulate autonomic control of heart rate and energy metabolism. Brain Behav Immun 36: 90-100. [Crossref]

298. McCarthy CG, Goulopoulou S, Wenceslau CF, Spitler K, Matsumoto T, et al. (2014) Toll-like receptors and damage-associated molecular patterns: novel links between inflammation and hypertension. Am J Physiol Heart Circ Physiol 306: H184-H196. [Crossref]

299. Van Linthout S, Miteva K, Tschöpe C (2014) Crosstalk between fibroblasts and inflammatory cells. Cardiovasc Res 102: 258-269. [Crossref]

300. Ross R (1999) Atherosclerosis--an inflammatory disease. N Engl J Med 340: 115-126. [Crossref]

301. Rader DJ, Daugherty A (2008) Translating molecular discoveries into new therapies for atherosclerosis. Nature 451: 904-913. [Crossref]

302. Li L, Huang X, Jia Z, Wu Y, Zheng Q (2009) Evaluation of the impacts of homocysteine and hypoxia on vascular endothelial function based on the profiling of neuro-endocrine-immunity network in rats. Pharmacol Res 60: 277-283. [Crossref]

303. Li L, Jia Z, Xu L, Wu Y, Zheng Q (2014) Expression profile of neuro-endocrineimmune network in rats with vascular endothelial dysfunction. Korean $J$ Physiol Pharmacol 18: 177-182. [Crossref]

304. Yuan GQ, Jia ZH, Yang HT, Wu SZ, Gao HL, et al. (2010) Comfortable lifestyleinduced imbalance of neuro-endocrine-immunity network: A possible mechanism of vascular endothelial dysfunction. Chin J Integr Med 16: 54-60. [Crossref]

305. Anderson JL, Vanwoerkom RC, Horne BD, Bair TL, May HT, et al. (2011) Parathyroid hormone, vitamin $\mathrm{D}$, renal dysfunction, and cardiovascular disease: dependent or independent risk factors? Am Heart J 162: 331-339. [Crossref]

306. Davel AP, Wenceslau CF, Akamine EH, Xavier FE, Couto GK, et al. (2011) Endothelial dysfunction in cardiovascular and endocrine-metabolic diseases: an update. Braz J Med Biol Res 44: 920-932. [Crossref]

307. Savinova OV, Liu Y, Aasen GA, Mao K, Weltman NY, et al. (2011) Thyroid hormone promotes remodeling of coronary resistance vessels. PLoS One 6: e25054. [Crossref]

308. Traub-Weidinger T, Graf S, Beheshti M, Ofluoglu S, Zettinig G, et al. (2012) Coronary vasoreactivity in subjects with thyroid autoimmunity and subclinical hypothyroidism before and after supplementation with thyroxine. Thyroid 22: 245-251. [Crossref]

309. Bozhko AP, Solodkov AP (1990). The effect of thyroid hormones on the stress-induced changes in the coronary blood flow and contractile function of the hypertrophied heart. Fiziol Zh SSSR Im I M Sechenova 76: 1333-1339. [Crossref]

310. Abdu TA, Elhadd T, Pfeifer M, Clayton RN (2001) Endothelial dysfunction in endocrine disease. Trends Endocrinol Metab 12: 257-265. [Crossref]

311. Oflaz H, Sen F, Elitok A, Cimen AO, Onur I, et al. (2007) Coronary flow reserve is impaired in patients with adult growth hormone (GH) deficiency. Clin Endocrinol (Oxf) 66: 524-529. [Crossref]
312. Colao A (2008) The GH-IGF-I axis and the cardiovascular system: clinical implications. Clin Endocrinol (Oxf) 69: 347-358. [Crossref]

313. Higashi Y, Sukhanov S, Anwar A, Shai SY, Delafontaine P (2012) Aging, atherosclerosis, and IGF-1. J Gerontol A Biol Sci Med Sci 67: 626-639. [Crossref]

314. Fallo F, Famoso G, Capizzi D, Sonino N, Dassie F, et al. (2013) Coronary microvascular function in patients with Cushing's syndrome. Endocrine 43: 206-213. [Crossref]

315. van den Berg TN, Rongen GA, Fröhlich GM, Deinum J, Hausenloy DJ, et al. (2014) The cardioprotective effects of mineralocorticoid receptor antagonists. Pharmacol Ther 142: 72-87. [Crossref]

316. Caretta N, Feltrin G, Tarantini G, D'Agostino C, Tona F, et al. (2013) Erectile dysfunction, penile atherosclerosis, and coronary artery vasculopathy in heart transplant recipients. J Sex Med 10: 2295-2302. [Crossref]

317. Fujimoto K, Hozumi T, Watanabe H, Tokai K, Shimada K, et al. (2006) Acute hyperglycemia induced by oral glucose loading suppresses coronary microcirculation on transthoracic Doppler echocardiography in healthy young adults. Echocardiography 23: 829-834. [Crossref]

318. Sundell J, Nuutila P, Laine H, Luotolahti M, Kalliokoski K, et al. (2002) Dosedependent vasodilating effects of insulin on adenosine-stimulated myocardial blood flow. Diabetes 51: 1125-1130. [Crossref]

319. Lautamäki R, Airaksinen KE, Seppänen M, Toikka J, Härkönen R, et al. (2006) Insulin improves myocardial blood flow in patients with type 2 diabetes and coronary artery disease. Diabetes 55: 511-516. [Crossref]

320. Sundell J, Knuuti J (2003) Insulin and myocardial blood flow. Cardiovasc Res 57 : 312-319. [Crossref]

321. Spiroglou SG, Kostopoulos CG, Varakis JN, Papadaki HH (2010) Adipokines in periaortic and epicardial adipose tissue: differential expression and relation to atherosclerosis. J Atheroscler Thromb 17: 115-130. [Crossref]

322. Osto E, Doytcheva P, Corteville C, Bueter M, Dörig C, et al. (2015) Rapid and Body Weight-Independent Improvement of Endothelial and HDL Function After Rouxen-Y Gastric Bypass: Role of Glucagon-Like Peptide-1. Circulation 131: 871-881. [Crossref]

323. Tona F, Serra R, Di Ascenzo L, Osto E, Scarda A, et al. (2014) Systemic inflammation is related to coronary microvascular dysfunction in obese patients without obstructive coronary disease. Nutr Metab Cardiovasc Dis 24: 447-453. [Crossref]

324. Gutkowska J, Jankowski M (2012) Oxytocin revisited: its role in cardiovascular regulation. J Neuroendocrinol 24: 599-608. [Crossref]

325. Danalache BA, Yu C, Gutkowska J, Jankowski M (2014) Oxytocin-Gly-Lys-Arg stimulates cardiomyogenesis by targeting cardiac side population cells. J Endocrinol 220: 277-289. [Crossref]

326. Holmes CL, Landry DW, Granton JT (2003) Science review: Vasopressin and the cardiovascular system part 1--receptor physiology. Crit Care 7: 427-434. [Crossref]

327. Gutkowska J, Jankowski M, Antunes-Rodrigues J2 (2014) The role of oxytocin in cardiovascular regulation. Braz J Med Biol Res 47: 206-214. [Crossref]

328. Holmes CL, Landry DW, Granton JT (2004) Science Review: Vasopressin and the cardiovascular system part 2 - clinical physiology. Crit Care 8: 15-23. [Crossref]

329. Japundžić-Žigon N (2013) Vasopressin and oxytocin in control of the cardiovascular system. Curr Neuropharmacol 11: 218-230. [Crossref]

330. Parissis JT, Farmakis D, Fountoulaki K, Rigas A, Nikolaou M, et al. (2013) Clinica and neurohormonal correlates and prognostic value of serum prolactin levels in patients with chronic heart failure. Eur J Heart Fail 15: 1122-1130. [Crossref]

331. Jiang XB, Li CL, He DS, Mao ZG, Liu DH, et al. (2014) Increased carotid intima media thickness is associated with prolactin levels in subjects with untreated prolactinoma: a pilot study. Pituitary 17: 232-239. [Crossref]

332. Clapp C, Thebault S, Macotela Y, Moreno-Carranza B, Triebel J, et al. (2015) Regulation of blood vessels by prolactin and vasoinhibins. Adv Exp Med Biol 846: 83-95. [Crossref]

333. Molinari C, Grossini E, Mary DASG, Uberti F, Ghigo E, et al. (2007) Prolactin induces regional vasoconstriction through the beta2-adrenergic and nitric oxide mechanisms. Endocrinology 148: 4080-4090. [Crossref]

334. Reiter RJ, Tan DX, Terron MP, Flores LJ, Czarnocki Z (2007) Melatonin and its metabolites: new findings regarding their production and their radical scavenging actions. Acta Biochim Pol 54: 1-9. [Crossref] 
335. Cos S, Alvarez-García V, González A, Alonso-González C, Martínez-Campa C (2014) Melatonin modulation of crosstalk among malignant epithelial, endothelial and adipose cells in breast cancer (Review). Oncol Lett 8: 487-492. [Crossref]

336. Reiter RJ, Calvo JR, Karbownik M, Qi W, Tan DX (2000) Melatonin and its relation to the immune system and inflammation. Ann N Y Acad Sci 917: 376-386. [Crossref]

337. Tare M, Parkington HC, Wallace EM, Sutherland AE, Lim R, et al. (2014) Maternal melatonin administration mitigates coronary stiffness and endothelial dysfunction, and improves heart resilience to insult in growth restricted lambs. J Physiol 592: 2695709. [Crossref]

338. Dutra FF, Bozza MT (2014) Heme on innate immunity and inflammation. Front Pharmacol 5: 115. [Crossref]

339. Zhu X, Fan WG, Li DP, Kung H, Lin MC (2011) Heme oxygenase-1 system and gastrointestinal inflammation: a short review. World J Gastroenterol 17: 4283-4288. [Crossref]

340. Deetman PE, Bakker SJ, Dullaart RP (2013) High sensitive C-reactive protein and serum amyloid A are inversely related to serum bilirubin: effect-modification by metabolic syndrome. Cardiovasc Diabetol 12: 166. [Crossref]

341. Çiftçi O, Güllü H, Günday M, Çaliskan M, Kulaksizoglu S, et al. (2013) Association between serum ?-glutamyltransferase levels and coronary microvascular function. Coron Artery Dis24: 201-8. [Crossref]

342. Fragala MS, Kraemer WJ, Denegar CR, Maresh CM, Mastro AM, et al. (2011) Neuroendocrine-immune interactions and responses to exercise. Sports Med 41: 621639. [Crossref]

343. Osto E, Piaserico S, Maddalozzo A, Forchetti G, Montisci R, et al. (2012) Impaired coronary flow reserve in young patients affected by severe psoriasis. Atherosclerosis 221: 113-117. [Crossref]

344. Pober JS, Sessa WC (2007) Evolving functions of endothelial cells in inflammation. Nat Rev Immunol 7: 803-815.

345. Tellides G, Pober JS2 (2015) Inflammatory and immune responses in the arterial media. Circ Res 116: 312-322. [Crossref]

346. Kuusisto J, Kärjä V, Sipola P, Kholová I, Peuhkurinen K, et al. (2012) Low-grade inflammation and the phenotypic expression of myocardial fibrosis in hypertrophic cardiomyopathy. Heart 98: 1007-1013. [Crossref]

347. Dias P, Joshi M (2012) Endothelial dysfunction as a risk factor for cardiovascular disease; its modulation by phyto-ingredients and implication in better cardiovascular health. Oxid Antioxid Med Sci 1: 1.

348. Alie N, Eldib M, Fayad ZA, Mani V (2015) Inflammation, Atherosclerosis, and Coronary Artery Disease: PET/CT for the Evaluation of Atherosclerosis and Inflammation. Clin Med Insights Cardiol 8: 13-21. [Crossref]

349. Sacks HS, Fain JN (2007) Human epicardial adipose tissue: a review. Am Heart J153: 907-917. [Crossref]

350. van Bilsen M, Planavila A (2014) Fatty acids and cardiac disease: fuel carrying a message. Acta Physiol (Oxf) 211: 476-490. [Crossref]

351. Montecucco F, Di Marzo V (2012) At the heart of the matter: the endocannabinoid system in cardiovascular function and dysfunction. Trends Pharmacol Sci 33: 331340. [Crossref]

352. D'Addario C, Di Francesco A, Pucci M, Finazzi Agrò A, Maccarrone M (2013) Epigenetic mechanisms and endocannabinoid signalling. FEBS J 280: 1905-1917. [Crossref]

353. O'Sullivan SE, Kendall PJ, Kendall DA (2012) Endocannabinoids and the cardiovascular response to stress. J Psychopharmacol 26: 71-82. [Crossref]

354. Stanley C, O'Sullivan SE (2014) Vascular targets for cannabinoids: animal and human studies. Br J Pharmacol 171: 1361-1378. [Crossref]

355. Cappellano G, Uberti F, Caimmi PP, Pietronave S, Mary DA, et al. (2013) Different expression and function of the endocannabinoid system in human epicardial adipose tissue in relation to heart disease. Can J Cardiol 29: 499-509. [Crossref]

356. Snider NT, Walker VJ, Hollenberg PF (2010) Oxidation of the endogenous cannabinoid arachidonoyl ethanolamide by the cytochrome P450 monooxygenases: physiological and pharmacological implications. Pharmacol Rev 62: 136-154. [Crossref]

357. Ugdyzhekova DS, Bernatskaya NA, Stefano JB, Graier VF, Tam SW, et al. (2000) Endogenous cannabinoid anandamide increases heart resistance to arrhythmogenic effects of epinephrine: Role of CB 1 and CB 2 receptors. Bull Exp Biol Med 131: 251-253.
358. Al Kury LT, Yang KH, Thayyullathil FT, Rajesh M, Ali RM, et al. (2014) Effects of endogenous cannabinoid anandamide on cardiac $\mathrm{Na}^{+} / \mathrm{Ca}^{2+}$ exchanger. Cell Calcium 55: 231-237. [Crossref]

359. Duerr GD, Heinemann JC, Suchan G, Kolobara E, Wenzel D, et al. (2014) The endocannabinoid-CB2 receptor axis protects the ischemic heart at the early stage of cardiomyopathy. Basic Res Cardiol 109: 425. [Crossref]

360. Kaufmann I, Schelling G, Eisner C, Richter HP, Krauseneck T, et al. (2008) Anandamide and neutrophil function in patients with fibromyalgia. Psychoneuroendocrinology 33 : 676-685. [Crossref]

361. De Laurentiis A, Araujo HA, Rettori V (2014) Role of the endocannabinoid system in the neuroendocrine responses to inflammation. Curr Pharm Des 20: 4697-4706. [Crossref]

362. Jackson AR, Nagarkatti P, Nagarkatti M (2014) Anandamide attenuates Th-17 cellmediated delayed-type hypersensitivity response by triggering IL-10 production and consequent microRNA induction. PLoS One 9: e93954. [Crossref]

363. Nicolaou A, Mauro C, Urquhart P, Marelli-Berg F (2014) Polyunsaturated Fatty Acidderived lipid mediators and T cell function. Front Immunol 5: 75. [Crossref]

364. Pacher P, Kunos G (2013) Modulating the endocannabinoid system in human health and disease--successes and failures. FEBS J 280: 1918-1943. [Crossref]

365. Pacher P, Bátkai S, Kunos G (2006) The endocannabinoid system as an emerging target of pharmacotherapy. Pharmacol Rev 58: 389-462. [Crossref]

366. Liu J, Wang L, Harvey-White J, Osei-Hyiaman D, Razdan R, et al. (2006) A biosynthetic pathway for anandamide. Proc Natl Acad Sci U S A 103: 13345-13350. [Crossref]

367. Baranowska-Kuczko M, Kozlowska H, Kozlowski M, Schlicker E, Kloza M, et al. (2000) Mechanisms of endothelium-dependent relaxation evoked by anandamide in isolated human pulmonary arteries. Naunyn Schmiedebergs Arch Pharmacol 387 477-486. [Crossref]

368. Stefano GB, Esch T, Cadet P, Zhu W, Mantione K, et al. (2003) Endocannabinoids as autoregulatory signaling molecules: coupling to nitric oxide and a possible association with the relaxation response. Med Sci Monit 9: RA63-75. [Crossref]

369. Vallance P, Collier J, Moncada S (1989) Effects of endothelium-derived nitric oxide on peripheral arteriolar tone in man. Lancet 2: 997-1000. [Crossref]

370. Halcox JP, Schenke WH, Zalos G, Mincemoyer R, Prasad A, et al. (2002) Prognostic value of coronary vascular endothelial dysfunction. Circulation 106: 653-658. [Crossref]

371. Toda N, Okamura T (2003) The pharmacology of nitric oxide in the periphera nervous system of blood vessels. Pharmacol Rev 55: 271-324. [Crossref]

372. Seddon M, Melikian N, Dworakowski R, Shabeeh H, Jiang B, et al. (2009) Effects of neuronal nitric oxide synthase on human coronary artery diameter and blood flow in vivo. Circulation 119: 2656-2662. [Crossref]

373. Seddon MD, Chowienczyk PJ, Brett SE, Casadei B, Shah AM (2008) Neuronal nitric oxide synthase regulates basal microvascular tone in humans in vivo. Circulation 117 1991-1996. [Crossref]

374. Erickson MA, Dohi K, Banks WA (2012) Neuroinflammation: a common pathway in CNS diseases as mediated at the blood-brain barrier. Neuroimmunomodulation 19 121-130. [Crossref]

375. Gárate I, Garcia-Bueno B, Madrigal JL, Caso JR, Alou L, et al. (2013) Stress-induced neuroinflammation: role of the Toll-like receptor-4 pathway. Biol Psychiatry 73: 3243. [Crossref]

376. Jara LJ, Navarro C, Medina G, Vera-Lastra O, Blanco F (2006) Immuneneuroendocrine interactions and autoimmune diseases. Clin Dev Immunol 13: 109123. [Crossref]

377. Kohman RA, Rhodes JS (2013) Neurogenesis, inflammation and behavior. Brain BehavImmun 27: 22-32. [Crossref]

378. Watkins LR, Hutchinson MR, Milligan ED, Maier SF (2007) "Listening” and "talking” to neurons: implications of immune activation for pain control and increasing the efficacy of opioids. Brain Res Rev 56: 148-169. [Crossref]

379. Nance DM, Sanders VM (2007) Autonomic innervation and regulation of the immune system (1987-2007). Brain Behav Immun 21: 736-745. [Crossref]

380. Denef C (2008) Paracrinicity: the story of 30 years of cellular pituitary crosstalk. $J$ Neuroendocrinol 20: 1-70. [Crossref] 
381. Bugajski J, Gadek-Michalska A, Bugajski AJ (2004) Nitric oxide and prostaglandin systems in the stimulation of hypothalamic-pituitary-adrenal axis by neurotransmitters and neurohormones. J Physiol Pharmacol 55: 679-703. [Crossref]

382. Gądek-Michalska A, Tadeusz J, Rachwalska P, Bugajski J (2013) Cytokines, prostaglandins and nitric oxide in the regulation of stress-response systems. Pharmacol Rep 65: 1655-1662. [Crossref]

383. Katoh S, Honda S, Watanabe T, Suzuki S, Ishino M, et al. (2014) Atrial endothelial impairment through Toll-like receptor 4 signaling causes atrial thrombogenesis. Heart Vessels 29: 263-272. [Crossref]

384. Ashida K, Miyazaki K, Takayama E, Tsujimoto H, Ayaori M, et al. (2005) Characterization of the expression of TLR2 (toll-like receptor 2) and TLR4 on circulating monocytes in coronary artery disease. $J$ Atheroscler Thromb12: 53-60. [Crossref]

385. Satoh M, Ishikawa Y, Minami Y, Takahashi Y, Nakamura M (2008) Role of Toll like receptor signaling pathway in ischemic coronary artery disease. Front Biosci 13: 6708-6715. [Crossref]

386. Versteeg D, Hoefer IE, Schoneveld AH, de Kleijn DP V, et al. (2002) Monocyte toll-like receptor 2 and 4 responses and expression following percutaneous coronary intervention: association with lesion stenosis and fractional flow reserve. Heart 94 : 770-6. [Crossref]

387. Vetreno RP, Crews FT (2012) Adolescent binge drinking increases expression of the danger signal receptor agonist HMGB1 and Toll-like receptors in the adult prefrontal cortex. Neuroscience 226: 475-488. [Crossref]

388. Coleman LG Jr, He J, Lee J, Styner M, Crews FT (2011) Adolescent binge drinking alters adult brain neurotransmitter gene expression, behavior, brain regional volumes, and neurochemistry in mice. Alcohol Clin Exp Res 35: 671-688. [Crossref]

389. Yin Y, Hou G, Li E, Wang Q, Kang J. Regulation of cigarette smoke-induced toll-like receptor 4 expression by peroxisome proliferator-activated receptor-gamma agonists in bronchial epithelial cells. Respirology18 Suppl 3: 30-39. [Crossref]

390. Leon DA, Shkolnikov VM, McKee M, Kiryanov N, Andreev E (2010) Alcohol increases circulatory disease mortality in Russia: acute and chronic effects or misattribution of cause? Int J Epidemiol 39: 1279-1290. [Crossref]

391. Davidson DM (1989) Cardiovascular effects of alcohol. West J Med 151: 430-439. [Crossref]

392. Benowitz NL, Jones RT, Jacob P 3rd (1986) Additive cardiovascular effects of nicotine and ethanol. Clin Pharmacol Ther 40: 420-424. [Crossref]

393. Middlekauff HR, Park J, Moheimani RS (2014) Adverse effects of cigarette and noncigarette smoke exposure on the autonomic nervous system: mechanisms and implications for cardiovascular risk. J Am Coll Cardiol 64: 1740-1750. [Crossref]

394. Durazzo TC, Gazdzinski S, Meyerhoff DJ (2007) The neurobiological and neurocognitive consequences of chronic cigarette smoking in alcohol use disorders. Alcohol Alcohol 42: 174-185. [Crossref]

395. Grassi D, Desideri G, Ferri L, Aggio A, Tiberti S, et al. (2010) Oxidative stress and endothelial dysfunction: say NO to cigarette smoking! Curr Pharm Des 16: 25392550. [Crossref]

396. Oliver JA, Blank MD, Van Rensburg KJ, MacQueen DA, Brandon TH, et al. (2015) Nicotine interactions with low-dose alcohol: pharmacological influences on smoking and drinking motivation. J Abnorm Psychol 122: 1154-1165. [Crossref]

397. Maes M (2011) Depression is an inflammatory disease, but cell-mediated immune activation is the key component of depression. Prog Neuropsychopharmacol Biol Psychiatry 35: 664-675. [Crossref]

398. Jones MR, Barnoya J, Stranges S, Losonczy L, Navas-Acien A (2014) Cardiovascular Events Following Smoke-Free Legislations: An Updated Systematic Review and Meta-Analysis. Curr Environ Health Rep 1: 239-249. [Crossref]

399. Bottaccioli F (2014) Epigenetica e psiconeuroendocrinoimmunologia. 1st ed. Milano: Edra editore.

400. Bierhaus A, Wolf J, Andrassy M, Rohleder N, Humpert PM, et al. (2003) A mechanism converting psychosocial stress into mononuclear cell activation. Proc Natl Acad Sci U S A 100: 1920-1925. [Crossref] Hermus AR, Sweep CG (1990) Cytokines and the hypothalamic-pituitary-adrenal axis. J Steroid Biochem Mol Biol 37: 867-871. [Crossref]

401. Hermus AR, Sweep CG (1990) Cytokines and the hypothalamic-pituitary-adrenal axis. J Steroid Biochem Mol Biol 37: 867-871. [Crossref]

402. Harbuz MS, Stephanou A, Sarlis N, Lightman SL (1992) The effects of recombinant human interleukin (IL)-1 alpha, IL-1 beta or IL-6 on hypothalamo-pituitary-adrenal axis activation. $J$ Endocrinol 133: 349-355. [Crossref]

403. Nolten WE, Goldstein D, Lindstrom M, McKenna MV, Carlson IH, et al. (1993) Effects of cytokines on the pituitary-adrenal axis in cancer patients. J Interferon Res 13: 349-357. [Crossref]

404. Kim DS, Melmed S (1999) Stimulatory effect of leukemia inhibitory factor on ACTH secretion of dispersed rat pituitary cells. Endocr Res 25: 11-19. [Crossref]

405. Ader R (2001) Psychoneuroimmunology. Curr Dir Psychol Sci 10: 94-8.

406. Ader R, Felten D, Cohen N (1990) Interactions between the brain and the immune system. Annu Rev Pharmacol Toxicol 30: 561-602. [Crossref]

407. Woloski BM, Smith EM, Meyer WJ 3rd, Fuller GM, Blalock JE (1985) Corticotropinreleasing activity of monokines. Science 230: 1035-1037. [Crossref]

408. Schneider H, Pitossi F, Balschun D, Wagner A, del Rey A, et al. (1998) A neuromodulatory role of interleukin-1beta in the hippocampus. Proc Natl Acad Sci U $S$ A 95: 7778-7783. [Crossref]

409. Karanth S, McCann SM (1991) Anterior pituitary hormone control by interleukin 2 . Proc Natl Acad Sci U S A 88: 2961-2965. [Crossref]

410. Chen HF, Jeung EB, Stephenson M, Leung PC (1999) Human peripheral blood mononuclear cells express gonadotropin-releasing hormone (GnRH), GnRH receptor, and interleukin-2 receptor gamma-chain messenger ribonucleic acids that are regulated by GnRH in vitro. J Clin Endocrinol Metab 84: 743-50. [Crossref]

411. Withyachumnarnkul B, Reiter RJ, Lerchl A, Nonaka KO, Stokkan KA (1991) Evidence that interferon-gamma alters pineal metabolism both indirectly via sympathetic nerves and directly on the pinealocytes. Int J Biochem 23: 1397-1401. [Crossref]

412. Zylinska K, Komorowski J, Robak T, Mucha S, Stepien H (1995) Effect of granulocytemacrophage colony stimulating factor and granulocyte colony stimulating factor on melatonin secretion in rats in vivo and in vitro studies. J Neuroimmunol 56: 187-90. [Crossref]

413. Salkowski CA, Vogel SN (1992) IFN-gamma mediates increased glucocorticoid receptor expression in murine macrophages. J Immunol 148: 2770-2777. [Crossref]

414. Ando T, Dunn AJ (1999) Mouse tumor necrosis factor-alpha increases brain tryptophan concentrations and norepinephrine metabolism while activating the HPA axis in mice. Neuroimmunomodulation 6: 319-329. [Crossref]

415. Barkhudaryan N, Dunn AJ (1999) Molecular mechanisms of actions of interleukin-6 on the brain, with special reference to serotonin and the hypothalamo-pituitaryadrenocortical axis. Neurochem Res 24: 1169-1180. [Crossref]

416. Black PH (2003) The inflammatory response is an integral part of the stress response: Implications for atherosclerosis, insulin resistance, type II diabetes and metabolic syndrome X. Brain Behav Immun 17: 350-64. [Crossref]

417. Smith EM, Cadet P, Stefano GB, Opp MR, Hughes TK Jr (1999) IL-10 as a mediator in the HPA axis and brain. J Neuroimmunol 100: 140-148. [Crossref]

418. ZyliÅ,,ska K, Mucha S, Komorowski J, Korycka A, Pisarek H, et al. (1999) Influence of granulocyte-macrophage colony stimulating factor on pituitary-adrenal axis (PAA) in rats in vivo. Pituitary 2: 211-216. [Crossref]

419. Rosa AC, Fantozzi R (2013) The role of histamine in neurogenic inflammation. $B r J$ Pharmacol 170: 38-45. [Crossref]

420. Petrovsky N (2001) Towards a unified model of neuroendocrine-immune interaction Immunol Cell Biol 79: 350-357. [Crossref]

421. Bucala R (1996) MIF rediscovered: cytokine, pituitary hormone, and glucocorticoidinduced regulator of the immune response. FASEB J 10: 1607-1613. [Crossref]

422. Chikanza IC, Petrou P, Chrousos G (2000) Perturbations of arginine vasopressin secretion during inflammatory stress. Pathophysiologic implications. Ann N Y Acad Sci 917: 825-834. [Crossref]

423. Nishino T, Bernhagen J, Shiiki H, Calandra T, Dohi K (1995) Localization of macrophage migration inhibitory factor (MIF) to secretory granules within the corticotrophic and thyrotrophic cells of the pituitary gland. Mol Med 1: 781-788. [Crossref]

424. Sacerdote P, Gaspani L, Panerai AE (2000) The opioid antagonist naloxone induces a shift from type 2 to type 1 cytokine pattern in normal and skin-grafted mice. Ann NY Acad Sci 917: 755-763. [Crossref]

425. Guarini S, Altavilla D, Cainazzo M-M, Giuliani D, Bigiani A, et al. (2003) Efferen 
vagal fibre stimulation blunts nuclear factor-kappaB activation and protects against hypovolemic hemorrhagic shock. Circulation 107: 1189-94. [Crossref]

426. Latendresse G, Ruiz RJ (2011) Maternal Corticotropin-Releasing Hormone and the Use of Selective Serotonin Reuptake Inhibitors Independently Predict the Occurrence of Preterm Birth. J Midwifery Women's Heal 56: 118-26. [Crossref]

427. Ackerman JP, Riggins T, Black MM (2010) A review of the effects of prenatal cocaine exposure among school-aged children. Pediatrics 125: 554-565. [Crossref]

428. Chapman BP, Moynihan J (2009) The brain-skin connection: role of psychosocial factors and neuropeptides in psoriasis. Expert Rev Clin Immunol 5: 623-627. [Crossref]

429. Ramírez F, Fowell DJ, Puklavec M, Simmonds S, Mason D (1996) Glucocorticoids promote a TH2 cytokine response by CD4+ T cells in vitro. J Immunol 156: 24062412. [Crossref]

430. Dhabhar FS, McEwen BS (1996) Stress-induced enhancement of antigen-specific cellmediated immunity. J Immunol 156: 2608-2615. [Crossref]

431. Tolosa E, Ashwell JD (1999) Thymus-derived glucocorticoids and the regulation of antigen-specific T-cell development. Neuroimmunomodulation 6: 90-96. [Crossref]

432. Petrovsky N, McNair P, Harrison LC (1998) Diurnal rhythms of pro-inflammatory cytokines: regulation by plasma cortisol and therapeutic implications. Cytokine 10: 307-312. [Crossref]

433. Brinkmann V, Kristofic C (1995) Regulation by corticosteroids of Th1 and Th2 cytokine production in human CD4+ effector T cells generated from CD45RO- and CD45RO+ subsets. J Immunol 155: 3322-3328. [Crossref]

434. Catania A, Cutuli M, Garofalo L, Carlin A, Airaghi L, et al. (2000) The neuropeptide alpha-MSH in host defense. Ann N Y Acad Sci 917: 227-231. [Crossref]

435. Matera L, Mori M (2000) Cooperation of pituitary hormone prolactin with interleukin- 2 and interleukin-12 on production of interferon-gamma by natural killer and T cells. Ann N Y Acad Sci 917: 505-513. [Crossref]

436. Reiter RJ, Tan DX, Fuentes-Broto L (2010) Melatonin: a multitasking molecule. Prog Brain Res 181: 127-151. [Crossref]

437. Sze SF, Liu WK, Ng TB (1993) Stimulation of murine splenocytes by melatonin and methoxytryptamine. J Neural Transm Gen Sect 94: 115-126. [Crossref]

438. Colombo LL, Chen GJ, Lopez MC, Watson RR (1992) Melatonin induced increase in gamma-interferon production by murine splenocytes. Immunol Lett 33: 123-126. [Crossref]

439. García-Mauriño S, Pozo D, Carrillo-Vico A, Calvo JR, Guerrero JM (1999) Melatonin activates Th1 lymphocytes by increasing IL-12 production. Life Sci 65: 2143-2150. [Crossref]

440. Jirapongsananuruk O, Melamed I, Leung DY (2000) Additive immunosuppressive effects of ,25-dihydroxyvitamin D3 and corticosteroids on $\mathrm{TH}$, but not $\mathrm{TH} 2$, responses. J Allergy Clin Immunol 106: 981-985. [Crossref]

441. Sugama S, Kim Y, Baker H, Tinti C, Kim H, et al. (2000) Tissue-specific expression of rat IL-18 gene and response to adrenocorticotropic hormone treatment. J Immunol 165: 6287-6292. [Crossref]

442. Piccinni MP, Giudizi MG, Biagiotti R, Beloni L, Giannarini L, et al. (1995) Progesterone favors the development of human $\mathrm{T}$ helper cells producing Th2-type cytokines and promotes both IL-4 production and membrane CD30 expression in established Th1 cell clones. J Immunol 155: 128-133. [Crossref]

443. Camici PG, Crea F (2007) Coronary microvascular dysfunction. $N$ Engl J Med 356: 830-840. [Crossref]

444. Miura H, Wachtel RE, Liu Y, Loberiza FR Jr, Saito T, et al. (2001) Flow-induced dilation of human coronary arterioles: important role of $\mathrm{Ca}(2+)$-activated $\mathrm{K}(+)$ channels. Circulation 103: 1992-1998. [Crossref]
445. Duncker DJ, Koller A, Merkus D, Canty JM Jr (2015) Regulation of coronary blood flow in health and ischemic heart disease. Prog Cardiovasc Dis 57: 409-422. [Crossref]

446. Tune JD, Richmond KN, Gorman MW, Feigl EO (2002) Control of coronary blood flow during exercise. Exp Biol Med (Maywood) 227: 238-250. [Crossref]

447. Longmore M, Wilkinson I, Baldwin A, Wallin E. Oxford Handbook of Clinical Medicine. 9th ed. new York: Oxford University Press, 2014: 225.

448. Armour JA (2007) The little brain on the heart. Cleve Clin J Med 74 Suppl 1: S48-51. [Crossref]

449. Armour JA (2008) Potential clinical relevance of the 'little brain' on the mammalian heart. Exp Physiol 93: 165-176. [Crossref]

450. Kember G, Armour JA, Zamir M (2013) Neural control hierarchy of the heart has not evolved to deal with myocardial ischemia. Physiol Genomics 45: 638-644. [Crossref]

451. Bairey CN, Krantz DS, DeQuattro V, Berman DS, Rozanski A (1991) Effect of betablockade on low heart rate-related ischemia during mental stress. J Am Coll Cardiol 17: 1388-1395. [Crossref]

452. Skinner JE (1993) Neurocardiology. Brain mechanisms underlying fatal cardiac arrhythmias. Neurol Clin 11: 325-351. [Crossref]

453. Szczepanska-Sadowska E, Cudnoch-Jedrzejewska A, Ufnal M, Zera T (2010) Brain and cardiovascular diseases: Common neurogenic background of cardiovascular, metabolic and inflammatory diseases. J Physiol Pharmacol 61: 509-562. [Crossref]

454. Manev H (2009) Hypotheses on mechanisms linking cardiovascular and psychiatric neurological disorders. Cardiovasc Psychiatry Neurol 2009: 197132. [Crossref]

455. Francis J, Wei SG, Weiss RM, Felder RB (2004) Brain angiotensin-converting enzyme activity and autonomic regulation in heart failure. Am J Physiol Heart Circ Physiol 287: H2138-2146. [Crossref]

456. Jain S, Goldstein DS (2012) Cardiovascular dysautonomia in Parkinson disease: from pathophysiology to pathogenesis. Neurobiol Dis 46: 572-580. [Crossref]

457. Liou LM, Ruge D, Kuo MC, Tsai JC, Lin CW, et al. (2014) Functional connectivity between parietal cortex and the cardiac autonomic system in uremics. Kaohsiung $J$ Med Sci 30: 125-132. [Crossref]

458. Duncker D, Friedel K, König T, Schreyer H, Lüsebrink U, et al (2015) Cardiac resynchronization therapy improves psycho-cognitive performance in patients with heart failure. Europace [Crossref]

459. Kerr G, Ray G, Wu O, Stott DJ, Langhorne P (2009) Elevated troponin after stroke: a systematic review. Cerebrovasc Dis 28: 220-226. [Crossref]

460. Jaguszewski M, Osipova J, Ghadri J-R, Napp LC, Widera C, et al (2014) A signature of circulating microRNAs differentiates takotsubo cardiomyopathy from acute myocardial infarction. Eur Heart J 35: 999-1006. [Crossref]

461. Steptoe A, Kivimäki M (2012) Stress and cardiovascular disease. Nat Rev Cardiol 9 360-370. [Crossref]

462. Taggart P, Sutton P, Redfern C, Batchvarov VN, Hnatkova K, et al. (2005) The effect of mental stress on the non-dipolar components of the $\mathrm{T}$ wave: modulation by hypnosis. Psychosom Med 67: 376-383. [Crossref]

463. Taggart P, Critchley H, Lambiase PD (2011) Heart-brain interactions in cardiac arrhythmia. Heart 97: 698-708 [Crossref]

464. Mostofsky E, Penner EA, Mittleman MA (2014) Outbursts of anger as a trigger of acute cardiovascular events: a systematic review and meta-analysis. Eur Heart $J 35$ : 1404-1410 [Crossref]

465. Mostofsky E, Maclure M, Tofler GH, Muller JE, Mittleman MA (2013) Relation of outbursts of anger and risk of acute myocardial infarction. Am J Cardiol 112: 343-348. [Crossref]

Copyright: C2015 Dal Lin. This is an open-access article distributed under the terms of the Creative Commons Attribution License, which permits unrestricted use, distribution, and reproduction in any medium, provided the original author and source are credited. 